\title{
The Rise Predicts the Fall: How the Method of Leader Entry Affects the Method of Leader Removal in Dictatorships*
}

\author{
Jun Koga SudDuTH ${ }^{\dagger}$ \\ University of Strathclyde
}

CURTIS BELL

One Earth Future Foundation

\begin{abstract}
How does the way a non-democratic leader takes power affect the stability of her government? Prior research identifies irregular leader entries-those violating the regime's norms for leader selection - to be especially likely to foreshadow subsequent unconstitutional transitions. This paper shows how some forms of irregular leader entry can actually protect leaders from most threats of forced removal from power. When leaders use a strong and loyal coalition of supporters to overthrow their predecessors and their entire ruling regimes, as they do in successful rebellions, popular uprisings, and major regimechanging coups, they explicitly prove their strength to any potential rivals. These leaders are substantially less likely to be ousted than leaders who take power in ways that do not convey strength so convincingly, such as normal succession and elite reshuffling. We analyze an original dataset of non-democratic leader transitions and show that accounting for the strength demonstrated during a leader's entry to power substantially improves our ability to predict how and when the leader will eventually leave office.
\end{abstract}

\footnotetext{
*NOTE: The data and all computer code necessary to replicate the results and figures in this analysis will be made publicly available at the authors' homepage on publication. $\mathrm{R}$ and Stata 14 were used for all statistical analyses.

${ }^{\dagger}$ Lecturer, University of Strathclyde, School of Government and Public Policy, McCance Building, 16 Richmond Street, Glasgow G1 1QX, UK (jun.koga@strath.ac.uk).

${ }^{*}$ Research Associate, One Earth Future Foundation, 525 Zang Street, Broomfield, CO, USA, 80026 (cbell@oneearthfuture.org).
} 
How does the way a non-democratic leader takes power affect the stability of her government? Previous research shows irregular ${ }^{1}$ transitions can undermine governance by increasing the likelihood of political violence, slowing economic growth, and perpetuating cycles of unconstitutional regime change (Alesina et al., 1996; Barro, 1991; Campos and Nugent, 2002; Chiozza and Goemans, 2011; Collier et al., 2003; Feng, 1997; Fosu, 2002; Gleditsch and Ruggeri, 2010; Goemans, Gleditsch and Chiozza, 2009; Gupta, 1990; Igbal and Zorn, 2008; Jones and Olken, 2005, 2009; Jong-A-Pin, 2009; Londregan and Poole, 1990; Lehoucq and PérezLinán, 2014; Miller, 2012; Thyne et al., 2014). This link between irregular leader change and regime fragility is well-established. Some researchers even approximate a state's capacity to govern with the way its leader claimed power, with regular entries marking strong states and irregular entries defining especially weak ones (Huntington, 1968; Gleditsch and Ruggeri, 2010).

But by amalgamating many different forms of irregular entry, this literature overlooks how more specific transition types can influence the kinds of threats a leader will face during her time in power. Irregular entry is a broad concept that includes significant and disruptive transitions like rebellions and foreign invasions as well as less consequential internal reshuffles and succession disputes. This inclusive concept does not differentiate contentious transitions between rivals within the same ruling clique from transitions that completely oust the ruling elite and overturn the political structures that kept them in power. We draw on work on opposition coordination in dictatorships (Casper and Tyson, 2014; Edmond, 2013; Geddes, 1999; Kuran, 1989; Karklins and Peterson, 1993; Lohmann, 1993; Little, 2015) to argue that we can learn much more about the political consequences of leader entry by disaggregating these irregular transitions into two substantively important types: irregular regime replacement and irregular regime reorganization.

Foundational research on leader survival in dictatorships suggests all non-democratic leaders should be very interested in conveying strength and invulnerability. Doing so convincingly increases one's chances of keeping power, while doing so unconvincingly invites challenges and compels dictators to make concessions, share power, and accept constraints (Boix

\footnotetext{
${ }^{1}$ Goemans, Gleditsch, and Chiozza (2009: 272) define regular leader transitions as those that occur "according to the prevailing rules, provisions, conventions, and norms of the country."
} 
and Svolik, 2013; Svolik, 2009; Magaloni, 2008; Gandhi and Przeworski, 2007; Gandhi, 2008; Smith, 2005). This pressure to appear strong gives rise to a classic signaling problem: all dictators, strong and weak alike, do what they can to appear invulnerable while their challengers must attempt to discern which claims of strength are actually credible. We contend that some leaders prove the strength and loyalty of their supporting coalitions by forcibly overthrowing their predecessors and overhauling their political systems. These forms of irregular regime replacement include successful rebellions, popular uprisings, and major regime-changing coups d'état. In each of these entry types a sufficiently strong coalition accepted considerable risks and costs to install their chosen leader. This credible show-of-strength can deter aspiring rivals from plotting their own attempts to dislodge the new leader from office.

Other forms of irregular leader entry do not convincingly convey the strength of a new leader's coalition of supporters. There is much more ambiguity around leader strength when they enter by irregular regime reorganization, as in reshuffles among the ruling elite, extraordinary appointments during political crises, or unestablished election or selection processes. These leaders may have very strong support underlying their claims to power-and most leaders in this position work very hard to persuade their new constituents of their invulnerabilitybut their claims of strength cannot be as credible as those made by new leaders who proved the strength of their supporting coalitions while forcibly ousting a predecessor's regime. Following regime reorganizations, new leaders can only attempt to persuade potential rivals of their strength with propaganda, public demonstrations, and repression. There is much less ambiguity around the strength of a leader's hold on power when that leader forced her way in with a strong coalition that would presumably rise up to the leader's defense. Below, we estimate nondemocratic leaders who entered office through regime replacement to be three to five times less likely to be forced from power relative to those who entered by irregular regime reorganization.

Non-democratic leaders who take power through irregular regime replacement are unlikely to suffer similar challenges relative to other dictators, but there are two notable caveats to this argument: this stabilizing effect is short-lived and limited to only a few types of threats. Strong supporting coalitions deter challenges that would require a rival to compete with and 
overcome a leader's coalition (i.e. direct confrontation through war, street protests, and other forms of complete regime change), but they may encourage tactics that circumvent direct engagement with a new leader's coalition, such as assassination. Furthermore, political allegiances shift while new leaders consolidate power and develop new alliances. Over time a leader's entry coalition can become decreasingly representative of the support she enjoys in the present. Thus, the more time a leader has been in power, the less reliably her method of entry predicts the threats she will face while in office.

The paper makes three contributions to the literature on political instability in dictatorships. First, the distinction between irregular regime replacement and irregular regime reorganization greatly improves our ability to forecast different threats to non-democratic rulers. Second, the paper introduces new data that describe eleven forms of leader exit and eight forms of leader entry. These data will allow for more nuanced cross-national studies of authoritarian breakdowns and transitions. Finally, we refine the established wisdom about the "coup traps" (Londregan and Poole, 1990; Lehoucq and Pérez-Linán, 2014) and "conflict traps" (Collier et al., 2003) that purportedly condemn dictatorships to long cycles of instability. Some leaders are ensnared in these traps and suffer short-lived and tumultuous tenures, but those who forcefully take power with strong coalitions credibly signal their strength, deter rivals, and earn a short reprieve from these kinds of challenges.

\section{The Argument}

We derive our argument about how specific forms of entry predict the threats leaders will face from four claims. First, a leader's political survival relies upon her ability to maintain a strong supporting coalition, but in non-democracies allegiances are private and therefore prone to misperception. Second, leader entry by forced regime replacement reveals valuable information about the true strength of the leader's coalition, and this information cannot be signaled as convincingly by other forms of entry. Third, political rivals use this information to form their estimates of a leader's coalition strength and their chances of success should they try to seize 
power. And fourth, the value of any information about leader coalition strength to be gleaned from the leader's entry into power depreciates quickly, as does the influence this information has on those looking to challenge the leader.

\section{Political Allegiances and Uncertainty in Non-Democratic States}

Leaders stay in power by maintaining a strong and loyal coalition of supporters (Ames, 1987; Bueno de Mesquita et al., 2003; Chiozza and Goemans, 2011; Svolik, 2012; Sudduth, 2017). Leaders of democracies do this by attracting a bloc of voters that is large enough to defeat rival voting coalitions at the polls. Political competition is less transparent in non-democratic states, but leader coalitions in these systems are typically comprised of adequate shares of the public, the military, and the political elite. ${ }^{2}$ Non-democratic leaders stay in power by ensuring that their coalition remains strong enough to overcome any rival coalitions. They do this by simultaneously incentivizing loyalty among their supporters with private goods provisions while obstructing rivals with repression and the threat or use of political violence (Acemoglu and Robinson, 2006; Bell, 2011; Bueno de Mesquita et al., 2003; Bueno de Mesquita and Smith, 2015; Conrad, 2011; Gandhi and Przeworski, 2007; Svolik, 2008, 2012).

A defining characteristic of non-democratic politics is the absence of regular, transparent, and competitive contests for power that reveal the true size and strength of a leader's coalition of supporters. This is certainly true where there are no elections to allow opposition leaders to vie for power against the incumbent, though it is also true where election results are manipulated so as to obscure a leader's true level of support (Beaulieu and Hyde, 2009; Daxecker, 2014; Levitsky and Way, 2010; González-Ocantos, Kiewiet de Jonge and Nickerson, 2015). Even in the increasing share of non-democratic regimes with multi-party elections, these contests are usually superficial and the results typically favor the incumbent due to outright distortion of the vote tallies or by policies that place challengers at an insurmountable structural disadvantage (Gandhi, 2008; Schedler, 2006, 2013). ${ }^{3}$

\footnotetext{
${ }^{2}$ For more on how a leader's specific sources of support vary in different styles of dictatorship, see, among others: Gandhi (2008); Geddes (1999, 2003); Svolik (2012).

${ }^{3}$ For a more thorough exploration of electoral manipulation in dictatorships than space allows, see Schedler's
} 
Non-democratic leaders intensify uncertainty about the size of their supporting coalitions by exaggerating their support and exacerbating opposition coordination problems (Edmond, 2013; Lohmann, 1993; Kuran, 1989). These efforts suppress movements to remove non-democratic leaders from office because regime opponents cannot accurately juxtapose the strength of the opposition movement against that of the leader's supporting coalition. Lohmann's 1994 study of East Germany describes a country that could have democratized much earlier had the opposition understood its relative strength. Of the uncertainty before the eventual collapse of the German Democratic Republic, she writes:

"While elections were held regularly, there was no opposition party, and election outcomes were manipulated. Periodic intraparty purges effectively eliminated any opposition within the ruling party. The freedom of press, radio, and television guaranteed in Article 27 of the GDR constitution was a farce... public opinion polls that indicated a dramatic decrease in public support for the regime in the late 1970s and throughout the 1980s were classified and not accessible to anyone but high-level functionaries" (pg. 44).

The uncertainty around leader coalitions is worsened by strong incentives to misrepresent allegiances in non-democratic systems. In democracies, leaders provide their large electorates with public goods that are largely non-excludable, meaning the goods one receives from the government are minimally influenced by one's political affiliations (Boix, 2003; Brown and Mobarak, 2009; Deacon, 2009; Bueno de Mesquita et al., 2003; Lake and Baum, 2001; Olson, 1993). ${ }^{4}$ The same cannot be said of non-democratic states. Where opposition leaders and their followers are repressed, there are strong incentives to publicly voice support for an incumbent whom one may not support privately-known political opponents can face lower levels of goods provision or even state-sponsored violence (Bueno de Mesquita et al., 2003; Kuran, 1989, 1991). ${ }^{5}$ For these two reasons-(1) the absence of mechanisms that force public declarations of support for competing candidates for executive office and (2) the strong incentives to feign

The Politics of Uncertainty (2013), Competitive Authoritarianism by Levitsky and Way (2010), and Political Institutions under Dictatorship by Gandhi (2008).

${ }^{4}$ Goods distribution is not perfectly equal in democracies (Bell, 2011; Keefer, 2007; Min, 2015; Ross, 2006), though disparities are smaller than what is observed in non-democracies.

${ }^{5}$ Bueno de Mesquita et al. (2003) call this the "loyalty norm" that helps to preserve non-democratic winning coalitions. 
support for the incumbent-political allegiances in non-democracies are private and prone to miscalculation. This increases the value of events that reveal a leader's true level of support.

\section{Leader Transitions as Information-Revealing Events}

The problem described above resembles a classic signaling game. Non-democratic leaders hold private information about the strength of the coalitions keeping them in power. They also have incentives to exaggerate their strength to any potential rivals, all of whom possess less information about the leader's true strength. The likely outcome of this signaling problem is what formal theorists call a pooling strategy; all dictators do what they can to convey strength. Whether strong or weak, these leaders have incentives to hold sham elections, make examples of political rivals, glorify their successes, control state media, hold militaristic celebrations and parades, and create new holidays and national myths. Any potential challengers must attempt to discern credible signals of strength from empty bluffs, but guessing incorrectly can have devastating consequences. So how can the opposition determine which leaders are truly strong and which ones are feigning support? ${ }^{6}$

The central argument of this paper is that some, though not all, forms of leader entry provide a credible snapshot of the support a new leader enjoys when she takes power. Forms of entry that unequivocally advertise a strong supporting coalition provide the most unambiguous signal of strength. Leaders achieve this by forcibly seizing power and replacing the preceding political system. When a new leader takes power at the head of a rebel army or popular protest movement, the strength and loyalty of her coalition is evinced by their victory over the previous government. Potential opponents can have no doubt that the new leader has the support of a loyal and risk-acceptant bloc of supporters. Major coups that overturn the entire ruling regime (rather than less consequential reshuffling coups) also demonstrate that the new leader's coalition is strong and loyal enough to resist threats to the new government. When popular protests overwhelm a government and place a chosen leader in power, observers can infer that public opposition to subsequent regime change would be great enough to discourage efforts to remove

\footnotetext{
${ }^{6}$ See, among others, the foundational "beer-quiche" game in which both beer-drinkers and quiche-eaters opt for beer so as to signal their toughness to a nearby bully (Cho and Kreps, 1987).
} 
the new incumbent by force. In this way, coming to power through irregular regime replacement can be a boon to new leaders hoping to avoid counter-coups and reactionary uprisings.

\begin{tabular}{|c|c|c|}
\hline ENTRY TYPE & DEFINITION & UNCERTAINTY ABOUT LEADER STRENGTH \\
\hline $\begin{array}{l}\text { Regular } \\
\text { Entry }\end{array}$ & $\begin{array}{l}\text { Entry consistent with constitutional or } \\
\text { established rules for leader selection, } \\
\text { such as normal succession, selection by } \\
\text { party/junta elites, or popular election. }\end{array}$ & $\begin{array}{l}\text { Moderate. New leader has no chance } \\
\text { to display her strength when she } \\
\text { inherits the status quo regime. Entry } \\
\text { does not reveal whether she is strongly } \\
\text { supported or passively accepted by } \\
\text { those beyond the ruling inner circle. }\end{array}$ \\
\hline $\begin{array}{l}\text { Irregular } \\
\text { Reorganization }\end{array}$ & $\begin{array}{l}\text { Entry either violates rules/norms or } \\
\text { occurs where there are no established } \\
\text { rules/norms AND leader rose without } \\
\text { forcefully ousting the old regime, as in } \\
\text { reshuffles or unestablished election, } \\
\text { succession, or selection processes. }\end{array}$ & $\begin{array}{l}\text { High. A reshuffle between insiders in } \\
\text { the governing clique may reveal a new } \\
\text { leader's popularity among the ruling } \\
\text { elite, but it can also advertise the } \\
\text { weakness of the regime to political } \\
\text { rivals outside the ruling clique. }\end{array}$ \\
\hline $\begin{array}{l}\text { Irregular } \\
\text { Replacement }\end{array}$ & $\begin{array}{l}\text { Entry violates established rules or } \\
\text { norms for leader change AND change } \\
\text { results from the coordinated use of } \\
\text { force, as in rebellions, major regime } \\
\text { changing coups, and protest movements. }\end{array}$ & $\begin{array}{l}\text { Low. The new leader took power } \\
\text { with a sufficiently strong and loyal } \\
\text { coalition of supporters. The new leader's } \\
\text { strength is made credible by her success } \\
\text { in forcing the previous leader from office } \\
\text { against the will of the ruling elite. }\end{array}$ \\
\hline
\end{tabular}

When leaders enter power in other ways they cannot convey strength so persuasively. For example, leaders who take power during intra-junta/party reshuffles demonstrate that they have the support of a critical share of the divided ruling elites, but these entries do nothing to deter outsiders who hope to overturn the entire political system. Rather, these regime reorganizations only show that the new leader is the strongest member of an increasingly fractured government. Even when these leadership disputes turn violent, as in many "palace coups" or "reshuffling coups," new leaders only prove that they can force the allegiances of regime insiders. These irregular regime reorganizations allow leaders to arise from internal discord and do not credibly demonstrate that the new coalition is strong enough to take control of the state and thwart threats from regime outsiders.

Regular entries that follow a regime's established norms for leader transition are a hall- 
mark of stable dictatorships, but these transitions reveal relatively little about the size and loyalty of a new leader's coalition. Loyalties do not automatically transfer from a monarch to an heir or from a president to a vice president, and this is why new leaders are so frequently challenged shortly after succeeding their predecessors. Historical studies of Europe's hereditary monarchies suggest succession mechanisms provide stability by dissuading intra-regime infighting, (Kokkonen and Sundell, 2014; Kurrild-Klitgaard, 2000), but family monarchies are increasingly rare (Brownlee, 2007) and these norms may not dissuade regime outsiders. Isabel Perón of Argentina was the clear chosen successor of Juan Perón—she was his wife and vice president-yet she suffered multiple coup attempts and was deposed less than two years after taking power. Kim Jong Un continues to serve as the North Korean President, but his succession was followed by numerous purges, executions, and other demonstrations of strength. International observers continue to question the strength of his coalition, warning that a potential rival could emerge. He did not force his way into office in a complete regime replacement, so we can only speculate about his true level of support within the North Korean military elite.

\section{Which Threats Are Deterred By Credible Signals of Strength?}

The unambiguous signal of strength that occurs when a new leader forcibly replaces her predecessor should deter challengers, though some forms of leader removal should be more sensitive to leader coalition strength than others. Specifically, strong coalitions should deter coalition competition that pits a leader's supporters against an opposition coalition in a direct contest for state control. These forms of removal include civil wars where rebel groups directly engage with forces defending the incumbent's government, coup attempts that seek to overthrow (rather than reshuffle) the government, and popular movements where opposition groups confront the incumbent's supporters in the streets. Coalition-competing threats should be deterred by reliable information about leader coalition strength because the viability of these challenges crucially depends upon opponents' beliefs about the relative strength of the leader's coalition. ${ }^{7}$

\footnotetext{
${ }^{7}$ Little 2015 and Casper and Tyson 2014 similarly argue political rivals can make inferences about nondemocratic leader strength following elections and protests, respectively, though perceptions of both events may be prone to government manipulation and state-controlled media.
} 
Table 2: How Involuntary Leader Exits Are Affected By Signals of Leader Strength

Removal TyPe Definition SENSITIVITy to Leader Strength

Coalition Unconstitutional removal in which

Competing a coalition of regime outsiders overthrows the ruling government in a direct competition for power.

Coalition

Circumventing

Coalition

Collapsing
Unconstitutional removal where regime outsiders evade direct competition with the incumbent's coalition by using assassins or turning to foreign superpowers.

The leader is forced from power involuntarily during reshuffling among members of the regime, usually in "palace coups d'état" or pseudo-legal impeachments.
High. The viability of the attempt depends upon the relative strength of the incumbent's supporters vis-á-vis the opposition coalition.

Low. The viability of the challenge is minimally influenced by leader strength because challengers avoid direct coalition competition or use substantially stronger foreign allies.

Low. The viability of the challenge is minimally influenced by leader strength because challengers emerge from within the regime and convince others to reallocate political power.

Other threats to leaders eschew direct competition between the coalitions of the leader and an opposition movement and, therefore, should not be similarly deterred by demonstrations of leader coalition strength. We call these forms of removal coalition circumvention. Assassins, for example, remove a leader from power with no intention of overcoming the leader's supporters and placing an opposition member in power. When the ruler of the Democratic Republic of the Congo, Laurent Kabila, was assassinated by a child soldier in 1999, the young assassin surely was not attempting to place himself or another regime outsider in office. This threat to Kabila occurred despite the strength of his supporting coalition. Kabila's formidable coalition-his son is now approaching two decades in power-could have been a primary motivation for using a removal tactic that would intentionally circumvent coalition competition. Opponents also circumvent competition with they enlist global or regional superpowers to remove the incumbent from office. Non-democratic leaders suffer foreign overthrows relatively infrequently (we count only 24 since 1950), but when they do they are typically overthrown by states that are far too strong to be meaningfully deterred by the way in which a leader came 
to power. American actions against Mohammad Mossadeg (Iran, 1953) and Mullah Omar (Afghanistan, 2001) typify the overwhelming strength of the foreign country during these transitions, as do French actions against Bokassa (C.A.R., 1979) and Soviet moves against Nagy (Hungary, 1956), Karmal (Afghanistan, 1986), and Tsedenbal (Mongolia, 1984).

Having had a strong coalition at the time of entry does little to protect leaders from threats emerging from within the coalition. These kinds of threats do not force challengers to overcome the coalition that put the leader in power. Rather, they constitute reshuffles among coalition members that demote the incumbent leader. We call these internal realignments and reshuffles coalition collapse. This form of removal includes two ways that leaders are involuntarily replaced by members of their own governments: reshuffling coups and legal processes like impeachment. Because these forms of removal do not require challengers to overcome the leader's united coalition, these threats should be minimally affected by any signals sent by a leader's method of entry into office.

It follows from this argument that the irregular regime replacements that send the most unambiguous signals of leader coalition strength should dissuade the coalition competing threats that are most sensitive to the strength of an incumbent's supporting coalition. Forms of removal that are minimally affected by coalition strength vis-à-vis outsiders should not be similarly deterred by irregular regime replacement. Accordingly:

H1: Non-democratic leaders coming to power via irregular regime replacement are less likely to suffer removal by coalition competition.

$H 2$ : Non-democratic leaders coming to power via irregular regime replacement are no less likely to suffer removal by coalition circumvention or collapse.

\section{Signals of Strength Will Fade Over Time}

The argument requires a final caveat. The importance of any signal fades with time, both because the information conveyed by the signal is less recent and, in this context, because political realities often force dictators to reconstitute their supporting coalitions. Work on the institutionalization of non-democratic governments highlights both of these time-sensitive mechanisms. When necessary, dictators rebuild their coalitions using strategies like purging, ideological re- 
alignment, and political party formation (Sudduth, 2017; Gandhi, 2008; Magaloni, 2008; Svolik, 2012). Sudanese President Omar al-Bashir, for example, famously rose to power in a coup supported by fundamentalist Islamists like the theocrat Hassan al-Turabi. Islamism was prominent in the early years of his regime, but al-Bashir severed his ties to this movement once he consolidated power and gained the ability to personalize his regime. Over the course of alBashir's 25 years in office his government has gone from courting al Qaeda and aggressively pursuing Islamization to jailing Hassan al-Turabi and calling the Muslim Brotherhood a terrorist organization. This is a clear example of how the way a leader entered power becomes less relevant as political conditions change with time.

Even where leaders are somewhat less intentional about reshaping their supporting coalitions, we would argue that the passage of time depreciates the value of the information provided by a leader's entry and therefore weakens any deterrent effect that an irregular regime replacement might have on subsequent political challenges. Fidel Castro's successful revolution in Cuba provided opponents with a much better understanding of Fidel's military strength in the early 1960s than it did in the early 2000s. Thus, we posit an additional conditional hypothesis:

H3: The magnitude of any relationship between leader entry type and leader exit type will fade with a leader's time in office.

\section{Data}

Our dataset of non-democratic leader transitions consists of leader-year panels for the 773 individuals who took control of a non-democratic government between 1950 and 2016 and then held power for at least one week. ${ }^{8}$ To generate this leader list, we first used the data and coding rules produced by Cheibub, Gandhi and Vreeland (2010) to identify periods of non-democratic rule in every sovereign state. Cheibub, Gandhi and Vreeland (2010) use a

\footnotetext{
${ }^{8}$ The "one-week rule" is standard practice in this research literature because many contested leader transitions see power change hands several times over the course of the conflict. Without an arbitrary threshold for timein-power, many failed coups would produce temporary "leaders" who served for a few hours and never emerged from the initial conflict for power with any real capacity to govern. See, for example, the failed coup in Sudan that occurred 19-23 July 1971.
} 
procedural definition of democracy that labels governments non-democratic if executive offices are not filled through legitimate and contested elections. According to this definition, 141 countries were non-democratic at some point between 1950 and 2016.

Next, we consulted several datasets and codebooks (Cheibub, Gandhi and Vreeland, 2010; Goemans, Gleditsch and Chiozza, 2009; Svolik and Akcinaroglu, 2007) to create a list of leaders serving during these non-democratic periods, taking special care to correctly assign leaders to regimes during years that experienced major regime change. These sources occasionally disagree about the identity of a country's chief leader because some favor nominal headsof-government while others list the de facto or "effective" leader. We resolved these differences by doing case research to identify de facto leaders. Finally, we excluded the short-lived tenures of "leaders" who merely served as placeholders (i.e. Kebreau in Haiti). We recoded 93 (out of 773) leaders in our dataset as placeholders and excluded them from our analyses. Our main findings do not substantially change when they are included, though including them increases the estimated probability of a voluntary resignation and decreases estimated likelihoods of all irregular forms of leader removal. We provide a complete list of our leaders, placeholders, and transition types in a supplementary appendix. ${ }^{9}$

\section{Leader Entry Types}

We assign each leader one of eight entry types. Most non-democratic leader transitions are regular and voluntary, meaning that they are not forced by a major crisis and they occur with the consent of the outgoing regime. If such transitions occur as part of a precedented process for leader selection, as in regular elections, succession structures, and normal selection by the party/junta, then we label these Regular Selection/Election. Leaders entering this way include most heirs in monarchies, rising party members, and winners of precedented elections. If the entry was unprecedented but otherwise peaceful and voluntary, as in first-time transi-

\footnotetext{
${ }^{9}$ Using two independent coders, we were able to achieve an inter-coder reliability of $97 \%$ after the first attempt to construct the data. Additional sources were consulted to classify the more ambiguous cases, many of which involved uncertainty about the role of foreign actors or whether assassinations were part of larger coup or rebel conspiracies. We identified placeholders using the LEAD data and coding rules from Ellis, Horowitz and Stam (2015). All decisions and a leader-by-leader comparison to Archigos (4.1) are included in a supplementary appendix.
} 
tions between regime founders and their heirs (e.g. Fidel to Raul Castro in Cuba) or initial appointments at state independence (e.g. Sékou Touré in Guinea), we code the entry as First Selection/Election. We make this distinction so we can determine whether regular forms of leader entry better insulate leaders from challenges if those regular entries are legitimized by historical precedent. These two types of leader entry describe about half of the 773 leaders in the dataset, with 259 entering by Regular Election/Selection (33.5\%) and 172 (22.3\%) rising through First Election/Selection.

Nearly half of all non-democratic leaders entered in more tumultuous "irregular" transitions, but we differentiate between six different forms of irregular entry. When governments are compelled to choose a new leader during a major crisis, such as a popular protest or assassination, we call this Forced Election/Selection. These entries are different from other irregular entries in that the outgoing government chooses the new leader during the crisis. These entries are not common (88 of 773, or 11.4\%), but high-profile examples include Egypt's Hosni Mubarak following the killing of Anwar Sadat and Nigeria's Olusegun Obasanjo, who first entered office when a botched coup attempt failed to oust the ruling regime but succeeded in killing the leader of the junta in which Obasanjo served. These entries can also occur during war if a war forces the old leader out, yet does not put a rebel leader in power. The rebellion against Charles Taylor in Liberia's second civil war (1999-2003) removed Taylor, but when he vacated office his position transferred to a regime insider, Vice President Moses Blah, rather than someone affiliated with the rebel movement. This ascent, despite being triggered by war, is a Forced Election/Selection.

All other forms of entry occur without the consent of the government. Foreign Installation (20 leaders, 2.6\%) occurs when new leaders are put in place by the governments of other countries. These transitions require more than foreign assistance (as in some coups and rebellions). Instead, the foreign government must be the main armed force that selects the new leader. Successful Rebellion (27 leaders, 3.5\%) and Successful Protest (4 leaders, 0.5\%) occur when governments are forced from power and the leaders of the rebel or protest movements claim power for themselves. Finally, we follow Aksoy, Carter and Wright (2015) by making 
a distinction between two types of coups: the Reshuffling Coup that puts a new individual in charge of the extant political regime and the Regime-Changing Coup in which the new leader significantly and immediately changes political institutions and/or the nature of executive power. ${ }^{10}$ Taken together, Reshuffling Coups (95 leaders, 12.3\%) and Regime-Changing Coups (108 leaders, 14.0\%) account for one in four non-democratic leader entries.

Next, we classify these eight types into the broader theoretically-relevant categories discussed above (also see Table 3 below). The only regular methods are Regular Election/Selection and First Election/Selection. In both cases power is transferred voluntarily by the previous government. Irregular regime reorganizations occur when the change is involuntary, yet the ruling regime is minimally changed, as in a Forced Election/Selection or Reshuffling Coup. Irregular regime replacements occur during a Regime-Changing Coup, Successful Protest, or Successful Rebellion. Foreign Installation is a distinct category.

\section{Leader Exit Types}

Because we theorize that strong leader coalitions dissuade some strategies for leader removal but not others, we also classify leader exits into several types. Voluntary Resignation occurs when leader exit is completely voluntary (378 leaders, $48.9 \%$ ) or forced only by failing health (8 leaders, 1.0\%). An additional 53 leaders (6.9\%) exited through Natural Death. Rumors surround leader deaths and resignations in dictatorships, but we code these events as healthinduced unless there is very strong evidence that false health reports were used as a pretext for a more nefarious plot to force the leader from power.

We code two kinds of involuntary removal from within the regime (coalition collapse). A Reshuffling Coup occurs when a leader is forcibly removed by a secret internal faction that splits her coalition. These coups do not overthrow the entire government, but instead change the leadership structure among the ruling elite. 83 of the non-democratic leaders who entered power after $1950(10.7 \%)$ lost power this way. Leaders can also be forced out under legal pretenses. These instances of Legal Removal are involuntary and undermine the internal cohesion

\footnotetext{
${ }^{10}$ We expand their dataset to include more coups and a longer time period. We also recoded some coups. All of these decisions are included in the online appendix.
} 
of the regime, but they use available legal structures for removal rather than subversive coup conspiracies. We count only 19 cases (2.5\%), including Razak's faction of Malaysia's UMNO party successfully overcoming Tunku Abdul Rahman, the country's first prime minister. These forms of coalition collapse similarly pit one faction of the ruling coalition against the other, though the former is usually a secret conspiracy while the latter is often a prolonged and public legal battle.

We divide threats emerging from outside the ruling coalition into two broad categories: coalition competition and coalition circumvention (refer to Table 2). Coalition-competing methods of leader removal are most likely to be deterred by a strong leader because they require a challenger to forcibly remove the governing coalition. The three types of coalition-competing removal are: Regime-Changing Coup (66 leaders, 8.5\%), Protest (31 leaders, 4.0\%), and $\boldsymbol{R e}$ bellion (28 leaders, 3.6\%). Note that the number of leaders to leave power in these ways will not perfectly align with the number of leaders to enter in these ways. For example, 31 leaders were forced out by protests but only 4 leaders entered through protest. A primary cause for this is democratization; those who enter after successful protests often democratize and this is a dataset of non-democratic leaders.

Our last two forms of leader removal are Assassination (19 leaders, 2.5\%) and Foreign Overthrow (24 leaders, 3.1\%). We consider both of these exit types to be different from the coalition-competing challenges listed above because neither is particularly deterred by leader strength. Assassination attempts that are not linked to larger conspiracies and are not deterred by a leader's coalition strength because "lone-wolf" assassins have no intention of combating a leader's coalition of supporters. Foreign governments with the capacity to overthrow other states' incumbents are much stronger than their targets.

\section{Control Variables}

We anticipate any consequences of leader entry type to be tempered by the amount of time a leader has held power, so the models also include Leader Tenure measured in logged years and some models also include multiplicative interactions of tenure with specific entry types. 


\begin{tabular}{|c|c|c|c|c|}
\hline \multicolumn{5}{|c|}{ Table 3: A Typology of Leader Entry and Exit } \\
\hline \multicolumn{5}{|c|}{ LEADER ENTRY } \\
\hline REGULAR & $\begin{array}{l}\text { IRREGULAR } \\
\text { REPI }\end{array}$ & $\begin{array}{c}\text { IRREGULAR } \\
\text { REORGANIZATION }\end{array}$ & FOREIGN & \\
\hline $\begin{array}{l}\text { Regular Selection } \\
\text { First Selection }\end{array}$ & $\begin{array}{c}\text { Rebellion } \\
\text { Protest } \\
\text { Regime Coup }\end{array}$ & $\begin{array}{l}\text { Reshuffle Coup } \\
\text { Forced Selection }\end{array}$ & Installation & \\
\hline & & LEADER EXIT & & \\
\hline $\begin{array}{l}\text { VOLUNTARY } \\
\text { RESIGNATION }\end{array}$ & $\begin{array}{l}\text { NATURAL } \\
\text { DEATH }\end{array}$ & $\begin{array}{c}\text { COALITION } \\
\text { COMPETITION }\end{array}$ & $\begin{array}{c}\text { COALITION } \\
\text { CIRCUMVENTION }\end{array}$ & $\begin{array}{l}\text { COALITION } \\
\text { COLLAPSE }\end{array}$ \\
\hline $\begin{array}{l}\text { Election/Selection } \\
\text { Health Reasons }\end{array}$ & Death & $\begin{array}{l}\text { Rebellion } \\
\text { Regime Coup } \\
\text { Protest }\end{array}$ & $\begin{array}{l}\text { Foreign Action } \\
\text { Assassination }\end{array}$ & $\begin{array}{l}\text { Reshuffle Coup } \\
\text { Legal Removal }\end{array}$ \\
\hline
\end{tabular}

Age is included so we can better separate the effects of tenure longevity from other time trends like waning health and perceptions of leader frailty. We include Logged pcGDP to capture a state's level of economic development, anticipating that states with a lower per capita gross domestic product will be more prone to irregular forms of leader change. Economic Growth is measured as the annual change in per capita gross domestic product and we expect higher rates of economic growth to decrease the risk of irregular forms of leader change. Both economic variables are drawn from The Maddison Project (Bolt and van Zanden, 2014). Different nondemocratic political systems are likely to suffer different kinds of challenges. Using the data by Cheibub, Gandhi and Vreeland (2010), we account for whether the regime is a monarchic, military, or civilian dictatorship. Monarch and Military Dictator are dichotomous variables indicating whether the regime's decision-making relies on family and kin networks, or the armed forces within juntas. The base category in our analyses is a civilian dictatorship. In addition, we control for Party which is a dichotomous variable indicating whether there is any de facto party ruling the regime.

Conflict involvement is also linked to leader survival (Bueno de Mesquita et al., 2003; Goemans, 2008; Chiozza and Goemans, 2011; Debs and Goemans, 2010), so we use several 
control variables to indicate the presence of conflict, a leader's role in the conflict, and recent performance in conflict. We include a dichotomous Civil War variable that is equal to 1 when states are presently involved in a civil war, drawn from the UCDP/PRIO Armed Conflict Dataset v.4-2012 (Gleditsch et al., 2002; Themnér and Wallensteen, 2012). We expect that ongoing war increases the risk of an irregular leader replacement. We also include Logged Military Personnel to capture an additional aspect of state militarization (Singer, 1987). Leaders are rewarded for success in international conflicts and may be punished for defeat (Debs and Goemans, 2010), so we also include three measures of recent Victory, Defeat, and Draw in prior conflicts. Following this work, we expect these effects to depreciate with time and capture this with a decay function. ${ }^{11}$ The original source of this data on qualifying crises and results is the International Crisis Behavior dataset (Brecher and Wilkenfeld, 2000).

\section{Analysis}

Leaders confront simultaneous threats of many different forms of removal, and consequently the risk of one type must be evaluated relative to the risk of any others. Statistical models that predict the risk of only one form of leader exit are insufficient because they cannot provide adequate information about these competing threats. For example, a model that estimates the risk of removal by coalition competition could not differentiate between one leader who faces a low risk because she is very likely to stay in power and another leader who faces a low risk because she is much more likely to voluntarily resign, die in office, or be overthrown by a foreign power. Understanding leader exit requires an estimation strategy that is more sensitive to the simultaneous threats leaders suffer.

We overcome this problem by using multinomial logit models that predict the relative likelihoods of six possible outcomes each year a leader is in power: (1) staying in power, (2) removal by coalition competition, (3) removal by coalition circumvention, (4) removal by coalition collapse, (5) voluntary resignation, or (6) natural death. ${ }^{12}$ This method produces a

\footnotetext{
${ }^{11}$ These variables are equal to $\frac{1}{t-t_{R}+1}$ where $t_{R}$ is the year of the outcome and $t$ is the year observed.

${ }^{12} \mathrm{As}$ a robustness check, we ran multinomial logit models by coding the natural death as censored cases. The
} 
unique prediction for each of the six possible outcomes for each year of a leader's tenure and these predictions always sum to 1 (or 100\%). We use "staying in power" as the base category and present the results for each of the five exit types.

In Table 4 we interact each entry category with the $\log$ (Tenure) variable to see how each form of entry influences the risk of each form of exit during a leader's time in power. We use Irregular Replacement Entry as our base category so that all estimates are relative to leaders who entered power in this way. A positive coefficient on another entry type means those leaders are more likely than a leader who entered through irregular regime replacement to experience that kind of leader exit in their first year in power. Our hypotheses would therefore expect strong positive relationships between the other entry types and coalition-competing removal with negative interactions between the other entry types and time in power (H1 and H3). Meanwhile, we would expect there is no statistically significant relationships between each entry type and coalition-circumventing or coalition-collapsing removal (H2). As many implications of interaction terms can be difficult to diagnose from these coefficients alone, we graphically illustrate the effect of leader entry type on each exit type calculated as the first difference in Figures 1 and 2.

The first column of results in Table 4 shows how leader entry influences the risk of a coalition-competing exit (removal by rebellion, protest, or regime-changing coup). The positive and significant coefficients for Regular Entry and Irregular Reorganization Entry show that, as predicted, leaders coming to power in these ways are significantly more likely than leaders who entered in regime replacements to suffer these kinds of challenges early in their tenures. Furthermore, in accordance with the third hypothesis, the negative coefficients on the interaction terms between these entry categories and leader tenure indicate this effect diminishes over a leader's time in power.

To visualize this, we plot the effect of irregular regime replacement entry on the risk of a coalition-competing exit across leader tenure in Figure 1. The effect of irregular regime replacement entry is calculated as the first difference, a change in the risk of a coalitionresults are reported in the online appendix and are consistent with the results shown in the main text. 
Table 4: Multinomial Logit Analysis of Manner of Losing Office in Dictatorships

\begin{tabular}{|c|c|c|c|c|c|}
\hline \multirow{3}{*}{$\begin{array}{l}\text { Dependent Variable } \\
\text { Exit Manner }\end{array}$} & \multicolumn{5}{|c|}{ Model 1} \\
\hline & Coalition & Coalition & Coalition & Voluntary & Natural \\
\hline & Competing & Circumventing & Collapsing & Resignation & Death \\
\hline \multicolumn{6}{|l|}{ Base Category } \\
\hline Entry Manner & \multicolumn{5}{|c|}{ Irregular Replacement Entry } \\
\hline \multicolumn{6}{|l|}{ Independent Variables } \\
\hline \multirow[t]{2}{*}{ Regular Entry } & $1.885 * * *$ & -1.823 & .306 & -.198 & -1.055 \\
\hline & $(.660)$ & (1.247) & $(.446)$ & $(.505)$ & (1.223) \\
\hline \multirow[t]{2}{*}{ Regular $\times \log ($ Tenure $)$} & $-.510 *$ & .868 & -.358 & $.379 *$ & .360 \\
\hline & $(.273)$ & $(.627)$ & $(.265)$ & $(.224)$ & $(.435)$ \\
\hline \multirow[t]{2}{*}{ Irregular Reorganization Entry } & $2.575^{* * *}$ & .425 & .352 & .483 & -.743 \\
\hline & $(.535)$ & ( 1.021$)$ & $(.533)$ & $(.466)$ & $(.954)$ \\
\hline \multirow[t]{2}{*}{ Reorganization $\times \log ($ Tenure $)$} & $-.776 * * *$ & .209 & .424 & .108 & .334 \\
\hline & $(.287)$ & $(.720)$ & $(.311)$ & $(.267)$ & $(.429)$ \\
\hline \multirow[t]{2}{*}{ Foreign Entry } & .741 & -.045 & $-14.380^{* * *}$ & -2.638 & $-13.132 * * *$ \\
\hline & $(1.806)$ & $(.955)$ & $(.745)$ & $(2.301)$ & $(1.498)$ \\
\hline \multirow[t]{2}{*}{ Foreign $\times \log ($ Tenure $)$} & .349 & .840 & $.771 *$ & $1.104 *$ & -.399 \\
\hline & $(.851)$ & $(.672)$ & $(.422)$ & $(.664)$ & $(.485)$ \\
\hline \multirow[t]{2}{*}{$\log ($ Tenure $)$} & $.632 * * *$ & -.591 & $-.507 * *$ & $-.453 * *$ & .090 \\
\hline & $(.204)$ & $(.441)$ & $(.222)$ & $(.213)$ & $(.347)$ \\
\hline \multicolumn{6}{|l|}{ Controls } \\
\hline \multirow{2}{*}{$\ln (\mathrm{GDP} /$ capita $)$} & $-.354 * * *$ & .025 & -.209 & .116 & -.329 \\
\hline & $(.136)$ & $(.150)$ & $(.129)$ & $(.138)$ & $(.217)$ \\
\hline \multirow[t]{2}{*}{ GDP Growth } & $-3.235 * * *$ & -1.80 & -.172 & -.544 & -.030 \\
\hline & $(.867)$ & ( 1.686$)$ & $(.600)$ & $(.777)$ & (.224) \\
\hline \multirow[t]{2}{*}{ Military Dictatorship } & -.082 & .252 & $.714 * *$ & $.657 * * *$ & .056 \\
\hline & $(.300)$ & $(.501)$ & $(.340)$ & $(.251)$ & $(.527)$ \\
\hline \multirow[t]{2}{*}{ Monarchy } & $-2.082 * * *$ & -.497 & -.373 & -.777 & $1.476^{* *}$ \\
\hline & $(.796)$ & $(.583)$ & (.591) & (.608) & $(.618)$ \\
\hline \multirow[t]{2}{*}{ Party } & $-2.057 * * *$ & -.428 & $-.739 * *$ & $1.058 * *$ & -.284 \\
\hline & $(.399)$ & $(.547)$ & $(.339)$ & $(.429)$ & $(.672)$ \\
\hline \multirow[t]{2}{*}{ Ln(Military Personnel) } & $-.166^{*}$ & .078 & -.074 & .048 & .135 \\
\hline & (.096) & $(.151)$ & $(.075)$ & $(.061)$ & $(.118)$ \\
\hline \multirow[t]{2}{*}{ Civil War } & $1.861 * * *$ & $.899 *$ & .392 & .250 & -.647 \\
\hline & $(.274)$ & $(.473)$ & $(.347)$ & $(.232)$ & $(.562)$ \\
\hline \multirow[t]{2}{*}{ War Victory } & $-2.383^{*}$ & $-7.184 * *$ & -5.272 & -2.305 & $1.180 * *$ \\
\hline & ( 1.243$)$ & $(2.946)$ & (3.693) & ( 1.462$)$ & $(.583)$ \\
\hline \multirow[t]{2}{*}{ War Defeat } & $.962 *$ & $3.095 * * *$ & .533 & -.010 & .710 \\
\hline & $(.513)$ & $(.587)$ & $(.725)$ & (.689) & $(.565)$ \\
\hline \multirow[t]{2}{*}{ War Draw } & -.569 & -1.251 & -.813 & -.846 & .484 \\
\hline & $(.489)$ & (1.032) & $(.627)$ & $(.658)$ & $(.656)$ \\
\hline Age & $.041^{* * *}$ & $.048^{* *}$ & $.025^{* *}$ & $.045^{* * *}$ & $.061 * * *$ \\
\hline & $(.013)$ & (.021) & $(.011)$ & $(.010)$ & $(.012)$ \\
\hline Constant & $-3.682 * * *$ & $-7.130 * * *$ & $-2.565 * * *$ & $-7.388 * * *$ & $-6.529 * * *$ \\
\hline & $(.943)$ & $(1.332)$ & $(.901)$ & $(.942)$ & $(1.532)$ \\
\hline Log Likelihood & & & -1459.863 & & \\
\hline Observations & & & 3613 & & \\
\hline
\end{tabular}

Note: Robust country-clustered standard errors are in parentheses. $* p<0.10$; ** $p<0.05$; *** $p<0.01$. We provide the first differences predicted from this model in Figures 1 and 2.

competing exit a leader would suffer when her entry type is switched from either regular or irregular reorganization to irregular replacement when all other variables in the model are held constant at their means or medians. We used Model 1 in Table 4 to estimate the first differences. As predicted by our first hypothesis, Figure 1 shows that leaders who enter through irregular regime replacements are less likely to suffer removal by coalition competition than 
Figure 1: Effect of Irregular Replacement Entry on Coalition-Competing Removal
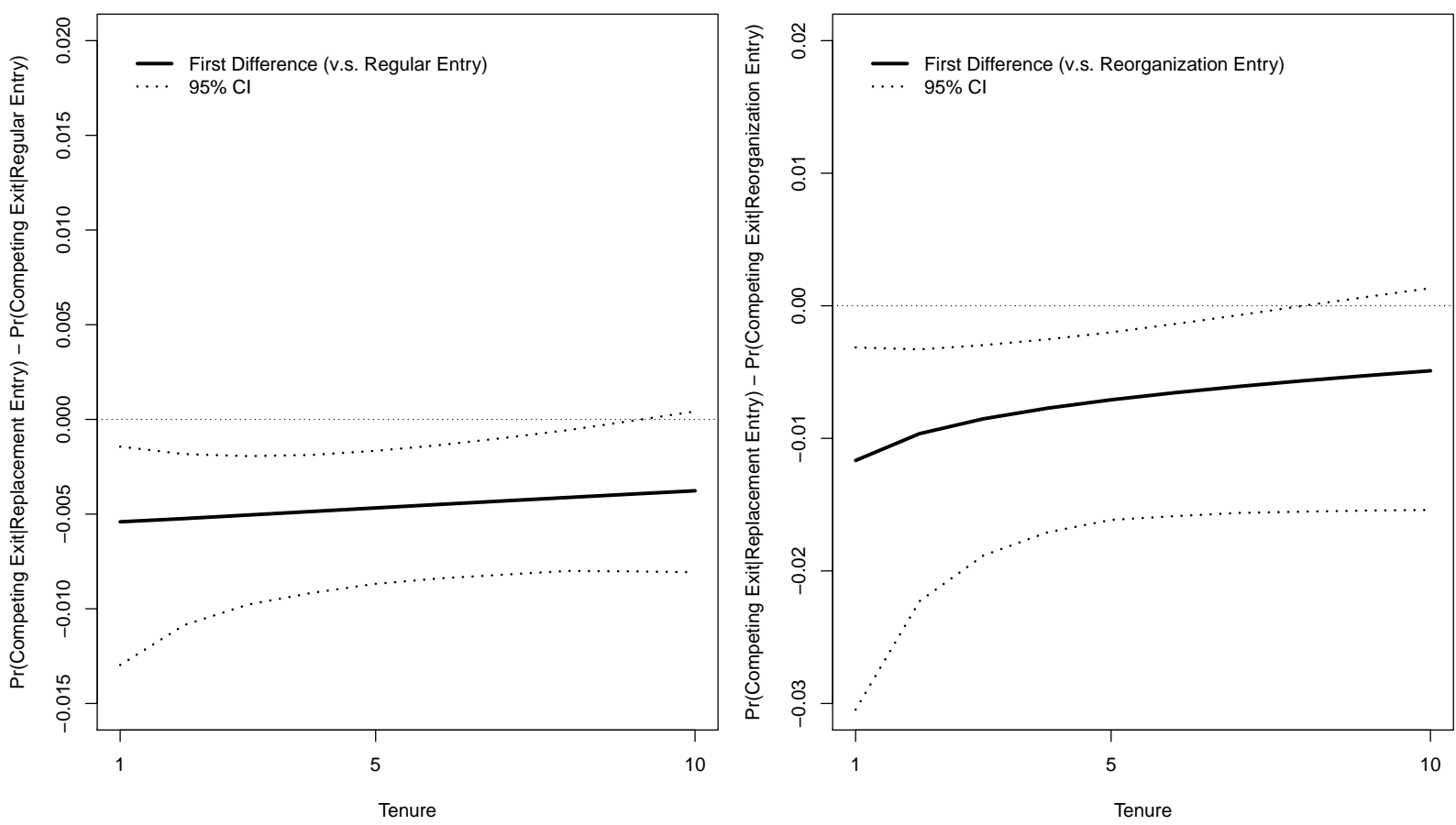

Note: We show the change in predicted probabilities of coalition-competing removal when we change entry manner from either regular (the left panel) or irregular reorganization (the right panel) to irregular replacement. We use Model 1 in Table 4 to estimate the first difference.

either leaders who enter through regular (the left panel) or irregular reorganizations (the right panel) early in their tenure. This advantage, however, gradually wanes and irregular replacement entry stops having a significantly negative effect after approximately 9 (v.s. regular entry) or 8 (v.s. irregular reorganization entry) years in power. This is congruent with our expectation that the way a leader entered office should become less relevant the longer the leader stays in power. Regarding the control variables, the results of the first column in Table 4 corroborate previous research that finds these kinds of threats to be less likely when states enjoy greater economic prosperity, more success in foreign armed conflicts, and either party-based or monarchical political institutions (Debs and Goemans, 2010; Magaloni, 2008; Kokkonen and Sundell, 2014; Londregan and Poole, 1990).

The method of leader entry does not have a similar effect on irregular removal by coalition circumvention (assassinations and overthrows) and coalition collapse (internal reshuffles and legal removals), as evinced by the statistically insignificant effects provided in the sec- 
ond and third columns in Table 4. The first differences reported in Figure 2 also confirm this point. ${ }^{13}$ Leaders coming to power via irregular regime replacement are no less likely to suffer removal by coalition circumvention (the top row) or collapse (the bottom row) than leaders coming to power via regular processes (the left panel) or irregular reorganizations (the right panel). Though the difference of the risk of coalition-collapsing exit between irregular regime replacement and irregular reorganization entry is statistically significant after 3 years in power (see the bottom-right panel), the effect of irregular replacement entry is insignificant at the very beginning of a leader's tenure when the value of the information provided by a leader's entry should be the strongest. These results thus show that the insulating effects of leader entry by complete regime replacement are limited to coalition-competing forms of removal, and this is congruent with our expectations (H2). Assassins, foreign powers, and internal factions are not deterred by leaders who force their way into office with a credible show-of-strength. Instead, leaders who prove strength through irregular regime replacement are only insulated from extracoalition threats that would require rivals to compete with and overcome the leader's strong coalition.

Our initial test collapsed many forms of leader entry into four theoretically-relevant categories: regular entry, irregular regime replacement, irregular regime reorganization, and foreign installation. However, there could be important variation within these broader categories. Table 5 presents two models in which we disaggregate these entry types to examine whether our findings are driven by anomalous results for a more specific means of taking power. Most importantly, we separate irregular replacements into two groups: regime-changing coups and successful protests/rebellions. Model 2 shows the effects of these specific entry types relative to regular forms of entry. Model 3 does the same but uses forms of irregular regime reorganization as the base category for comparison. ${ }^{14}$

\footnotetext{
${ }^{13}$ The first differences in Figure 2 are calculated as the changes in predicted probabilities of coalition circumvention removal or coalition collapse removal when we change entry manner from either regular or irregular reorganization to irregular regime replacement. We use Model 1 in Table 4 for the estimation.

${ }^{14}$ Due to the extremely low number of leaders entering through successful protests, it is not feasible for us to further disaggregate this category.
} 
Figure 2: Effect of Irregular Replacement Entry on Coalition-Circumventing and Collapsing Removal
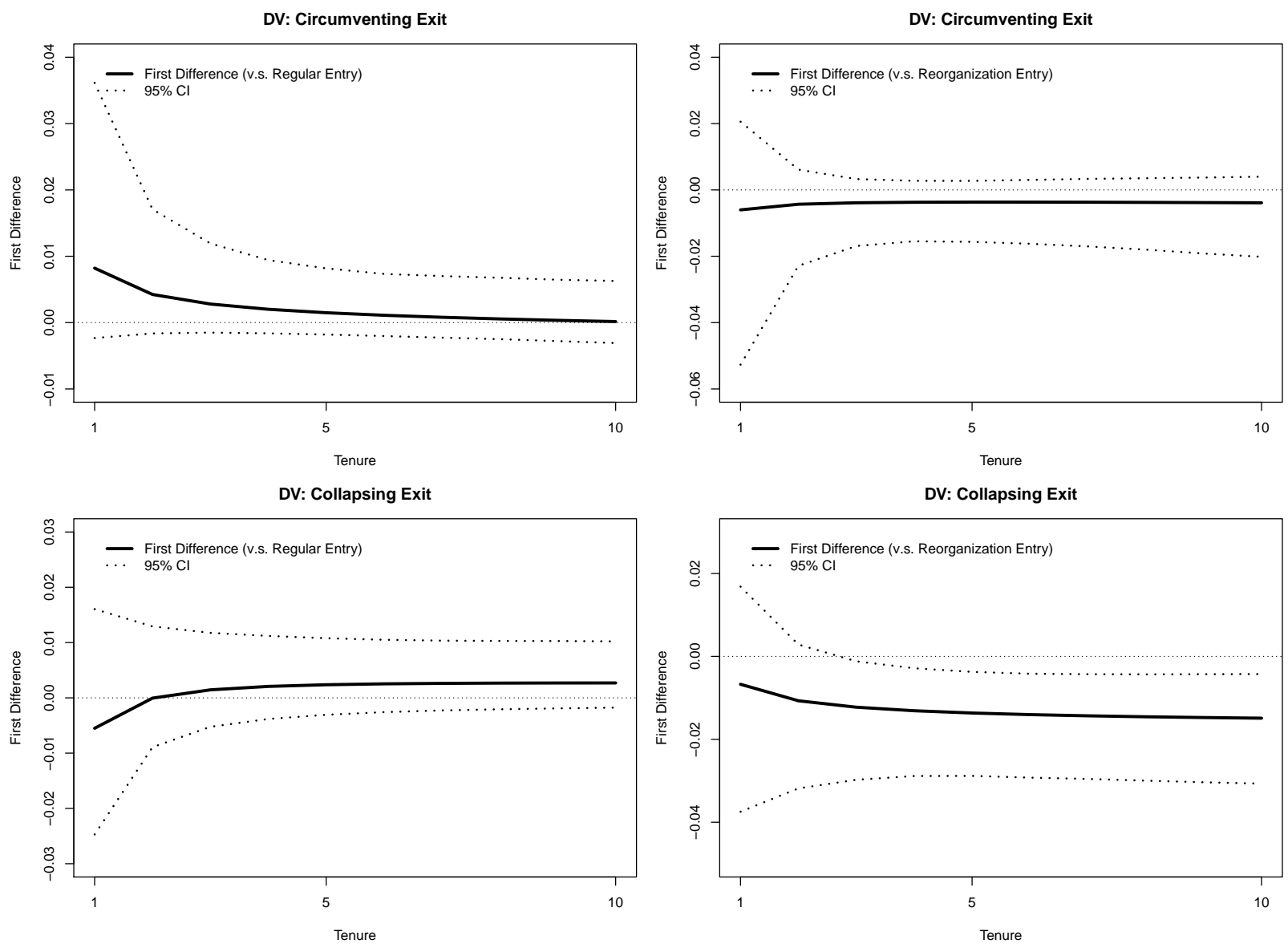

Note: We show the changes in predicted probabilities of coalition circumvention removal (the top panel) and coalition collapse removal (the bottom panel) when we change entry manner from either regular (the left panel) or irregular reorganization (the right panel) to irregular regime replacement. We use Model 1 in Table 4 to estimate the first difference.

The results of these tests provide very strong justification for categorizing these entry types according to the strength they convey to potential challengers. Beginning with the results for coalition-competing removal, we see very similar results for the two disaggregated forms of irregular regime replacement, and importantly, coalition-competing challenges are least likely to occur against leaders who took power in these ways. There is no meaningful difference between leaders entering through successful rebellions or protests and those entering through major regime-changing coups (the respective coefficients are -2.14 and -1.84 in Model 2, -2.80 and -2.52 in Model 3). In Figure 3, we chart the near-identical effects of these two forms of irregular regime replacement on coalition-competing leader removal. 
Table 5: Multinomial Logit Analysis of Manner of Losing Office in Dictatorships

\begin{tabular}{|c|c|c|c|c|c|c|c|c|c|c|}
\hline \multirow{3}{*}{$\begin{array}{l}\text { Dependent Variable } \\
\text { Exit Manner }\end{array}$} & \multicolumn{5}{|c|}{ Model 2} & \multicolumn{5}{|c|}{ Model 3} \\
\hline & Coalition & Coalition & Coalition & Voluntary & Natural & Coalition & Coalition & Coalition & Voluntary & Natural \\
\hline & Competing & Circumventing & Collapsing & Resignation & Death & Competing & Circumventing & Collapsing & Resignation & Death \\
\hline \multicolumn{11}{|l|}{ Base Category } \\
\hline Entry Manner & \multicolumn{5}{|c|}{ Regular Entry } & \multicolumn{5}{|c|}{ Irregular Reorganization Entry } \\
\hline \multicolumn{11}{|l|}{ Irregular Replacement Entry } \\
\hline \multirow{2}{*}{ Rebel Entry } & $-2.135^{* * *}$ & -.319 & $-2.288^{*}$ & $1.837 * *$ & $2.495^{* *}$ & $-2.797 * * *$ & $-2.421 * *$ & $-2.410 * *$ & 1.223 & $2.406^{* *}$ \\
\hline & (.646) & $(1.422)$ & (1.227) & $(.763)$ & (1.037) & $(.576)$ & (1.174) & $(1.210)$ & $(.798)$ & (1.173) \\
\hline \multirow[t]{2}{*}{ Rebel $\times \log ($ Tenure $)$} & .470 & .038 & $1.100 * * *$ & $-1.262 * *$ & -.423 & $.727 *$ & .584 & .312 & $-.988^{*}$ & -.428 \\
\hline & $(.388)$ & $(.634)$ & (.353) & $(.564)$ & (.479) & $(.416)$ & (.673) & $(.347)$ & $(.579)$ & $(.497)$ \\
\hline \multirow[t]{2}{*}{ Regime-Change Coup Entry } & $-1.836^{* *}$ & $2.511^{*}$ & -.193 & -.376 & -.165 & $-2.524 * * *$ & .159 & -.221 & $-1.054 * *$ & -.073 \\
\hline & $(.782)$ & $(1.395)$ & $(.455)$ & $(.577)$ & $(1.683)$ & $(.613)$ & $(1.081)$ & $(.535)$ & $(.517)$ & $(1.515)$ \\
\hline \multirow[t]{2}{*}{ Regime-Change Coup $\times \log ($ Tenure $)$} & $.518^{*}$ & -1.120 & .329 & -.138 & -.429 & $.774 * * *$ & -.446 & -.470 & .122 & -.482 \\
\hline & $(.291)$ & $(.692)$ & $(.273)$ & $(.244)$ & $(.650)$ & $(.296)$ & $(.766)$ & $(.312)$ & $(.284)$ & $(.626)$ \\
\hline Irregular Reorganization Entry & & & & & & & & & & \\
\hline Reshuffling Coup Entry & .131 & 1.844 & .134 & $.816^{* *}$ & -.469 & & & & & \\
\hline & $(.833)$ & $(1.296)$ & $(.557)$ & $(.378)$ & (1.371) & & & & & \\
\hline Reshuffling Coup $\times \log$ (Tenure) & .158 & -.054 & $.632 * *$ & $-.425 *$ & .064 & & & & & \\
\hline & $(.369)$ & $(.629)$ & $(.314)$ & $(.258)$ & $(.515)$ & & & & & \\
\hline Forced Selection Entry & $1.462^{* * *}$ & $3.594 * * *$ & -.205 & .463 & .408 & & & & & \\
\hline & $(.706)$ & (1.296) & $(.512)$ & $(.459)$ & $(1.381)$ & & & & & \\
\hline Forced Selection $\times \log ($ Tenure $)$ & $-1.194 *$ & $-20.681 * * *$ & $1.148 * * *$ & -.094 & -.008 & & & & & \\
\hline & $(.676)$ & ( 1.466$)$ & $(.300)$ & $(.313)$ & $(.482)$ & & & & & \\
\hline Regular Entry & & & & & & & & & & \\
\hline Regular First-Election Entry & & & & & & -.594 & -1.654 & .172 & -.321 & -.670 \\
\hline & & & & & & $(.727)$ & $(1.221)$ & $(.529)$ & (.409) & (2.178) \\
\hline Regular First-Election $\times \log ($ Tenure $)$ & & & & & & .153 & .305 & $-1.071 * * *$ & -.015 & .189 \\
\hline & & & & & & $(.356)$ & $(.714)$ & $(.308)$ & $(.250)$ & $(.762)$ \\
\hline Regular Election Entry & & & & & & -.916 & -3.021 & -.320 & $-.839 * *$ & .437 \\
\hline & & & & & & $(.764)$ & $(2.132)$ & $(.469)$ & $(.368)$ & (1.099) \\
\hline Regular Election $\times \log ($ Tenure $)$ & & & & & & .452 & .966 & $-.509^{*}$ & $.520^{* *}$ & -.186 \\
\hline & & & & & & $(.411)$ & (1.019) & $(.303)$ & $(.248)$ & $(.392)$ \\
\hline Foreign Entry & -1.120 & 1.887 & -16.387 **** & -2.397 & $-13.576 * * *$ & -1.880 & -.564 & $-14.837 * * *$ & -3.070 & $-11.955 * * *$ \\
\hline & (1.686) & $(1.362)$ & $(.760)$ & (2.223) & (1.509) & (1.757) & $(.837)$ & $(.816)$ & $(2.168)$ & $(1.420)$ \\
\hline Foreign $\times \log ($ Tenure $)$ & .847 & -.028 & $1.154 * * *$ & .714 & -.715 & 1.137 & .613 & .361 & $1.037^{*}$ & -.750 \\
\hline & $(.829)$ & $(.744)$ & $(.402)$ & $(.643)$ & $(.503)$ & $(.876)$ & $(.662)$ & $(.415)$ & $(.620)$ & $(.519)$ \\
\hline Log(Tenure) & .125 & .299 & $-.866^{* * * *}$ & -.069 & .459 & -.141 & -.362 & -.083 & $-.337^{*}$ & .504 \\
\hline & $(.192)$ & $(.473)$ & $(.191)$ & $(.129)$ & $(.326)$ & $(.265)$ & $(.576)$ & $(.197)$ & $(.192)$ & $(.317)$ \\
\hline Controls & & & & & & & & & & \\
\hline $\ln (\mathrm{GDP} /$ capita $)$ & $-.354 * *$ & -.014 & -.204 & .122 & -.325 & $-.372 * * *$ & .022 & $-.224 *$ & .070 & -.369 \\
\hline & $(.138)$ & $(.159)$ & $(.127)$ & $(.139)$ & $(.219)$ & $(.135)$ & $(.163)$ & $(.130)$ & $(.141)$ & $(.226)$ \\
\hline GDP Growth & $-3.064 * * *$ & -1.291 & -.153 & -.522 & -.005 & $-3.176 * * *$ & -1.556 & -.152 & -.504 & -.013 \\
\hline & $(.850)$ & ( 1.755$)$ & (.633) & $(.775)$ & $(.181)$ & $(.866)$ & ( 1.733$)$ & $(.584)$ & $(.770)$ & $(.194)$ \\
\hline Military Dictatorship & -.147 & .032 & $.688^{*}$ & $.730 * * *$ & $.745^{*}$ & -.116 & -.007 & $.609 *$ & $.818 * * *$ & .689 \\
\hline & $(.399)$ & (.661) & $(.351)$ & $(.257)$ & $(.431)$ & $(.327)$ & $(.603)$ & $(.361)$ & $(.249)$ & $(.510)$ \\
\hline Monarchy & $-2.176^{* * *}$ & -.616 & -.287 & -.800 & $1.435^{\text {** }}$ & $-2.078 * * *$ & -.503 & -.360 & -.832 & $1.527^{* *}$ \\
\hline & $(.815)$ & $(.623)$ & $(.585)$ & $(.595)$ & $(.671)$ & $(.792)$ & $(.579)$ & $(.581)$ & $(.549)$ & $(.735)$ \\
\hline Party & $-2.108 * * *$ & -.444 & $-.688^{*}$ & $.993 * *$ & -.604 & $-2.042 * * *$ & -.334 & $-.684 * *$ & $.925^{* *}$ & -.528 \\
\hline & (.409) & $(.572)$ & $(.351)$ & $(.427)$ & $(.751)$ & $(.417)$ & $(.566)$ & $(.332)$ & $(.395)$ & $-.528(.835)$ \\
\hline Ln(Military Personnel) & -.152 & .085 & -.078 & .046 & .116 & $-.178^{*}$ & .055 & -.080 & .006 & .109 \\
\hline & $(.095)$ & $(.154)$ & $(.076)$ & $(.062)$ & $(.131)$ & $(.096)$ & $(.156)$ & $(.077)$ & $(.062)$ & $(.149)$ \\
\hline Civil War & $1.857 * * *$ & $.999 * *$ & .425 & .215 & -.716 & 1.867 *** & $.951 * *$ & .425 & .244 & -.691 \\
\hline & $(.272)$ & $(.473)$ & $(.347)$ & $(.232)$ & $(.536)$ & $(.275)$ & $(.483)$ & $(.350)$ & $(.232)$ & $(.539)$ \\
\hline War Victory & $-2.311^{*}$ & $-7.464 * *$ & -6.110 & -2.456 & $1.080^{*}$ & $-2.359^{*}$ & $-7.292 * *$ & -5.213 & -2.174 & $1.153^{* *}$ \\
\hline & (1.219) & $(3.261)$ & ( 4.083 ) & ( 1.539$)$ & (.619) & (1.206) & (3.162) & (3.701) & ( 1.330$)$ & $(.577)$ \\
\hline War Defeat & $1.011 * *$ & $3.608 * * *$ & .491 & -.178 & .679 & $.943^{*}$ & $3.310 * * *$ & .656 & -.108 & .757 \\
\hline & $(.482)$ & $(.647)$ & $(.733)$ & $(.675)$ & $(.568)$ & $(.515)$ & $(.626)$ & $(.730)$ & $(.660)$ & $(.528)$ \\
\hline War Draw & -.539 & -1.625 & -.787 & -.801 & .463 & -.538 & -1.330 & -.800 & -.806 & .445 \\
\hline & (.496) & $(1.241)$ & $(.626)$ & $(.651)$ & $(.605)$ & (.483) & (1.100) & $(.640)$ & (.659) & (.626) \\
\hline Age & $.039^{* * * *}$ & $.049 * *$ & $.022 * *$ & $.045^{* * * *}$ & $.067 * * *$ & $.041^{* * * *}$ & $.048 * *$ & $.024 * *$ & $.049 * * *$ & $.068^{* * * *}$ \\
\hline & $(.013)$ & $(.024)$ & $(.010)$ & $(.010)$ & $(.014)$ & $(.013)$ & $(.022)$ & $(.011)$ & $(.011)$ & $(.014)$ \\
\hline Constant & $-1.716^{*}$ & $-8.879^{* * *}$ & $-2.148^{* *}$ & $-7.600^{* * *}$ & $-7.795 * * *$ & -.969 & $-6.596^{* * * *}$ & $-2.025 *$ & $-6.702 * * *$ & $-7.637 * * *$ \\
\hline & $(.947)$ & $(1.942)$ & $(.988)$ & ( 1.118$)$ & ( 1.608$)$ & (1.002) & (1.659) & $(1.081)$ & $(.994)$ & (1.662) \\
\hline Log Likelihood & & & -1441.7293 & & & & & -1445.123 & & \\
\hline Observations & & & 3613 & & & & & 3613 & & \\
\hline
\end{tabular}

Note: Robust country-clustered standard errors are in parentheses. $* p<0.10$; $* * p<0.05$; *** $p<0.01$. We provide the first differences predicted from these models in Figure 2 and Table 7. 
Figure 3: Effect of Rebel and Regime-Change Coup Entry on Coalition-Competing Removal
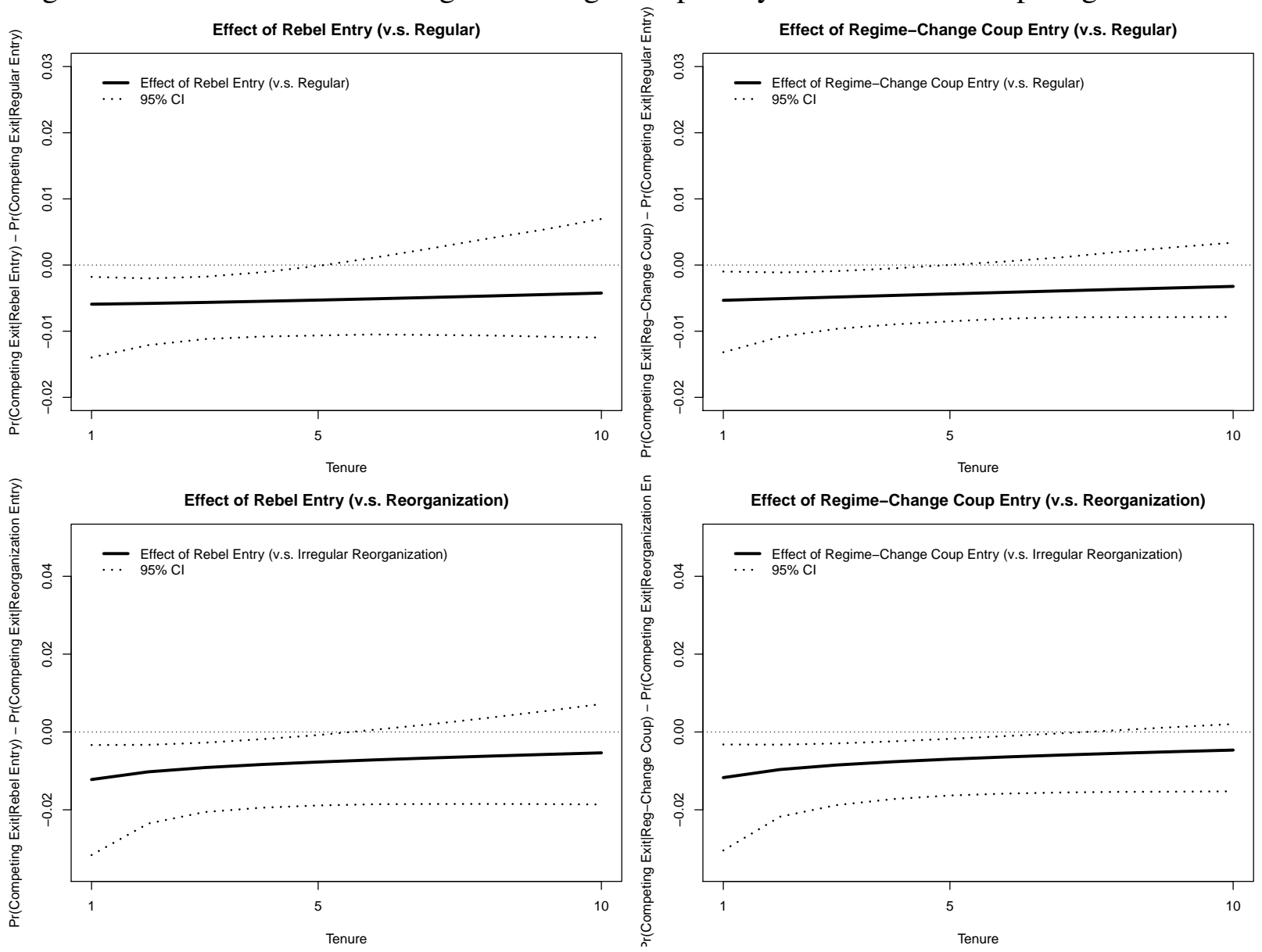

Note: We show the changes in predicted probabilities of coalition-competing removal when we change entry manner from regular or irregular reorganization entry to rebel or regime-change coup entry. We use Models 2 and 3 in Table 5 to estimate these first differences.

Figure 3 shows the changes in predicted probabilities of coalition-competing removal when we change entry manner from regular (the top panel) or irregular reorganization (the bottom panel) to rebel (the left panel) or regime-changing coup (the right panel). The effects of rebel entry and regime-changing coup entry look very similar and, as predicted by our first hypothesis, they are negative and significant during the first few years of a new leader's time in power. In other words, the coalition-competing removals are least likely to occur against leaders who took power through successful rebellions or major regime-changing coups. These stabilizing effects of the disaggregated forms of irregular regime replacement entry, though, gradually diminish and leader entry has no statistically significant effect on the risk of a coalitioncompeting exit once a leader has spent approximately 6-8 years in office. 
The results for the two forms of regular entry are also statistically indistinguishable from each other (coefficients of -.59 and .-92 in Model 3). There is a larger difference between the two forms of regime reorganization, but this is not surprising. Leaders entering through forced election/selection (coefficient of 1.46, Model 2) have a greater risk of a coalition-competing removal than those entering through a reshuffling coup (coefficient of 0.13 , Model 2) because reshuffles are responses to internal divisions while forced election/selection typically occurs when regimes are already threatened by burgeoning popular protests or insurgencies. Since many of these forced selections are desperate attempts to stave off an impending crisis, the very high risk of a subsequent coalition-competing challenge is to be expected.

The results also show that most leaders who enter through irregular regime replacement generally do not enjoy a similarly low risk of removal by coalition collapse or coalition circumvention. Leaders rising through rebellion are slightly less likely to suffer coalition collapse in their first year in power, though the statistical significance of this effect is relatively weak and derived from a small sample of leaders. Leaders entering through regime-changing coups are somewhat more likely than regular entry leaders to suffer coalition-circumventing forms of removal early in their tenures, but there is no similar effect vis-à-vis leaders who came to power through irregular reorganizations.

\section{Coup Entry and Coup Exit}

Our findings seemingly challenge the well-known "coup trap" hypothesis, which is the idea that a coup greatly increases the chances of a subsequent coup attempt (Londregan and Poole, 1990; Belkin and Schofer, 2003; Powell, 2012). This argument implies that leaders who enter office via coup are more likely to be removed via coup. In contrast, our analysis shows that leaders who come to power by a regime-changing coup are significantly less likely to fall in another regime-changing coup, especially in the first few years after they take power. Here, we show that we can reconcile these complementary findings.

Table 6 present the results from four slightly different logit models. Models 4 and 5 
Table 6: Logit Analysis of Coup Exit in Dictatorships

\begin{tabular}{|c|c|c|c|c|}
\hline Dependent Variable: & Model 4 & Model 5 & Model 6 & Model 7 \\
\hline $\begin{array}{l}\text { Dependent Variable: } \\
\text { Exit Manner }\end{array}$ & \multicolumn{2}{|c|}{ Regime-Change Coup } & \multicolumn{2}{|c|}{ Reshuffling-Coup } \\
\hline \multicolumn{5}{|l|}{ Base Category: } \\
\hline Independent Variables & & & & \\
\hline $\begin{array}{l}\text { Regime-Change Coup Entry } \\
\text { Regime-Change Coup } \times \log (\text { Tenure })\end{array}$ & $\begin{array}{c}-2.375^{* *} \\
(.924) \\
.394 \\
(.406)\end{array}$ & $\begin{array}{c}-1.767 * * \\
(.792)\end{array}$ & $\begin{array}{l}-.065 \\
(.556) \\
.150 \\
(.308)\end{array}$ & $\begin{array}{l}.099 \\
(.416)\end{array}$ \\
\hline Reshuffling Coup Entry & $\begin{array}{l}-.082 \\
(.785)\end{array}$ & $\begin{array}{l}.186 \\
(.609)\end{array}$ & $\begin{array}{l}.275 \\
(.505)\end{array}$ & $\begin{array}{l}.795 * * \\
(.363)\end{array}$ \\
\hline Reshuffling Coup $\times \log ($ Tenure $)$ & $\begin{array}{l}.215 \\
(.389)\end{array}$ & & $\begin{array}{l}.478 \\
(.293)\end{array}$ & \\
\hline $\log ($ Tenure $)$ & $\begin{array}{l}.178 \\
(.220)\end{array}$ & $\begin{array}{l}.265 \\
(.194)\end{array}$ & $\begin{array}{c}-.576 * * * \\
(.174)\end{array}$ & $\begin{array}{c}-.417 * * * \\
(.115)\end{array}$ \\
\hline Controls & & & & \\
\hline $\ln (\mathrm{GDP} /$ capita $)$ & $\begin{array}{c}-.509 * * * \\
(.188)\end{array}$ & $\begin{array}{c}-.520 * * * \\
(.190)\end{array}$ & $\begin{array}{l}-.225 \\
(.151)\end{array}$ & $\begin{array}{l}-.207 \\
(.158)\end{array}$ \\
\hline GDP Growth & $\begin{array}{l}-.319 \\
(1.088)\end{array}$ & $\begin{array}{c}-.372 \\
(1.129)\end{array}$ & $\begin{array}{l}-.365 \\
(.852)\end{array}$ & $\begin{array}{l}-.365 \\
(.953)\end{array}$ \\
\hline Military Dictatorship & $\begin{array}{l}-.169 \\
(.530)\end{array}$ & $\begin{array}{l}-.110 \\
(.529)\end{array}$ & $\begin{array}{c}.612 \\
(.388)\end{array}$ & $\begin{array}{l}.675^{*} \\
(.393)\end{array}$ \\
\hline Monarchy & $\begin{array}{c}-2.443 * * * \\
(.832)\end{array}$ & $\begin{array}{c}-2.429 * * * \\
(.829)\end{array}$ & $\begin{array}{l}-.240 \\
(.635)\end{array}$ & $\begin{array}{l}-.205 \\
(.630)\end{array}$ \\
\hline Party & $\begin{array}{c}-2.866 * * * \\
(.479)\end{array}$ & $\begin{array}{c}-2.860 * * * \\
(.488)\end{array}$ & $\begin{array}{l}-.823 * * \\
(.389)\end{array}$ & $\begin{array}{l}-.803 * * \\
(.373)\end{array}$ \\
\hline Ln(Military Personnel) & $\begin{array}{l}-.223^{*} \\
(.126)\end{array}$ & $\begin{array}{l}-.220^{*} \\
(.126)\end{array}$ & $\begin{array}{l}-.073 \\
(.088)\end{array}$ & $\begin{array}{l}-.075 \\
(.087)\end{array}$ \\
\hline Civil War & $\begin{array}{c}1.537 * * * \\
(.387)\end{array}$ & $\begin{array}{c}1.544 * * * \\
(.386)\end{array}$ & $\begin{array}{l}.483 \\
(.333)\end{array}$ & $\begin{array}{l}.474 \\
(.327)\end{array}$ \\
\hline War Victory & $\begin{array}{l}-2.124 \\
(1.536)\end{array}$ & $\begin{array}{l}-2.196 \\
(1.540)\end{array}$ & $\begin{array}{l}-4.991 \\
(4.808)\end{array}$ & $\begin{array}{l}-4.943 \\
(4.600)\end{array}$ \\
\hline War Defeat & $\begin{array}{l}.065 \\
(.972)\end{array}$ & $\begin{array}{l}.181 \\
(.905)\end{array}$ & $\begin{array}{l}.111 \\
(1.017)\end{array}$ & $\begin{array}{c}.091 \\
(1.013)\end{array}$ \\
\hline War Draw & $\begin{array}{c}-2.139 * * \\
(1.012)\end{array}$ & $\begin{array}{c}-2.107 * * \\
(1.011)\end{array}$ & $\begin{array}{l}-1.199 \\
(.769)\end{array}$ & $\begin{array}{l}-1.196 \\
(.777)\end{array}$ \\
\hline Age & $\begin{array}{l}.040 * * \\
(.019)\end{array}$ & $\begin{array}{l}.040 * * \\
(.018)\end{array}$ & $\begin{array}{l}.018 \\
(.011)\end{array}$ & $\begin{array}{c}.017 \\
(.011)\end{array}$ \\
\hline Constant & $\begin{array}{l}-.613 \\
(1.247)\end{array}$ & $\begin{array}{l}-.728 \\
(1.234)\end{array}$ & $\begin{array}{c}-2.239 * * \\
(1.081)\end{array}$ & $\begin{array}{c}-2.538^{* *} \\
(1.105)\end{array}$ \\
\hline Log Likelihood & -189.0286 & -189.41068 & -271.83226 & -272.8182 \\
\hline Observations & 3613 & 3613 & 3613 & 3613 \\
\hline
\end{tabular}

examine whether leaders entering through regime-changing and reshuffling coups face different risks of being overthrown in a regime-changing coup. Models 6 and 7 instead examine the effects of two types of coup entry on the risk of being overthrown in a reshuffling coup. To evaluate the substantive effect of each type of coup entry, we also calculate the first difference of the risk of being ousted via each type of coup when we change entry manner from non-coup entry to either regime-changing coup or reshuffling coup entry in Figures 4 and 5. 
The results in Table 6 show leaders who enter in a regime-changing coup are exceptionally unlikely to lose power in a regime-changing coup; the coefficients on Regime-Change Coup Entry (Models 4 and 5) are negative and significant. We illustrate this result in Figure 4). Meanwhile, leaders who enter in reshuffling coups are neither more nor less likely to suffer a regime-changing coup relative to leaders who entered in other ways (right panel of Figure 4. This finding rebukes the established wisdom regarding coup traps, at least as it applies to regime-changing coups.

Figure 4: Effect of Different Types of Coup Entry on Regime-Change Coup Exit
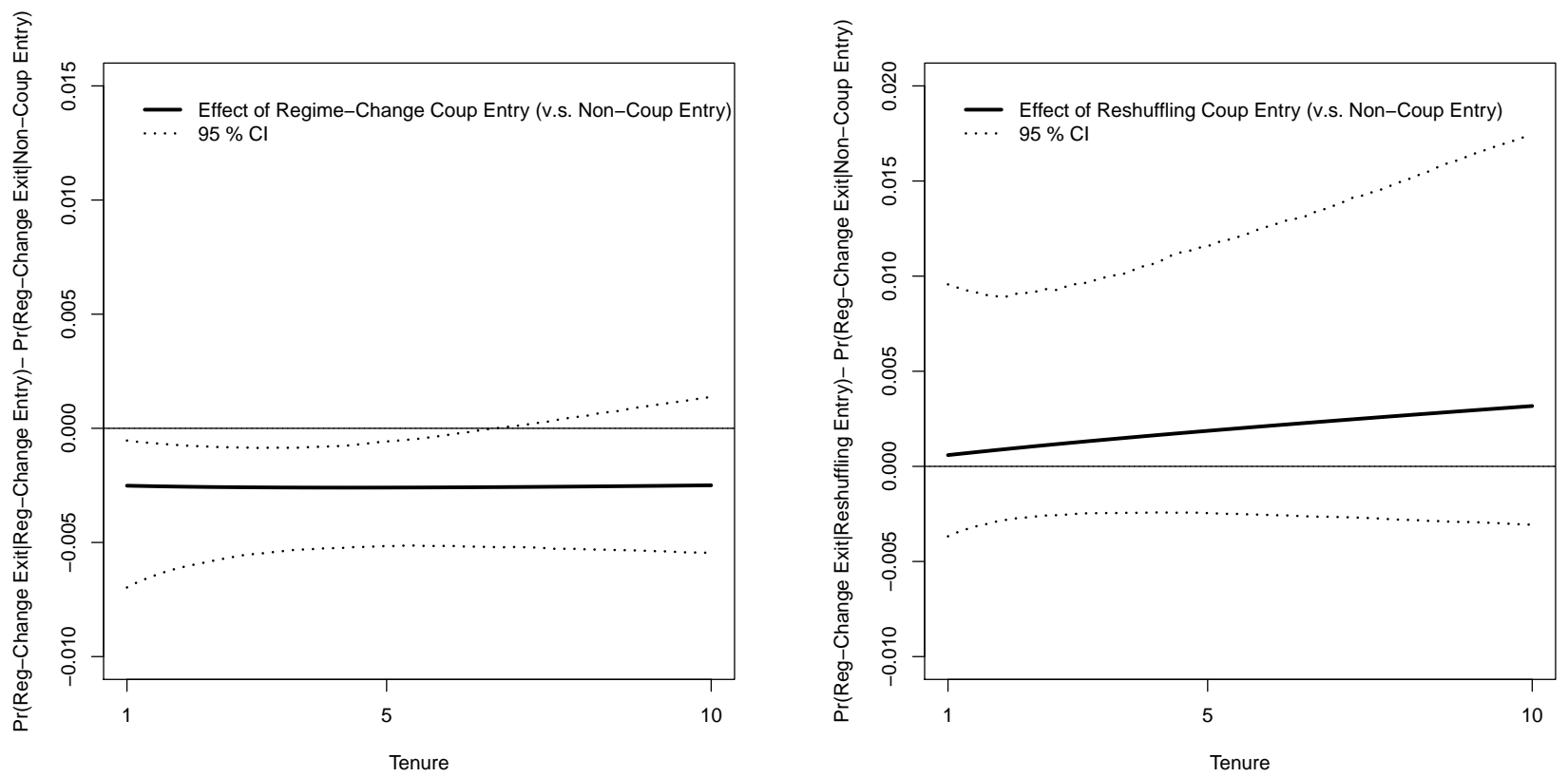

Note: We show the changes in predicted probabilities of regime-change coup removal when we change entry manner from non- coup entry to regime-change coup or reshuffling-coup entry. We use Models 4 in Table 6 to estimate the first difference.

But the same is not true of reshuffling coups (Models 6 and 7). Here, we see that while leaders entering in regime-changing coups are no more likely to fall in a reshuffling coup than leaders entering in a non-coup manner (See Figure 5, left), leaders who come to power in reshuffling coups are significantly more likely to suffer this type of threat (See Figure 5, right). Though the effect of reshuffling coup entry is insignificant in the first two years of leader tenure, it becomes positive and significant for the remainder of a leader's time in power (Figure 5 , right). 
Taken together, the results reported in this section reveal that while regime-changing coups deter subsequent regime-changing coups as our theory predicts, reshuffling coups encourage subsequent reshuffling coups. In accordance with prior literature, leaders who come to power via a reshuffling coup are significantly more likely to be overthrown via a reshuffling coup. By disaggregating coups by type, we find that the coup trap is the result of successive waves of reshuffling coups. Our argument is thus consistent with the coup trap argument; leaders who enter in major regime-changing coups are much less likely to be overthrown, yet the "coup trap" greatly increases the chances that leaders rising in reshuffling coups will be targeted by subsequent reshuffling coups.

Figure 5: Effect of Different Types of Coup Entry on Reshuffling Coup Exit
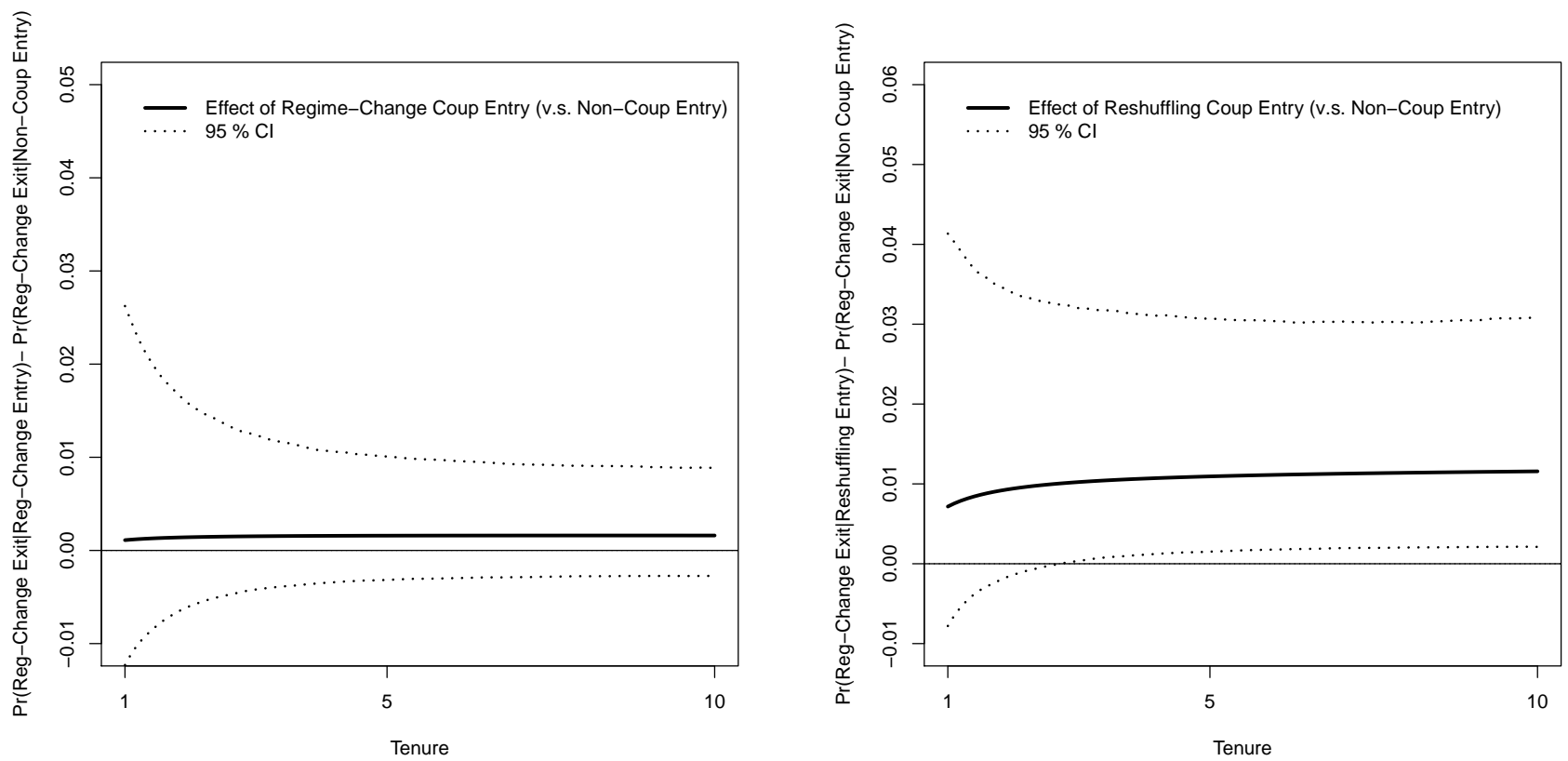

Note: We show the changes in predicted probabilities of reshuffling coup removal when we change entry manner from non- coup entry to regime-change coup or reshuffling-coup entry (Model 6, Table 6). 


\section{The Rise Predicts the Fall}

About $60 \%$ of the non-democratic leaders who come to power via coup, civil war, or protest are still in power three years later, and this rate is not significantly different than that for nondemocratic leaders who were elected or selected in regular constitutional processes. Yet, this similarity obscures an important difference: leaders with regular entries are more likely to be removed by rival coalitions while those who took power by removing their predecessor's entire governments were more likely to voluntarily resign. This provides some support for Machiavelli's observation that those who overcome the greatest difficulty in coming to power are those who have the least trouble keeping it. We show that this classical insight is consistent with the modern literatures on coordination and signaling; leaders who convey the strength of their supporting coalitions at the dawn of their tenures prove to be more resilient against similar challenges once in power.

Our analysis shows that after controlling for relevant political and economic factors, leaders who rise to power by coup, civil war, or protest are several times less likely to suffer these kinds of irregular regime changes compared to non-democratic leaders who came to power by other means. We claim the relative invulnerability enjoyed by these leaders is attributable to the show-of-strength that occurs when a new leader takes office with the explicit support of a strong, loyal, and risk-acceptant coalition of supporters. This demonstration of support helps leaders deter potential threats more effectively than leaders who came to power in ways that do not convey a strong coalition.

Beyond our core finding linking coordinated irregular entry to a lower risk of similar types of leader removal, the paper highlights what we can learn by looking beyond the constitutionality of non-democratic leader transitions and focusing more on the causes and consequences of specific forms of transition. We show that some forms of entry more explicitly convey the level of support a new incumbent enjoys, and we have also shown that some types of challenges are more sensitive to this kind of information. These insights should allow for more accurate predictions of war and coup in at-risk states, and they should also improve our 
understanding of how dictators choose to placate or repress political opposition. Future work could continue to refine this argument and consider factors that were not included in this study, such as how ethnic cleavages or the level of violence in a previous transition might affect subsequent political stability. If some entry types deter challenges, then leader entry could also affect levels of repression and concessions including public goods provision and political reform.

\section{References}

Acemoglu, Daron and James A. Robinson. 2006. Economic Origins of Dictatorship and Democracy. New York: Cambridge University Press.

Aksoy, Deniz, David. Carter and Joseph Wright. 2015. "Terrorism and the Fate of Dictators." World Politics 67(3):423-468.

Alesina, Alberto, Sule Özler, Nouriel Roubini and Phillip Swagel. 1996. "Political Instability and Economic Growth.” Journal of Economic Growth 1(2):189-211.

Ames, Barry. 1987. Political Survival: Politicians and Public Policy in Latin America. Berkeley: University of California Press.

Barro, Robert J. 1991. "Economic Growth in a Cross-Section of Countries." Quarterly Journal of Economics 106(2):407-443.

Beaulieu, Emily and Susan D. Hyde. 2009. "In the Shadow of Democracy Promotion: Strategic Manipulation, International Observers, and Election Boycotts." Comparative Political Studies 42(3):392-415.

Belkin, Aaron and Evan Schofer. 2003. "Toward a Structural Understanding of Coup Risk.” Journal of Conflict Resolution 47(5):594-620.

Bell, Curtis. 2011. "Buying Support and Buying Time: The Effect of Regime Consolidation on Public Goods Provision." International Studies Quarterly 55(3):625-646.

Boix, Carles. 2003. Democracy and Redistribution. New York: Cambridge University Press.

Boix, Carles and Milan W. Svolik. 2013. "The Foundations of Limited Authoritarian Government: Institutions, Commitment, and Power-Sharing in Dictatorships." Journal of Politics 75(2):300-316.

Bolt, Jutta and Jan Luiten van Zanden. 2014. "The Maddison Project: Collaborative Research on Historical National Accounts.” The Economic History Review 67(3):627-651.

Brecher, Michael and Jonathan Wilkenfeld. 2000. A Study of Crisis. Ann Arbor, MI: University of Michigan Press.

Brown, David S. and Ahmed Mushfiq Mobarak. 2009. "The Transforming Power of Democracy: Regime Type and the Distribution of Electricity." American Political Science Review 103(2):193-213.

Brownlee, Jason. 2007. “Hereditary Succession in Modern Autocracies.” World Politics 59(4):595-628. 
Bueno de Mesquita, Bruce and Alastair Smith. 2015. "Political Succession: A Model of Coups, Revolution, Purges, and Everyday Politics." Journal of Conflict Resolution Forthcoming.

Bueno de Mesquita, Bruce, Alastair Smith, Randolph M. Siverson and James D. Morrow. 2003. The Logic of Political Survival. Cambridge, MA: MIT Press.

Campos, Nauro F. and Jeffrey B. Nugent. 2002. "Who is Afraid of Political Instability?" Journal of Development Economics 67:157-172.

Casper, Brett Allen and Scott A. Tyson. 2014. "Popular Protest and Elite Coordination in a Coup d'État." Journal of Politics 76(2):548-564.

Cheibub, Jose Antonio, Jennifer Gandhi and James Raymond Vreeland. 2010. "Democracy and Dictatorship Revisited." Public Choice 143(1):67-101.

Chiozza, Giacomo and H. E. Goemans. 2011. Leaders and International Conflict. New York: Cambridge University Press.

Cho, In-Koo and David M. Kreps. 1987. "Signaling Games and Stable Equilibria." The Quarterly Journal of Economics 102(2):179-221.

Collier, Paul, V.L. Elliott, Havard Hegre, Anke Hoeffler, Marta Reynal-Querol and Nicholas Sambanis. 2003. Breaking the Conflict Trap: Civil War and Development Policy. Washington: World Bank.

Conrad, Courtenay R. 2011. "Constrained Concessions: Beneficent Dictatorial Responses to the Domestic Political Opposition.” International Studies Quarterly 55(4):1167-1187.

Daxecker, Ursula E. 2014. "All Quiet on Election Day? International Election Observation and Incentives for Pre-Election Violence in African Elections.” Electoral Studies 34:232-243.

Deacon, Robert T. 2009. “Public Good Provision under Dictatorship and Democracy.” Public Choice 139:241-262.

Debs, Alexandre and Henk E. Goemans. 2010. "Regime Type, the Fate of Leaders, and War." American Political Science Review 104(3):430-445.

Edmond, Chirs. 2013. "Information Manipulation, Coordination, and Regime Change." The Review of Economic Studies 80(4):1422-1458.

Ellis, Cali Mortenson, Michael C. Horowitz and Allan C. Stam. 2015. "Introducing The LEAD Data Set." International Interactions 41(4):718-741.

Feng, Yi. 1997. "Democracy, Political Stability, and Economic Growth." British Journal of Political Science 27(3):391-418.

Fosu, Augustin Kwasi. 2002. "Political Instability and Economic Growth: Implications of Coup Events in sub-Saharan Africa." American Journal of Economics and Sociology 61(1):329-348.

Gandhi, Jennifer. 2008. Political Institutions under Dictatorship. New York: Cambridge University Press.

Gandhi, Jennifer and Adam Przeworski. 2007. "Authoritarian Institutions and the Survival of Autocrats." Comparative Political Studies 40(11):1279-1301. 
Geddes, Barbara. 1999. "What Do We Know About Democratization After Twenty Years?" Annual Review of Political Science 2(1):115-144.

Geddes, Barbara. 2003. Paradigms and Sand Castles: Theory Building and Research Design in Comparative Politics. Ann Arbor: University of Michigan Press.

Gleditsch, Kristian Skrede and Andrea Ruggeri. 2010. "Political Opportunity Structures, Democracy, and Civil War." Journal of Peace Research 47(3):299-310.

Gleditsch, Nils Petter, Peter Wallensteen, Mikael Eriksson, Margareta Sollenberg and Havard Strand. 2002. “Armed Conflict 1946-2001: A New Dataset." Journal of Peace Research 39:615-637.

Goemans, Henk E. 2008. "Which Way Out? The Manner and Consequences of Losing Office." Journal of Conflict Resolution 52(6):771-794.

Goemans, Henk E., Kristian Skrede Gleditsch and Giacomo Chiozza. 2009. "Introducing Archigos: A Dataset of Political Leaders.” Journal of Peace Research 46(2):269-283.

González-Ocantos, Ezequiel, Chad Kiewiet de Jonge and David W. Nickerson. 2015. "Legitimacy Buying: The Dynamics of Clientelism in the Face of Legitimacy Challenges." Comparative Political Studies 48(9):1127-1158.

Gupta, Dipak K. 1990. The Economics of Political Violence: The Effect of Political Instability on Economic Growth. New York: Praeger Publications.

Huntington, Samuel P. 1968. Political Order in Changing Societies. New Haven, CT: Yale.

Igbal, Zaryab and Christopher Zorn. 2008. "The Political Consequences of Assassination." Journal of Conflict Resolution 52(3):385-400.

Jones, Benjamin F. and Benjamin A. Olken. 2005. "Do Leaders Matter? National Leadership and Growth Since World War II." Quarterly Journal of Economics 120(3):835-864.

Jones, Benjamin F. and Benjamin A. Olken. 2009. "Hit or Miss? The Effect of Assassinations on Institutions and War." American Economic Journal: Macroeconomics 1(2):55-87.

Jong-A-Pin, Richard. 2009. "On the Measurement of Political Instability and its Impact on Economic Growth.” European Journal of Political Economy 25(1):15-29.

Karklins, Rasma and Roger Peterson. 1993. "Decision Calculus of Protesters and Regimes: Eastern Europe 1989." Journal of Politics 55(3):588-614.

Keefer, Philip. 2007. "Clientelism, Credibility, and the Policy Choices of Young Democracies." American Journal of Political Science 51(4):804-821.

Kokkonen, Andrej and Anders Sundell. 2014. "Delivering Stability: Primogeniture and Autocratic Survival in European Monarchies, 1000-1800.” American Political Science Review 108(2):438-453.

Kuran, Timur. 1989. "Sparks and Prairie Fires: A Theory of Unanticipated Political Revolution.” Public Choice 61(1):41-74.

Kuran, Timur. 1991. "Liberalization and Democratization in the Soviet Union and Eastern Europe." World Politics 44(1):7-48. 
Kurrild-Klitgaard, Peter. 2000. "The Constitutional Economics of Autocratic Succession.” Public Choice 103(1):63-84.

Lake, David A. and Matthew A. Baum. 2001. "The Invisible Hand of Democracy: Political Control and the Provision of Public Services." Comparative Political Studies 34(6):587-621.

Lehoucq, Fabrice and Aníbal Pérez-Linán. 2014. "Breaking Out of the Coup Trap: Political Competition and Military Coups in Latin America." Comparative Political Studies 47(8):1105-1129.

Levitsky, Steven and Lucan A. Way. 2010. Competitive Authoritarianism: Hybrid Regimes after the Cold War. New York: Cambridge University Press.

Little, Andrew T. 2015. "Coordination, Learning, and Coups." Journal of Conflict Resolution OnlineFirst.

Lohmann, Susanne. 1993. "A Signaling Model of Informative and Manipulative Political Action." American Political Science Review 87(2):319-333.

Lohmann, Susanne. 1994. "The Dynamics of Informational Cascades: The Monday Demonstrations in Leipzig, East Germany, 1989-91.” World Politics 47(1):42-101.

Londregan, John B. and Keith T. Poole. 1990. "Poverty, the Coup Trap, and the Seizue of Executive Power." World Politics 42(2):151-183.

Magaloni, Beatriz. 2008. "Credible Power-Sharing and the Longevity of Authoritarian Rule." Comparative Political Studies 41(4-5):715-741.

Miller, Michael K. 2012. "Economic Development, Violent Leader Removal, and Democratization." American Journal of Political Science 56(4):1002-1020.

Min, Brian. 2015. Power and the Vote: Elections and Electricity in the Developing World. New York: Cambrdige University Press.

Olson, Mancur. 1993. "Dictatorship, Democracy, and Development." American Political Science Review 87(3):567-576.

Powell, Jonathan. 2012. "Determinants of the Attempting and Outcome of Coups d'État." Journal of Conflict Resolution 56(6):1017-1040.

Ross, Michael. 2006. "Is Democracy Good for the Poor?" American Journal of Political Science 50(4):860-874.

Schedler, Andreas. 2006. Electoral AutAuthoritarian: The Dynamics of Unfree Competition. Boulder, CO: Lynne Rienner.

Schedler, Andreas. 2013. The Politics of Uncertainty: Sustaining and Subverting Electoral Authoritarianism. London: Oxford University Press.

Singer, J. David. 1987. "Reconstructing the Correlates of War Dataset on Material Capabilities of States, 1816-1985." International Internations 14:115-132.

Smith, Benjamin. 2005. "Life of the Party: The Origins of Regime Breakdown and Persistence under Single-Party Rule.” World Politics 57(3):421-451. 
Sudduth, Jun Koga. 2017. "Strategic Logic of Elite Purges in Dictatorships." Comparative Political Studies. Available Online, February 2017.

Svolik, Milan. 2008. "Authoritarian Reversals and Democratic Consolidation.” American Political Science Review 102(2):153-168.

Svolik, Milan and Seden Akcinaroglu. 2007. "Government Change in Authoritarian Regimes Codebook.".

Svolik, Milan W. 2009. "Power Sharing and Leadership Dynamics in Authoritarian Regimes." American Journal of Political Science 53(2):477-494.

Svolik, Milan W. 2012. The Politics of Authoritarian Rule. New York: Cambridge University Press.

Themnér, Lotta and Peter Wallensteen. 2012. "Armed Conflict, 1946-2011.” Journal of Peace Research 49(4):565-575.

Thyne, Clayton L., Jonathan M. Powell, Sarah Hayden and Emily VanMeter. 2014. "The Influence of Post-Coup Signals on Regime Survival." Unpublished . 
Supporting Appendix A: Our Dataset and Coding Criteria 
This dataset codes eight forms of leader entry according to the following coding tree:

1. Did the ruling political regime choose the new leader or agree to the process for leader selection?

YES 1a. Was this decision a response to an unexpected political crisis brought on by regime opponents, such as an assassination, protest, or war?

YES Code as Forced Election/Selection. Leaders here should include those entering after assassinations, those appointed by the regime in response to protests, etc. but should not include leaders that were not explicitly chosen by the predecessor or the appropriate officials within the predecessor's ruling regime.

NO 1b. Was this the first transition between individual leaders within the predecessor's regime (unprecedented), or was the predecessor the most recent of multiple leaders to have served under the existing ruling order (unprecedented)?

PRECEDENTED Code as Regular Election/Selection. Leaders here should include those were (s)elected under long-established dominant party systems, successors in established hereditary monarchies, etc. This code should not be applied to leaders who took power in systems that did not have established patterns/norms of leader transition.

UNPRECEDENTED Code as First Regular Transition. This category encompasses the leaders who come to power within a regime that has not yet established precedented patterns for leader transition. The first leaders to succeed regime founders (e.g. Raul Castro) or those who come to power in a regime's first elections (e.g. Francois Duvalier) belong in this category.

NO 2. The new leader was forced upon the predecessor's government by:

A FOREIGN GOVERNMENT Code as Foreign Installation. Leaders belong in this category if foreign governments were the most important actors in the leader transition. Foreign support for rebel groups or coup plotters is not sufficient. Typically, the foreign role will be much greater in these cases (e.g. Castillo Armas in Guatemala, 1957 or Harmid Karzai in Afghanistan, 2001).

COUP CONSPIRATORS 2a. Did the coup plotters seek to replace the leader while mostly preserving existing regime norms and institutions?

YES Code as Reshuffle Coup. Sometimes called "shuffling coups," these are transitions in which conspirators put a new individual in charge of the existing order. These are less likely to bloody coups.

NO Code as Regime-Change Coup. These transitions occur when entire political regimes are removed and replaced. In addition to leader replacement, the successful coup plotters significantly change institutions and the nature of executive power in the country.

A MASS MOVEMENT 2b. Did the movement achieve a military victory over the government?

YES Code as Successful Rebellion. This category should include only leaders who were chosen by successful rebels after a military campaign against the government. Leaders chosen by the ruling regime in response to an increasingly threatening rebellion should be coded as Irregular Election/Selection because the predecessor's government selected the new leader.

NO Code as Successful Protest. This category should include only leaders who were chosen by successful protesters/strikers after a non-militarized campaign against the government. Leaders chosen by the ruling regime in response to an increasingly threatening protest should be coded as Irregular Election/Selection because the predecessor's government selected the new leader. 
This dataset codes eight forms of leader exit according to the following coding tree:

1. Did the leader die a natural death in office?

YES Code as Natural Death.

NO See Question 2.

2 Was the leader assassinated outside the context of a larger coup conspiracy or political conflict?

YES Code as Assassination. Note that killings that occur as a result of bloody coups or rebel victories should be coded elsewhere.

NO See Question 3.

3. Was the leader forced out by an immediate political crisis, or did the leader resign voluntarily?

RESIGNED Code as Voluntary Resignation. These usually occur with elections, successions, and abdications that are not immediate responses to major political crises.

FORCED 4. The leader was forced out primarily by:

A FOREIGN GOVERNMENT Code as Foreign Overthrow. Leaders belong in this category if foreign governments were the most important actors in the leader transition. Foreign support for rebel groups or coup plotters is not sufficient. Typically, the foreign role will be much greater in these cases (e.g. Hussein in Iraq, 2003).

COUP CONSPIRATORS 4a. Did the coup plotters seek to replace the leader while mostly preserving existing regime norms and institutions?

YES Code as Reshuffle Coup. Sometimes called "shuffling coups," these are transitions in which conspirators put a new individual in charge of the existing order. These are less likely to be bloody coups.

NO Code as Regime-Change Coup. These transitions occur when entire political regimes are removed and replaced. In addition to leader replacement, the successful coup plotters significantly change institutions and the nature of executive power in the country.

A MASS MOVEMENT 4b. Did the movement coerce the government through military force?

YES Code as Rebellion. This category should include only leaders who were forced out during a rebel campaign against the government.

NO Code as Protest. This category should include only leaders who were forced out by protesters/strikers after a non-militarized campaign against the government.

A LEGAL PROCESS Code as Legal Removal. Constitutional impeachments, involuntary removals by juntas or politburos (via legal deliberations rather than secretive coups), etc. qualify here. For these to not be counted as Voluntary Resignations, there needs to be strong evidence that the leader was removed by an unusual and legal process (i.e. not a Leader Coup) against her wishes. 


\begin{tabular}{crrl} 
leadercode & ccode & \multicolumn{1}{l}{ smonth } & \multicolumn{2}{l}{ syear leader } \\
40001 & 40 & 3 & 1952 Batista \\
40002 & 40 & 1 & 1959 Castro \\
40003 & 40 & 2 & 2008 Raul Castro \\
41001 & 41 & 5 & 1950 Magloire \\
41002 & 41 & 12 & 1956 Pierre-Louis \\
41003 & 41 & 2 & 1957 Sylvain \\
41004 & 41 & 4 & 1957 Executive Council \\
41005 & 41 & 5 & 1957 Cantave \\
41006 & 41 & 5 & 1957 Fignole \\
41007 & 41 & 6 & 1957 Kebreau \\
41008 & 41 & 10 & 1957 Duvalier, Francois \\
41009 & 41 & 4 & 1971 Duvalier, Jean- \\
41010 & 41 & 2 & 1986 Namphy \\
41011 & 41 & 2 & 1988 Manigat \\
41012 & 41 & 6 & 1988 Namphy \\
41013 & 41 & 9 & 1988 Avril \\
41014 & 41 & 3 & 1990 Pascal-Troillet \\
41015 & 41 & 9 & 1991 Cedras \\
41016 & 41 & 2 & 2001 Aristide \\
41017 & 41 & 2 & 2004 Boniface Alexandre \\
42001 & 42 & 5 & 1961 Balaguer \\
42002 & 42 & 1 & 1962 Filiberto Bonnelly \\
42003 & 42 & 9 & 1963 de los Santos \\
42004 & 42 & 12 & 1963 Cabral \\
42005 & 42 & 4 & 1965 Bartolome Benoit \\
42006 & 42 & 5 & 1965 Imbert \\
42007 & 42 & 9 & 1965 Godoy \\
42008 & 42 & 7 & 1966 Balaguer \\
55001 & 55 & 3 & 1979 Maurice Bishop \\
55002 & 55 & 10 & 1983 Hudson Austin \\
55003 & 55 & 12 & 1983 Nicholas Brathwaite \\
70001 & 70 & 12 & 1952 Ruiz Cortines \\
70002 & 70 & 12 & 1958 Lopez Mateos \\
70003 & 70 & 12 & 1964 Diaz Ordaz \\
70004 & 70 & 12 & 1970 Echeverria Alvarez \\
70005 & 70 & 12 & 1976 Lopez Portillo \\
70006 & 70 & 12 & 1982 de La Madrid \\
70007 & 70 & 12 & 1988 Salinas \\
70008 & 70 & 12 & 1994 Zedillo \\
90001 & 90 & 6 & 1954 Monzon \\
90002 & 90 & 7 & 1954 Castillo Armas \\
90003 & 90 & 7 & 1957 Gonzalez Lopez \\
90004 & 90 & 10 & 1957 Flores Avendano \\
90005 & 90 & 3 & 1958 Ydigoras Fuente \\
90006 & 90 & 3 & 1963 Peralta Azurdia \\
90007 & 90 & 7 & 1966 Mendez Montenegro \\
90008 & 90 & 7 & 1970 Arana Osorio \\
90009 & 90 & 7 & 1974 Laugerud Garcia \\
90010 & 90 & 7 & 1978 Lucas Garcia \\
90011 & 90 & 3 & 1982 Rios Montt \\
90012 & 90 & 8 & 1983 Mejia Victores \\
90013 & 90 & 1 & 1986 Cerezo \\
90014 & 90 & 1 & 1991 Serrano Elias \\
90015 & 90 & 6 & 1993 Leon Carpio \\
& & &
\end{tabular}

\begin{tabular}{|c|c|c|c|c|c|}
\hline \multirow[t]{2}{*}{ emonth } & eyear & entry & exit & archigosentry & archigosexit \\
\hline & 1959 & 959 Regime-Change Coup & Rebellion & Irregular & Rebellion \\
\hline 2 & 2008 & 008 Successful Rebellion & Resignation, Health & Irregular & Retired Due to III Health \\
\hline & & First Election/Selection & Still in Power & & Still in Office \\
\hline 12 & & 956 Regime-Change Coup & Reshuffle Coup & Regular & Military Coup \\
\hline 2 & 1957 & 957 Reshuffle Coup & Protest & Regular & Military Coup \\
\hline 4 & 1957 & 957 Forced Election/Selection & Reshuffle Coup & Regular & Military Coup \\
\hline 5 & 1957 & 957 Reshuffle Coup & Reshuffle Coup & Regular & Regular \\
\hline 5 & 1957 & 957 Reshuffle Coup & Protest & Irregular & Military Coup \\
\hline 6 & 1957 & 957 Forced Election/Selection & Regime-Change Coup & Irregular & Military Coup \\
\hline 10 & & 957 Regime-Change Coup & Voluntary Resignation & Irregular & Regular \\
\hline 4 & 1971 & 971 First Election/Selection & Natural Death & Regular & Natural Death \\
\hline 2 & 1986 & 986 Regular Election/Selection & Regime-Change Coup & Regular & Military Coup \\
\hline 2 & 1988 & 988 Regime-Change Coup & Voluntary Resignation & Irregular & Regular \\
\hline 6 & 1988 & 988 First Election/Selection & Reshuffle Coup & Regular & Military Coup \\
\hline 9 & 1988 & 988 Reshuffle Coup & Regime-Change Coup & Irregular & Military Coup \\
\hline 3 & 1990 & 990 Regime-Change Coup & Protest & Irregular & Protest \\
\hline 2 & 1991 & 991 Forced Election/Selection & Voluntary Resignation & Regular & Regular \\
\hline 10 & & 994 Regime-Change Coup & Foreign Overthrow & Irregular & Foreign \\
\hline 2 & 2004 & 004 First Election/Selection & Rebellion & Regular & Rebellion \\
\hline 5 & 2006 & 006 Forced Election/Selection & Voluntary Resignation & Regular & Regular \\
\hline 1 & 1962 & 962 Forced Election/Selection & Regime-Change Coup & Irregular & Military Coup \\
\hline 2 & 1963 & 963 Forced Election/Selection & Voluntary Resignation & Regular & Regular \\
\hline 12 & & 963 Regime-Change Coup & Voluntary Resignation & Irregular & Regular \\
\hline 4 & 1965 & 965 First Election/Selection & Regime-Change Coup & Irregular & Military Coup \\
\hline 5 & 1965 & 965 Regime-Change Coup & Foreign Overthrow & Irregular & Regular \\
\hline 8 & 1965 & 965 Foreign Installation & Voluntary Resignation & Irregular & Regular \\
\hline 7 & 1966 & 966 Forced Election/Selection & Voluntary Resignation & Regular & Regular \\
\hline 7 & 1978 & 978 First Election/Selection & Voluntary Resignation & Regular & Regular \\
\hline 10 & & 983 Reshuffle Coup & Reshuffle Coup & NA & NA \\
\hline 10 & & 983 Reshuffle Coup & Foreign Overthrow & NA & NA \\
\hline 12 & & 984 Foreign Installation & Voluntary Resignation & Regular & Regular \\
\hline 12 & & 958 Regular Election/Selection & Voluntary Resignation & Regular & Regular \\
\hline 12 & & 964 Regular Election/selection & Voluntary Resignation & Regular & Regular \\
\hline 12 & & 970 Regular Election/Selection & Voluntary Resignation & Regular & Regular \\
\hline 12 & & 976 Regular Election/Selection & Voluntary Resignation & Regular & Regular \\
\hline 12 & & 982 Regular Election/Selection & Voluntary Resignation & Regular & Regular \\
\hline 12 & & 988 Regular Election/Selection & Voluntary Resignation & Regular & Regular \\
\hline 11 & & 994 Regular Election/Selection & Voluntary Resignation & Regular & Regular \\
\hline 11 & & 000 Regular Election/Selection & Voluntary Resignation & Regular & Regular \\
\hline 7 & 1954 & 954 Regime-Change Coup & Foreign Overthrow & Irregular & Removed by Military Power Struggle \\
\hline 7 & 1957 & 957 Foreign Installation & Assassination & Irregular & Assassination by Unsupported Individual \\
\hline 10 & & 957 Forced Election/Selection & Regime-Change Coup & Irregular & Military Coup \\
\hline 3 & 1958 & 958 Regime-Change Coup & Voluntary Resignation & Irregular & Regular \\
\hline 3 & 1963 & 963 First Election/Selection & Regime-Change Coup & Regular & Military Coup \\
\hline 7 & 1966 & 966 Regime-Change Coup & Voluntary Resignation & Irregular & Regular \\
\hline 7 & 1970 & 970 First Election/Selection & Voluntary Resignation & Regular & Regular \\
\hline 7 & 1974 & 974 Regular Election/Selection & Voluntary Resignation & Regular & Regular \\
\hline 7 & 1978 & 978 Regular Election/Selection & Voluntary Resignation & Regular & Regular \\
\hline 3 & 1982 & 982 Regular Election/Selection & Reshuffle Coup & Regular & Military Coup \\
\hline 8 & 1983 & 983 Reshuffle Coup & Reshuffle Coup & Irregular & Military Coup \\
\hline 1 & 1986 & 986 Reshuffle Coup & Voluntary Resignation & Irregular & Regular \\
\hline 1 & 1991 & 991 First Election/Selection & Voluntary Resignation & Regular & Regular \\
\hline 5 & 1993 & 993 Regular Election/Selection & Reshuffle Coup & Regular & Military Coup \\
\hline 1 & 1996 & 996 Forced Election/Selection & Voluntary Resignation & Irregular & Regular \\
\hline
\end{tabular}




$\begin{array}{rrrl}91001 & 91 & 11 & 1954 \text { Lozano Diaz } \\ 91002 & 91 & 10 & 1956 \text { Hector Caraccioli } \\ 91003 & 91 & 10 & 1963 \text { Lopez Arellano } \\ 91004 & 91 & 12 & 1972 \text { Lopez Arellano } \\ 91005 & 91 & 4 & 1975 \text { Melgar Castro } \\ 91006 & 91 & 8 & 1978 \text { Paz Garcia } \\ 92001 & 92 & 9 & 1950 \text { Osorio } \\ 92002 & 92 & 9 & 1956 \text { Lemus } \\ 92003 & 92 & 10 & 1960 \text { Castillo } \\ 92004 & 92 & 1 & 1961 \text { Portillo } \\ 92005 & 92 & 1 & 1962 \text { Rodolfo Cordon } \\ 92006 & 92 & 7 & 1962 \text { Rivera } \\ 92007 & 92 & 7 & 1967 \text { Sanchez Hernandez } \\ 92008 & 92 & 7 & 1972 \text { Molina } \\ 92009 & 92 & 7 & 1977 \text { Romero Mena } \\ 92010 & 92 & 10 & 1979 \text { Majano Ramos } \\ 92011 & 92 & 12 & 1980 \text { Duarte } \\ 92012 & 92 & 5 & 1982 \text { Magana Borjo } \\ 93001 & 93 & 9 & 1956 \text { Luis Somoza Debayle } \\ 93002 & 93 & 5 & 1963 \text { Shick Gutierrez } \\ 93003 & 93 & 8 & 1966 \text { Guerrero Gutierrez } \\ 93004 & 93 & 5 & 1967 \text { Anastasio Somoza Debayle } \\ 93005 & 93 & 7 & 1979 \text { Daniel Ortega } \\ 95001 & 95 & 5 & 1951 \text { Arosomena, A. } \\ 95002 & 95 & 10 & 1952 \text { Remon Cantero } \\ 95003 & 95 & 1 & 1955 \text { Guizado } \\ 95004 & 95 & 1 & 1955 \text { Arias Espinosa } \\ 95005 & 95 & 10 & 1956 \text { Guardia Jr., E. } \\ 95006 & 95 & 10 & 1968 \text { Torrijos Herrera } \\ 95007 & 95 & 7 & 1981 \text { Florez Aguilar } \\ 95008 & 95 & 3 & 1982 \text { Dario Paredes } \\ 95009 & 95 & 8 & 1983 \text { Noriega } \\ 100001 & 100 & 8 & 1950 \text { Laureanco Gomez } \\ 100002 & 100 & 11 & 1951 \text { Roberto Urdaneta Arbelaez } \\ 100003 & 100 & 6 & 1953 \text { Rojas Pinillia } \\ 100004 & 100 & 5 & 1957 \text { Paris } \\ 101001 & 101 & 11 & 1950 \text { Perez Jimenez } \\ 101002 & 101 & 3 & 2013 \text { Nicolas Maduro } \\ 110001 & 110 & 5 & 1966 \text { Burnham } \\ 110002 & 110 & 8 & 1985 \text { Hoyte } \\ 115001 & 115 & 11 & 1975 \text { Ferrier } \\ 115002 & 115 & 2 & 1980 \text { Bouterse } \\ 115003 & 115 & 12 & 1990 \text { Kraag } \\ 130001 & 130 & 7 & 1963 \text { Castro } \\ 130002 & 130 & 3 & 1966 \text { Yerovi Indaburu } \\ 130003 & 130 & 11 & 1966 \text { Arosemena Gomez } \\ 130004 & 130 & 2 & 1972 \text { Rodriguez Lara } \\ 130005 & 130 & 1 & 1976 \text { Poveda Burbano } \\ 135001 & 135 & 6 & 1950 \text { Noriega } \\ 135002 & 135 & 7 & 1950 \text { Odria } \\ 135003 & 135 & 7 & 1962 \text { Perez Godoy } \\ 135004 & 135 & 3 & 1963 \text { Lindley Lopez } \\ 135005 & 135 & 10 & 1968 \text { Velasco Alvarado } \\ 135006 & 135 & 8 & 1975 \text { Morales Bermudez } \\ 135007 & 135 & 11 & 2000 \text { Valentin Paniagua } \\ & & & \end{array}$

1956 Regular Election/Selection 1957 Regime-Change Coup 1971 Reshuffle Coup 1975 Reshuffle Coup 1978 Reshuffle Coup 1982 Reshuffle Coup
1956 First Election/Selection 1956 First Election/Selection 1961 Reshuffle Coup 1962 Reshuffle Coup 1962 First Election/Selection 1967 Regular Election/Selectio 1972 Regular Election/Selectio 1977 Regular Election/Selectio 1979 Regular Election/Selection 1980 Reshuffle Coup

1982 Forced Election/Selection 1984 First Election/Selection 1963 Forced Election/Selection 1966 Regular Election/Selection 1967 Regur Election/Seloction 1979 Regular Election/Selection 1990 Successful Rebellion 1990 Successful Rebellion 1955 Regular Election/Selection 1955 Forced Election/Selection 1956 Forced Election/Selection 1960 Regular Election/Selectio 1981 Regime-Change Coup 1982 Forced Election/Selection 1983 Forced Election/Selection 1990 First Election/Selection 1951 Regular Election/Selection 1953 Regular Election/Selection 1957 Reshuffle Coup 1958 Forced Election/Selection 1958 Forced Election/Selection First Election/Selection

1985 First Election/Selection 1992 Regular Election/Selection 1980 First Election/Selection 1988 Regime-Change Coup 1991 Reshuffle Coup 1966 Regime-Change Coup 1966 Reshuffle Coup 1968 First Election/Selection 1976 Regime-Change Coup 1976 Regime-Change 1950 First Election/Selection 1950 First Election/Selection 1956 Regular Election/Selection 1963 Regime-Change Coup
1963 Reshuffle Coup 1963 Reshuffle Coup 1975 Regime-Change Co
1980 Reshuffle Coup 2001 First Election/Selection
Regime-Change Coup Regular Voluntary Resignation Irregula Voluntary Resignation Irregular $\begin{array}{ll}\text { Reshuffle Coup Irregular } \\ \text { Reshuffle Coup } & \text { Irregular }\end{array}$ Reshuffle Coup Irregular Voluntary Resignation Irregular Voluntary Resignation Regular Reshuffle Coup Regular Reshuffle Coup Irregular Voluntary Resignation Irregular Voluntary Resignation Regular Voluntary Resignation Regular Voluntary Resignation Regular Voluntary Resignation Regular Reshuffle Coup Regular Legal Removal Irregular Voluntary Resignation Irregular Voluntary Resignation Regular Voluntary Resignation Regular Natural Death Voluntary Resignation Regur $\begin{array}{ll}\text { Voluntary Resignation } & \text { Regular } \\ \text { Rebellion } & \text { Regular }\end{array}$ $\begin{array}{ll}\text { Veluntary Resignation } & \text { Regular } \\ \text { Irregular }\end{array}$ Voluntary Resignation Regular Assassination Regular $\begin{array}{ll}\text { Assassination } & \text { Regular } \\ \text { Legal Removal } & \text { Regular }\end{array}$ Voluntary Resignation Regular $\begin{array}{ll}\text { Voluntary Resignation } & \text { Regular } \\ \text { Voluntary Resignation } & \text { Regular }\end{array}$ $\begin{array}{ll}\text { Voluntary Resignation } & \text { Regular } \\ \text { Natural Death } & \text { Irregula }\end{array}$ $\begin{array}{ll}\text { Natural Death } & \text { Irregular } \\ \text { Legal Removal } & \text { Irregular }\end{array}$ Legal Removal Irregular Voluntary Resignation Irregular Foreign Overthrow Irregular Resignation, Health Regular Voluntary Resignation Regular Protest Voluntary Resignation Irregular Protest Irregular Natural Death Vogular Regime-Change Coup Voluntary Resignation Regular Voluntary Resignation Regur Veshuffle Coup Irregular - Irregular $\begin{array}{ll}\text { Roluntary Resignation } & \text { Regular } \\ \text { Reshuffle Coup } & \text { Irregular }\end{array}$ Voluntary Resignation Irregular Voluntary Resignation Irregular Voluntary Resignation Regular $\begin{array}{ll}\text { Voluntary Resignation } & \text { Regular } \\ \text { Reshuffle Coup } & \text { Irregular }\end{array}$ $\begin{array}{ll} & \text { Reshuffle Coup } \\ \text { Voluntary Resignation } & \text { Irregular }\end{array}$ Voluntary Resignation Irregular Reshuffle Coup Irregular $\begin{array}{ll}\text { Voluntary Resignation } & \text { Irregular } \\ \text { Voluntary Resignation } & \text { Regular }\end{array}$
Military Coup

Regular

Removed by Military Power Struggle Removed by Military Power Struggle Regular

Regular

Military Coup

Military Coup

Regular

Regular

Regular

Regular

Regular

Military Coup

Removed by Military Power Struggle

Regular

Regular

Regular
Natural Deat

Regular

Rebellion

Rebellion

Regular

Assassination by Unsupported Individual Regula

Regular

Regular
Natural Death

Removed by Military Power Struggle

Regular

Foreign

Regular

Regular

Removed by Military Power Struggle

Protest

Still in Office

Natural Death

Regular

Military Coup

Regular

Regula

Protest

Regular

Megular

Regular

Regula

Regular
Military Coup

Regular

Military Coup

Regular

Regular 


$\begin{array}{rrrl}140001 & 140 & 4 & 1964 \text { Castello Branco } \\ 140002 & 140 & 3 & 1967 \text { Costa de Silva } \\ 140003 & 140 & 9 & 1969 \text { Military Junta } \\ 140004 & 140 & 10 & 1969 \text { Medici } \\ 140005 & 140 & 3 & 1974 \text { Geisel } \\ 140006 & 140 & 3 & 1979 \text { Figueiredo } \\ 145001 & 145 & 5 & 1951 \text { Ballivian Rojas } \\ 145002 & 145 & 4 & 1952 \text { Paz Estenssoro } \\ 145003 & 145 & 6 & 1956 \text { Siles Zuazo } \\ 145004 & 145 & 8 & 1960 \text { Paz Estenssoro } \\ 145005 & 145 & 11 & 1964 \text { Barrientos Ortuna } \\ 145006 & 145 & 1 & 1966 \text { Ovando Candia } \\ 145007 & 145 & 8 & 1966 \text { Barrientos Ortuna } \\ 145008 & 145 & 4 & 1969 \text { Siles Salinas } \\ 145009 & 145 & 9 & 1969 \text { Ovando Candia } \\ 145010 & 145 & 10 & 1970 \text { Torres } \\ 145011 & 145 & 8 & 1971 \text { Banzer Suarez } \\ 145012 & 145 & 7 & 1978 \text { Pereda Asbun } \\ 145013 & 145 & 11 & 1978 \text { Padilla Aranciba } \\ 145014 & 145 & 8 & 1979 \text { Guevara Arze } \\ 145015 & 145 & 11 & 1979 \text { Natusch Busch } \\ 145016 & 145 & 11 & 1979 \text { Gueiler Tejada } \\ 145017 & 145 & 7 & 1980 \text { Garcia Meza Tejada } \\ 145018 & 145 & 8 & 1981 \text { Torrelio Villa } \\ 145019 & 145 & 7 & 1982 \text { Vildoso Calderon } \\ 150001 & 150 & 5 & 1954 \text { Pareira } \\ 150002 & 150 & 7 & 1954 \text { Stroessner } \\ 150003 & 150 & 2 & 1989 \text { Rodriguez Pedotti } \\ 155001 & 155 & 9 & 1973 \text { Pinochet } \\ 160001 & 160 & 9 & 1955 \text { Lonardi } \\ 160002 & 160 & 11 & 1955 \text { Aramburu } \\ 160003 & 160 & 5 & 1958 \text { Frondizi } \\ 160004 & 160 & 3 & 1962 \text { Guido } \\ 160005 & 160 & 10 & 1963 \text { Arturo Illia } \\ 160006 & 160 & 6 & 1966 \text { Ongania } \\ 160007 & 160 & 6 & 1970 \text { Lanusse } \\ 160008 & 160 & 6 & 1970 \text { Levingston } \\ 160009 & 160 & 3 & 1971 \text { Lanusse } \\ 160010 & 160 & 3 & 1976 \text { Videla } \\ 160011 & 160 & 3 & 1981 \text { Viola } \\ 160012 & 160 & 11 & 1981 \text { Liendo } \\ 160013 & 160 & 12 & 1981 \text { Galtieri } \\ 160014 & 160 & 6 & 1982 \text { Saint-Jean } \\ 160015 & 160 & 7 & 1982 \text { Bignone } \\ 165001 & 165 & 6 & 1976 \text { Demichelli } \\ 165002 & 165 & 9 & 1976 \text { Mendez Manfredini } \\ 165003 & 165 & 9 & 1981 \text { Alvarez Armalino } \\ 221001 & 221 & 4 & 2005 \text { Albert } \\ 223001 & 223 & 11 & 1989 \text { Hans-Adam II } \\ 230001 & 230 & 11 & 1975 \text { Juan Carlos } \\ 230002 & 230 & 11 & 1975 \text { Arias Navarro } \\ 235001 & 235 & 9 & 1968 \text { Caetano } \\ 235002 & 235 & 4 & 1974 \text { Spinola } \\ 235003 & 235 & 9 & 1974 \text { Costa Gomes } \\ 265001 & 265 & 7 & 1950 \text { Ulbricht } \\ & & & \end{array}$

\begin{tabular}{|c|c|c|c|}
\hline 1967 Regime-Change Coup & Voluntary Resignation & Irregular & Regular \\
\hline 1969 First Election/Selection & Reshuffle Coup & Regular & Retired Due to III Health \\
\hline 1969 Reshuffle Coup & Voluntary Resignation & Irregular & Regular \\
\hline 1974 First Election/Selection & Voluntary Resignation & Irregular & Regular \\
\hline 1979 Regular Election/Selection & Voluntary Resignation & Regular & Regular \\
\hline 1985 Regular Election/Selection & Voluntary Resignation & Regular & Regular \\
\hline 1952 Reshuffle Coup & Regime-Change Coup & Irregular & Rebellion \\
\hline 1956 Regime-Change Coup & Voluntary Resignation & Regular & Regular \\
\hline 1960 First Election/Selection & Voluntary Resignation & Regular & Regular \\
\hline 1964 Regular Election/Selection & Reshuffle Coup & Regular & Military Coup \\
\hline 1966 Reshuffle Coup & Voluntary Resignation & Irregular & Regular \\
\hline 1966 Regular Election/Selection & Voluntary Resignation & Irregular & Regular \\
\hline 1969 Regular Election/Selection & Natural Death & Regular & Natural Death \\
\hline 1969 Regular Election/Selection & Reshuffle Coup & Regular & Military Coup \\
\hline 1970 Reshuffle Coup & Reshuffle Coup & Irregular & Military Coup \\
\hline 1971 Reshuffle Coup & Reshuffle Coup & Irregular & Military Coup \\
\hline 1978 Reshuffle Coup & Reshuffle Coup & Irregular & Military Coup \\
\hline 1978 Reshuffle Coup & Reshuffle Coup & Irregular & Military Coup \\
\hline 1979 Reshuffle Coup & Voluntary Resignation & Irregular & Regular \\
\hline 1979 Regular Election/Selection & Regime-Change Coup & Regular & Military Coup \\
\hline 1979 Regime-Change Coup & Protest & Irregular & Regular \\
\hline 1980 Forced Election/Selection & Regime-Change Coup & Regular & Removed by Other Government Actors \\
\hline 1981 Regime-Change Coup & Reshuffle Coup & Irregular & Military Coup \\
\hline 1982 Reshuffle Coup & Legal Removal & Irregular & Removed by Military Power Struggle \\
\hline 1982 First Election/Selection & Voluntary Resignation & Irregular & Regular \\
\hline 1954 Regime-Change Coup & Voluntary Resignation & Regular & Regular \\
\hline 1989 First Election/Selection & Voluntary Resignation & Irregular & Military Coup \\
\hline 1993 Regime-Change Coup & Voluntary Resignation & Irregular & Regular \\
\hline 1990 Regime-Change Coup & Voluntary Resignation & Irregular & Regular \\
\hline 1955 Regime-Change Coup & Reshuffle Coup & Irregular & Military Coup \\
\hline 1958 Reshuffle Coup & Voluntary Resignation & Irregular & Regular \\
\hline 1962 First Election/Selection & Reshuffle Coup & Regular & Military Coup \\
\hline 1963 Reshuffle Coup & Voluntary Resignation & Regular & Regular \\
\hline 1966 First Election/Selection & Reshuffle Coup & Regular & Military Coup \\
\hline 1970 Reshuffle Coup & Reshuffle Coup & Irregular & Military Coup \\
\hline 1970 Reshuffle Coup & Voluntary Resignation & Irregular & Regular \\
\hline 1971 First Election/Selection & Reshuffle Coup & Regular & Military Coup \\
\hline 1973 Reshuffle Coup & Voluntary Resignation & Irregular & Regular \\
\hline 1981 Regime-Change Coup & Voluntary Resignation & Irregular & Regular \\
\hline 1981 First Election/Selection & Resignation, Health & Regular & Retired Due to III Health \\
\hline 1981 Regular Election/Selection & Legal Removal & Regular & Military Coup \\
\hline 1982 Forced Election/Selection & Legal Removal & Irregular & Military Coup \\
\hline 1982 Forced Election/Selection & Voluntary Resignation & Irregular & Regular \\
\hline 1983 Regular Election/Selection & Voluntary Resignation & Regular & Regular \\
\hline 1976 Reshuffle Coup & Voluntary Resignation & Irregular & Military Coup \\
\hline 1981 First Election/Selection & Voluntary Resignation & Irregular & Regular \\
\hline 1985 Regular Election/Selection & Voluntary Resignation & Irregular & Regular \\
\hline Regular Election/Selection & Still in Power & NA & NA \\
\hline Regular Election/Selection & Still in Power & NA & NA \\
\hline 1975 First Election/Selection & Voluntary Resignation & Regular & Regular \\
\hline 1976 Regular Election/Selection & Legal Removal & Regular & Regular \\
\hline 1974 First Election/Selection & Regime-Change Coup & Regular & Military Coup \\
\hline 1974 Regime-Change Coup & Voluntary Resignation & Irregular & Regular \\
\hline 1976 First Election/Selection & Voluntary Resignation & Regular & Regular \\
\hline 1971 First Election/Selection & Voluntary Resignation & Regular & Regular \\
\hline
\end{tabular}




$\begin{array}{llrl}265002 & 265 & 5 & 1971 \text { Honecker } \\ 265003 & 265 & 10 & 1989 \text { Krenz } \\ 265004 & 265 & 12 & 1989 \text { Gysi } \\ 290001 & 290 & 3 & 1956 \text { Ochab } \\ 290002 & 290 & 10 & 1956 \text { Gomulka } \\ 290003 & 290 & 12 & 1970 \text { Gierek } \\ 290004 & 290 & 9 & 1980 \text { Kania } \\ 290005 & 290 & 10 & 1981 \text { Jaruzelski } \\ 305001 & 305 & 4 & 1953 \text { Raab } \\ 310001 & 310 & 7 & 1956 \text { Gero } \\ 310002 & 310 & 10 & 1956 \text { Nagy } \\ 310003 & 310 & 11 & 1956 \text { Kadar } \\ 310004 & 310 & 5 & 1988 \text { Grosz } \\ 310005 & 310 & 10 & 1989 \text { Szuros } \\ 315001 & 315 & 3 & 1953 \text { Zapotocky } \\ 315002 & 315 & 11 & 1957 \text { Novotny } \\ 315003 & 315 & 1 & 1968 \text { Dubcek } \\ 315004 & 315 & 8 & 1968 \text { Svoboda } \\ 315005 & 315 & 8 & 1968 \text { Husak } \\ 339001 & 339 & 4 & 1985 \text { Alia } \\ 344001 & 344 & 5 & 1991 \text { Tudjman } \\ 344002 & 344 & 11 & 1999 \text { Pavletic } \\ 344003 & 344 & 2 & 2000 \text { Tomcic } \\ 344004 & 344 & 2 & 2000 \text { Mesic } \\ 345001 & 345 & 5 & 1980 \text { Kolisevski } \\ 345002 & 345 & 5 & 1980 \text { Mijatovic } \\ 345003 & 345 & 5 & 1981 \text { Kraigher } \\ 345004 & 345 & 5 & 1982 \text { Stambolic } \\ 345005 & 345 & 5 & 1983 \text { Spiljac } \\ 345006 & 345 & 5 & 1984 \text { Djuranovic } \\ 345007 & 345 & 5 & 1985 \text { Vlajkovic } \\ 345008 & 345 & 5 & 1986 \text { Hasani } \\ 345009 & 345 & 5 & 1987 \text { Mojsov } \\ 345010 & 345 & 5 & 1988 \text { Dizarevic } \\ 345011 & 345 & 5 & 1989 \text { Milosevic } \\ 346001 & 346 & 12 & 1990 \text { Izetbegovic } \\ 346002 & 346 & 10 & 1998 \text { Radisic } \\ 346003 & 346 & 6 & 1999 \text { Jelavic } \\ 346004 & 346 & 2 & 2000 \text { Izetbegovic } \\ 346005 & 346 & 10 & 2000 \text { Radisic } \\ 346006 & 346 & 6 & 2001 \text { Krizanovic } \\ 346007 & 346 & 2 & 2002 \text { Belkic } \\ 346008 & 346 & 10 & 2002 \text { Sarovic } \\ 346009 & 346 & 4 & 2003 \text { Borislav Paravac } \\ 346010 & 346 & 6 & 2003 \text { Dragan Covic } \\ 346011 & 346 & 2 & 2004 \text { Sulejman Tihic } \\ 346012 & 346 & 10 & 2004 \text { Borislav Paravac } \\ 346013 & 346 & 6 & 2005 \text { Miro Jovic } \\ 346014 & 346 & 2 & 2006 \text { Sulejman Tihic } \\ 346015 & 346 & 11 & 2006 \text { Radmanovic } \\ 346016 & 346 & 7 & 2007 \text { Zeljko Komsic } \\ 346017 & 346 & 3 & 2008 \text { Silajdzic } \\ 346018 & 346 & 11 & 2008 \text { Radmanovic } \\ 346019 & 346 & 7 & 2009 \text { Zeljko Komsic } \\ 346020 & 346 & 3 & 2010 \text { Silajdzic } \\ & & & \end{array}$

1989 Regular Election/Selection 1989 Regular Election/Selection 1990 Regular Election/Selection 1956 First Election/Selection 1970 Regular Election/Selection 1980 Regular Election/Selection 1981 Regular Election/Selection 1990 Regular Election/Selection 1961 Regular Election/Selectio 1956 Forced Election/Selection 1956 Forced Election/Selection 1988 Foreign Installation 1989 First Election/Selection 1990 Regular Election/Selection 1968 Regular Election/Selection 1968 Regular Election/Selection 1968 Forced Election/Selection 1989 Regular Election/Selection 1992 First Election/Stsection 1999 First Election/Selection 2000 Regular Election/Selection 2000 Regular Election/selection . 2000 Regular Election/Selection

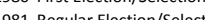
1981 Regular Election/Selection (982 Regular Election/Selection 1983 Regular Election/Selection 1984 Regular Election/Selection 1985 Regular Election/Selection 1986 Regular Election/Selection 1987 Regular Election/Selection 1988 Regular Election/Selection 1989 Regular Election/Selectio 1998 First Election/Selection 1999 Regular Election/Selection 2000 Regular Election/Selection 2000 Regular Election/Selectio 2001 Regular Election/Selection 2002 Regular Election/Selection 2002 Regular Election/Selection 2003 Regular Election/Selection 2003 Regular Election/Selection 2004 Regular Election/Selection 2004 Regular Election/Selection 2006 Resular Election/Selection 2006 Regar Election/Selection 2006 Regular Election/Selection 2007 Regular Election/Selection 2008 Regular Election/Selection 2008 Regular Election/Selection 2009 Regular Election/Selection

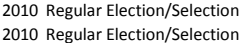

Voluntary Resignation Regular Voluntary Resignation Regular Voluntary Resignation Regular Voluntary Resignation Regular Protest Regular

Protest Vegular Voluntary Resignation Regular Voluntary Resignation Regular Foreign Overthrow Irregular Foreign Overthrow Irregular Voluntary Resignation Foreign Voluntary Resignation Regular Voluntary Resignation Regular Voluntary Resignation Regular Voluntary Resignation Regular Foreign Overthrow Regular Voluntary Resignation Regular Voluntary Resignation Foreign Voluntary Resignation Regular Natural Death Voluntary Resignation Regular Voluntary Resignation Regular Voluntary Resignation Regular Voluntay Resiznation Regur Voluntary Resignation Regular Voluntary Resignation Regular Voluntary Resignation Regular Voluntary Resignation Regular Voluntary Resignation Regular Voluntary Resignation Regular Voluntary Resignation Regular Voluntary Resignation Regular Voluntary Resignation Regular Voluntary Resignation Regular Protest

oluntary Resignation Voluntary Resignation Regular Voluntary Resignation Regular Voluntary Resignation Regular Voluntary Resignation Regular Voluntary Resignation Regular Voluntary Resignation Regular Voluntary Resignation Regular Voluntary Resignation Regular Voluntary Resignation Regular Voluntary Resignation Regular Voluntary Resignation Regular Oluntary Resignation Regular Voluntary Resignation Regular Voluntary Resignation Regular voluntary Resignation Regular oluntary Resignation Regular Voluntary Resignation Regular Voluntary Resignation Regular Voluntary Resignation Regular
Regular

Regular

Foreign
Regular

Protest

Natural Deat

Regular

Regular

Regular

Protest

Foreign

Regular

Regular

Natural Death

Regular

Foreign

Foreign

Foreign
Regular

Regular

Natural Death

Regular

Regular

Regular

Regular

Regular

Regular

Regular

Regular

Regular

Regular

Regular

Regular

Regular

Regular

Regular

Regular

Regular

Regular

Retired Due to III Health

Regular

Regular

Regular

Regular

Regular

Regular

Regular

Regular

Regular

Regular

Regular

Regular

Regular

Regular

Regular

Regular 


$\begin{array}{llrl}346021 & 346 & 11 & 2010 \text { Radmanovic } \\ 346022 & 346 & 7 & 2011 \text { Zeljko Komsic } \\ 346023 & 346 & 3 & 2012 \text { lzetbegovic } \\ 346024 & 346 & 11 & 2012 \text { Radmanovic } \\ 346025 & 346 & 7 & 2013 \text { Komsic } \\ 346026 & 346 & 3 & 2014 \text { Izetbegovic } \\ 346027 & 346 & 11 & 2014 \text { Ivanic } \\ 346028 & 346 & 7 & 2015 \text { Covic } \\ 346029 & 346 & 3 & 2016 \text { lzetbegovic } \\ 347001 & 347 & 2 & 2008 \text { Thaci } \\ 350001 & 350 & 4 & 1967 \text { Kollias } \\ 350002 & 350 & 12 & 1967 \text { Papadopoulos } \\ 350003 & 350 & 11 & 1973 \text { lonannides } \\ 352001 & 352 & 8 & 1960 \text { Makarios } \\ 352002 & 352 & 7 & 1974 \text { Sampson } \\ 352003 & 352 & 7 & 1974 \text { Clerides } \\ 352004 & 352 & 12 & 1974 \text { Makarios } \\ 352005 & 352 & 8 & 1977 \text { Kyprianou } \\ 352006 & 352 & 2 & 1988 \text { Vassiliou } \\ 352007 & 352 & 2 & 1993 \text { Clerides } \\ 352008 & 352 & 2 & 2003 \text { Tassos Nikolaou Papadopoulos } \\ 352009 & 352 & 2 & 2008 \text { Dimitris Christofias } \\ 352010 & 352 & 2 & 2013 \text { Nikos Anastasiadis } \\ 355001 & 355 & 2 & 1950 \text { Chervenkov } \\ 355002 & 355 & 4 & 1956 \text { Zhivkov } \\ 355003 & 355 & 11 & 1989 \text { Mladenov } \\ 355004 & 355 & 7 & 1990 \text { Lukanov } \\ 360001 & 360 & 3 & 1965 \text { Ceausescu } \\ 360002 & 360 & 12 & 1989 \text { Roman } \\ 365001 & 365 & 3 & 1953 \text { Malenkov } \\ 365002 & 365 & 3 & 1953 \text { Khrushchev } \\ 365003 & 365 & 10 & 1964 \text { Brezhnev } \\ 365004 & 365 & 11 & 1982 \text { Andropov } \\ 365005 & 365 & 2 & 1984 \text { Chernenko } \\ 365006 & 365 & 3 & 1985 \text { Gorbachev } \\ 365007 & 365 & 1 & 2000 \text { Putin } \\ 370001 & 370 & 9 & 1991 \text { Shushkevich } \\ 370002 & 370 & 1 & 1994 \text { Hryb } \\ 370003 & 370 & 7 & 1994 \text { Lukashenko } \\ 371001 & 371 & 10 & 1991 \text { Ter-Petrosyan } \\ 372001 & 372 & 4 & 1991 \text { Gamsakhurdia } \\ 372002 & 372 & 1 & 1992 \text { loseliani } \\ 372003 & 372 & 3 & 1992 \text { Shevardnadze } \\ 372004 & 372 & 11 & 2003 \text { Burdjanadze } \\ 373001 & 373 & 9 & 1991 \text { Mutalibov } \\ 373002 & 373 & 3 & 1992 \text { Mamedov } \\ 373003 & 373 & 6 & 1993 \text { H. Aliyev } \\ 373004 & 373 & 8 & 2003 \text { llhma Aliyev } \\ 402001 & 402 & 7 & 1975 \text { Pires } \\ 403001 & 403 & 6 & 1975 \text { da Costa } \\ 404001 & 404 & 9 & 1974 \text { Cabral } \\ 404002 & 404 & 11 & 1980 \text { Vieira } \\ 404003 & 404 & 5 & 1999 \text { Mane } \\ 404004 & 404 & 5 & 1999 \text { Sanha } \\ 404005 & 404 & 9 & 2003 \text { Henrique Pereira Rosa } \\ & & & \end{array}$

2011 Regular Election/Selection 2012 Regular Election/Selection 2012 Regular Election/Selection Regular Election/Selection 2014 Regular Election/Selection 2014 Regular Election/Selection 2015 Regular Election/Selection 016 Regular Election/Selection Regular Election/Selection 2014 First Election/Selection 1967 Regime-Change Coup 1973 First Election/Selection 1974 Reshuffle Coup 1974 First Election/Selection 1974 Foreign Installation

1974 Forced Election/Selection 1977 Regular Election/Selection 1988 Regular Election/Selection 1993 Regular Election/Selection 2003 Regular Election/Selection 2008 Regular Election/Selection 2013 Regular Election/Selection Regular Election/Selection 1956 Regular Election/Selection 1989 Regular Election/Selection 1990 Regular Election/Selection 990 Forced Election/Selection 1989 First Election/Selectio

1991 Successful Protest 1953 Regular Election/Selection 1964 Regular Election/Selection 1982 Regular Election/Selection 1984 Regular Election/Selection 1985 Regular Election/Selection 1991 Regular Election/Selection Regular Election/Selection 1994 First Election/Selection 1994 Regular Election/Selection Regular Election/Selectio 1998 First Election/Selection 1992 First Election/Selection 2003 First Election/Section 2004 Forced Election/seten (992 First Eloction/sect 992 Forced Election/Selection 2003 Forced Election/Selection First Election/Selection 1991 First Election/Selection 1991 First Election/Selection 1980 Successful Rebellion 1999 Reshuffle Coup 1999 Regime-Change Coup 2000 First Election/Selection
Voluntary Resignation Regular Voluntary Resignation NA Voluntary Resignation NA Voluntary Resignation NA Voluntary Resignation Regular Voluntary Resignation Regular Voluntary Resignation Regular Voluntary Resignation Regular Still in Power NA Voluntary Resignation Regular Voluntary Resignation Irregular Reshuffle Coup Irregular Voluntary Resignation Irregular Foreign Overthrow Regular Voluntary Resignation Irregular Voluntary Resignation Regular Natural Death Regular Voluntary Resignation Regular Voluntary Resignation Regular Voluntary Resignation Regular Voluntary Resignation Regular Voluntary Resignation Regular Still in Power $\quad$ Regular Voluntary Resignation Regular Voluntary Resignation Regular Voluntary Resignation Regular
Protest Protest $\begin{array}{ll}\text { Regular } \\ \text { Voluntary Resignation Regular }\end{array}$ $\begin{array}{lll}\text { Voluntary Resignation } & \begin{array}{l}\text { Regular } \\ \text { Protest }\end{array} & \text { Irregular }\end{array}$ Protes

Protest Regular Voluntary Resignation Regular Voluntary Resignation Regular Natural Death Regular Natural Death Regular Natural Death Regular Regime-Change Coup Regula Still in Power Regula Voluntary Resignation Regular Voluntary Resignation Still in Power

Voluntary Resignation Regular Vollion Resignation Voluntary Resignation Regular Protest Voluntary Resignation Regular Protest Resignation Regular Protest Resiton Stillin Pow, Health Regular Stil in Power Regular Voluntry Resignation Voluntary Resignation NA Reshuffle Coup Irregular Regime-Change Coup Irregula $\begin{array}{ll}\text { Voluntary Resignation } & \text { Irregular } \\ \text { Voluntary Resignation } & \text { Regular }\end{array}$
Regula

$N$

Regular

Regula

Regular
Still in Office

NA

Regular

Military Coup

Military Coup

Regular

Military Coup

Regular

Natural Death

Regular

Regular

Regular

Regular

Still in Office

Regular

Regular

Regular

Regular

Protest

Regular

Regular

Regular

Natural Death

Natural Death

Natural Death

Military Coup

Still in Office

Regular

Still in Office

Regular

Rebellion

Regular

Protest

Regula

Regular

Regular

Retired Due to III Health

Still in Office

Regular

Military Coup

Military Coup

Regular

Regular
Regular 


\begin{tabular}{|c|c|c|c|}
\hline 404006 & 404 & 3 & 2009 Raimundo Perreira \\
\hline 404007 & 404 & 9 & 2009 Sanha \\
\hline 404008 & 404 & 1 & 2012 Pereira \\
\hline 404009 & 404 & 4 & 2012 Kuruma \\
\hline 404010 & 404 & 5 & 2012 Nhamadjo \\
\hline 411001 & 411 & 8 & 1979 Nguema Mbasogo \\
\hline 420001 & 420 & 2 & 1965 Jawara \\
\hline 420002 & 420 & 7 & 1994 Jammeh \\
\hline 432001 & 432 & 9 & 1960 Keita \\
\hline 432002 & 432 & 11 & 1968 Traore \\
\hline 432003 & 432 & 3 & 1991 Amadou Toure \\
\hline 432004 & 432 & 3 & 2012 Sanogo \\
\hline 432005 & 432 & 4 & 2012 Traore \\
\hline 433001 & 433 & 8 & 1960 Senghor \\
\hline 433002 & 433 & 1 & 1981 Diouf \\
\hline 434001 & 434 & 1 & 1960 Maga \\
\hline 434002 & 434 & 10 & 1963 Soglo \\
\hline 434003 & 434 & 1 & 1964 Apithy \\
\hline 434004 & 434 & 11 & 1965 Congacou \\
\hline 434005 & 434 & 12 & 1965 Soglo \\
\hline 434006 & 434 & 12 & 1967 Alley \\
\hline 434007 & 434 & 8 & 1968 Zinsou \\
\hline 434008 & 434 & 12 & 1969 Paul-Emile de Souza \\
\hline 434009 & 434 & 5 & 1970 Maga \\
\hline 434010 & 434 & 4 & 1972 Ahomadegbe \\
\hline 434011 & 434 & 10 & 1972 Kerekou \\
\hline 435001 & 435 & 11 & 1960 Ould Daddah \\
\hline 435002 & 435 & 7 & 1978 Ould Mohamed Salek \\
\hline 435003 & 435 & 4 & 1979 Ould Bouceif \\
\hline 435004 & 435 & 6 & 1979 Ould Ahmed Louly \\
\hline 435005 & 435 & 1 & 1980 Ould Haidalla \\
\hline 435006 & 435 & 12 & 1984 Sidi Ahmed Taya \\
\hline 435007 & 435 & 8 & 2005 Ould Mohamed Vall \\
\hline 435008 & 435 & 8 & 2008 Ould Abdel Aziz \\
\hline 435009 & 435 & 4 & 2009 dit M'Bare \\
\hline 435010 & 435 & 8 & 2009 Ould Abdel Aziz \\
\hline 436001 & 436 & 10 & 1960 Diori \\
\hline 436002 & 436 & 4 & 1974 Kountche \\
\hline 436003 & 436 & 11 & 1987 Seibou \\
\hline 436004 & 436 & 1 & 1996 Mainassara \\
\hline 436005 & 436 & 4 & 1999 Wanke \\
\hline 436006 & 436 & 2 & 2010 Djibo \\
\hline 437001 & 437 & 8 & 1960 Houphouet-Boigny \\
\hline 437002 & 437 & 12 & 1993 Konan Bedie \\
\hline 437003 & 437 & 12 & 1999 Guei \\
\hline 437004 & 437 & 10 & 2000 Laurent Gbagbo \\
\hline 438001 & 438 & 10 & 1958 Toure \\
\hline 438002 & 438 & 3 & 1984 Beavogui \\
\hline 438003 & 438 & 4 & 1984 Conte \\
\hline 438004 & 438 & 12 & 2008 Dadis Camara \\
\hline 438005 & 438 & 12 & 2009 Sekouba Konate \\
\hline 439001 & 439 & 8 & 1960 Yameogo \\
\hline 439002 & 439 & 1 & 1966 Lamizana \\
\hline 439003 & 439 & 11 & 1980 Zerbo \\
\hline 439004 & 439 & 11 & 1982 J. P. Ouedraogo \\
\hline
\end{tabular}

2009 Regular Election/Selection 2012 Regular Election/Selection 2012 Regular Election/Selection 2012 Reshuffle Coup

2014 First Election/Selection Reshuffle Cou

994 First Election/Selectio Regime-Change Coup

1968 First Election/Selectio

1991 Regime-Change Coup

1992 Regime-Change Coup

2012 Regime-Change Coup

2013 First Election/Selection

1980 First Election/Selection

2000 Regular Election/Selection

1963 First Election/Selection

1964 Regime-Change Coup

1965 Reshuffle Coup

1965 Reshuffle Coup

1968 Regime-Change Coup

1969 First Election/Selection

1970 Reshuffle Coup

1972 Forced Election/Selection

1972 First Election/Selection

991 Regime-Change Coup

978 First Election/Selection

1979 Regime-Change Coup

1979 First Election/Selection

1980 Regular Election/Selection

1984 Reshuffle Coup

2005 Reshuffle Coup

2007 Regime-Change Coup

2009 Regime-Change Coup

009 First Election/Selection

Regular Election/Selection

1974 First Election/Selection

1987 Regime-Change Coup

1993 First Election/Selection

1999 Regime-Change Coup

1999 Regime-Change Coup

2011 Regime-Change Coup

1993 First Election/Selection

1999 First Election/Selectio

2000 Regime-Change Coup

2011 Forced Election/Selection

1984 First Election/Selection

1984 First Election/Selection

2008 Regime-Change Coup

009 Regime-Change Coup

2010 Forced Election/Selection

1966 First Election/Selectio

1980 Regime-Change Coup

1982 Regime-Change Coup
Voluntary Resignation Regular tural Death Regula $\begin{array}{ll}\text { Natural Death } & \text { Regular } \\ \text { Reshuffle Coup } & \text { Regular }\end{array}$ $\begin{array}{ll}\text { Reshuffle Coup } & \text { Regular } \\ \text { Voluntary Resignation } & \text { Irregular }\end{array}$ $\begin{array}{ll}\text { Voluntary Resignation } & \text { Irregular } \\ \text { Voluntary Resignation } & \text { Regular }\end{array}$ $\begin{array}{ll}\text { Voluntary Resignation } & \text { Regular } \\ \text { Still in Power } & \text { Regular }\end{array}$

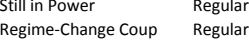
$\begin{array}{ll} & \text { Regular } \\ \text { Regime-Change Coup } & \text { Irregula }\end{array}$ Still in Power Irregular 作 Iregular Iregular Voluntary Resignation Irregular Voluntary Resignation Regular Voluntary Resignation Regular Regime-Change Coup Regular Voluntary Resignation Irregular Reshuffle Coup Irregular Reshuffle Coup Irregular Regime-Change Coup Irregular Legal Removal Irregular Reshuffle Coup Irregular Voluntary Resignation Irregular Voluntary Resignation Regular Regime-Change Coup Irregular Voluntary Resignation Irregular Regime-Change Coup Regular Legal Removal Irregular Natural Death Irregular Reshuffle Coup Regular Reshuffle Coup Irregula Regime-Change Coup Irregular oluntary Resignation Irregular Voluntary Resignation Irregular Voluntary Resignation Regular Still in Power Regular Regime-Change Coup Regular Natural Death Irregular Voluntary Resignation Regular Regime-Change Coup Irregular Voluntary Resignation Irregular Voluntary Resignation Irregular Natural Death Regular Regime-Change Coup Regular $\begin{array}{ll}\text { Protest } & \text { Regular } \\ \text { Irregular }\end{array}$ Rest

Irregular Regular $\begin{array}{ll}\text { Regime-Change Coup } & \text { Irregular } \\ \text { Natural Death } & \text { Irregular }\end{array}$ $\begin{array}{ll}\text { Natural Death } & \text { Irregular } \\ \text { Resignation, Health } & \text { Irregular }\end{array}$ $\begin{array}{ll}\text { Resignation, Health } & \text { Irregular } \\ \text { Voluntary Resignation } & \text { Irregular }\end{array}$ $\begin{array}{ll}\text { Voluntary Resignation } & \text { Irregular } \\ \text { Regime-Change Coup } & \text { Regular }\end{array}$ $\begin{array}{ll}\text { Regime-Change Coup } & \text { Regular } \\ \text { Regime-Change Coup } & \text { Irregular }\end{array}$ Regime-Change Coup Irregular
Regime-Change Coup $\begin{array}{ll}\text { Regime-Change Coup } & \text { Irregular } \\ \text { Reshuffle Coup } & \text { Irregular }\end{array}$
Regula

Natural Death

Military Coup

Regular

Regular
Still in Office

Military Coup

Still in Office

Military Coup

Military Coup

Regular

Regular

Regular

Regular

Regular

Military Coup

Regular

Military Coup

Military Coup

Military Coup

Regular

Military Coup

Metrary coup

Regular

Megular

Regular

Military Coup

Removed by Military Power Strugg

Natural Death

Removed by Military Power Struggle

Military Coup

Military Coup

Regular

Regular

Regular

Still in Office

Military Coup

Natural Death

Regular

Military Coup

Regula

Natural Death

Military Coup

Protest

Military Coup

Military Coup

Natural Death

Miltary Coup

Natural Death

Military Coup

Regular

Military Coup

Military Coup

Military Coup

Military Coup 


\begin{tabular}{llrl}
439005 & 439 & 8 & 1983 Sankara \\
439006 & 439 & 10 & 1987 Campaore \\
439007 & 439 & 11 & 2014 Zida \\
439008 & 439 & 11 & 2014 Kafando \\
450001 & 450 & 7 & 1971 Tolbert \\
450002 & 450 & 4 & 1980 Doe \\
450003 & 450 & 11 & 1990 Sawyer \\
450004 & 450 & 3 & 1994 Kpormapkor \\
450005 & 450 & 9 & 1995 Sankawulo \\
450006 & 450 & 9 & 1996 Perry \\
450007 & 450 & 8 & 1997 Taylor \\
450008 & 450 & 8 & 2003 Moses Zeh Blah \\
450009 & 450 & 10 & 2003 Bryant \\
451001 & 451 & 3 & 1967 Juxon-Smith \\
451002 & 451 & 4 & 1968 Stevens \\
451003 & 451 & 11 & 1985 Momoh \\
451004 & 451 & 5 & 1992 Strasser \\
451005 & 451 & 1 & 1996 Bio \\
451006 & 451 & 5 & 1997 Koroma \\
452001 & 452 & 2 & 1966 Ankrah \\
452002 & 452 & 4 & 1969 Afrifa \\
452003 & 452 & 9 & 1969 Busia \\
452004 & 452 & 1 & 1972 Acheampong \\
452005 & 452 & 7 & 1978 Akuffo \\
452006 & 452 & 6 & 1979 Rawlings \\
452007 & 452 & 12 & 1981 Rawlings \\
461001 & 461 & 1 & 1963 Grunitzky \\
461002 & 461 & 1 & 1967 Dadjo \\
461003 & 461 & 4 & 1967 Eyadema \\
461004 & 461 & 2 & 2005 Faure Gnassingbe \\
461005 & 461 & 2 & 2005 Bonfoh \\
461006 & 461 & 5 & 2005 Faure Gnassingbe \\
471001 & 471 & 1 & 1960 Ahidjo \\
471002 & 471 & 11 & 1982 Biya \\
475001 & 475 & 1 & 1966 Ironsi \\
475002 & 475 & 7 & 1966 Gowon \\
475003 & 475 & 7 & 1975 Ramat Mohammed \\
475004 & 475 & 2 & 1976 Obasanjo \\
475005 & 475 & 12 & 1983 Buhari \\
475006 & 475 & 8 & 1985 Babangida \\
475007 & 475 & 8 & 1993 Shonekan \\
475008 & 475 & 11 & 1993 Abacha \\
475009 & 475 & 6 & 1998 Abubakar \\
481001 & 481 & 8 & 1960 Mba \\
481002 & 481 & 11 & 1967 Bongo \\
481003 & 481 & 6 & 2009 Rogombe \\
481004 & 481 & 10 & 2009 Ondimba \\
482001 & 482 & 8 & 1960 Dacko \\
482002 & 482 & 1 & 1966 Bokassa \\
482003 & 482 & 9 & 1979 Dacko \\
482004 & 482 & 9 & 1981 Kolingba \\
482005 & 482 & 3 & 2003 Francois Bozize \\
482006 & 482 & 3 & 2013 Djotidia \\
482007 & 482 & 1 & 2014 Nguendet \\
482008 & 482 & 1 & 2014 Samba-Panza \\
& & & \\
\hline
\end{tabular}

1987 Reshuffle Coup 2014 Regime-Change Coup 2014 Regime-Change Coup 1980 Regular Election/Selection 1980 Regular Election/Selectio 1990 Regime-Change Coup 1994 Foreign Installation 1995 First Election/Selection 1996 Regular Election/Selection 1997 Regular Election/Selection 2003 Regular Election/Selection 2003 Forced Election/Selection 2006 First Election/Selection 1968 Regime-Change Coup 1985 Regime-Change Coup 1992 First Election/Selection 1996 Regime-Change Coup 1996 Reshuffle Coup

1998 Regime-Change Coup 969 Regime-Change Coup 1972 Regular Election/Selection 1978 Regime-Change Coup 1979 Reshuffle Coup

1979 Regime-Change Coup 2001 Regime-Change Coup

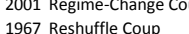
1967 Reshuffle Coup 2005 Reshuffle Coup 2005 Regular Election/Selection 005 Regular Election/Selection Regular Election/Selectio 1982 First Election/Selection Regular Election/Selection 1966 Regime-Change Coup 1975 Reshuffle Coup 1976 Reshuffle Coup 1979 Forced Election/Selection 1985 Regime-Change Coup 1993 Reshuffle Coup 1993 First Election/Selection 1998 Reshuffle Coup 1999 First Election/Selection 1967 First Election/Selection 2009 Regular Election/Selection 2009 Regular Election/Selection Regular Election/Selection 1966 First Election/Selection 1979 Regime-Change Coup 1981 Foreign Installation 1993 Regime-Change Coup 2013 Successful Rebellio 2014 Successful Rebellion 2014 First Election/Selection 2016 Regular Election/Selection
Regime-Change Coup Irregula Voluntary Resignation Regular Regular Regime-Change Coup Regular Military Coup Rebellion Irregular Voluntary Resignation Foreign Regular Voluntary Resignation Regular Voluntary Resignation Regular Regular Regular Voluntary Resignation Regular Voluntary Resignation Regular Regime-Change Coup Irregular Military Coup Voluntary Resignation Irregular Regular $\begin{array}{lll}\text { Regime-Change Coup Regular Military Coup } & \\ \text { Reshuffle Coup } & \text { Miltary Coup }\end{array}$ Voluntary Resignation Irregular Regular Foreign Overthrow Irregular Foreign Legal Removal Irregular Regular Voluntary Resignation Regular Regular Regime-Change Coup Regular Military Coup Reshuffle Coup Coup Resime Change Coup regur Regime-Change Coup Regular Voluntary Resignation Irregular Voluntary Resignation Irregular $\begin{array}{ll}\text { Reshuffle Coup } & \text { Irregular } \\ \text { Voluntary Resignation } & \text { Irregular }\end{array}$ $\begin{array}{ll}\text { Voluntary Resignation } & \text { Irregular } \\ \text { Irregular }\end{array}$ Irregular Voluntary Resignation Regular Voluntary Resignation Regular Still in Power Regular Voluntary Resignation Regular Still in Power Regular Reshuffle Coup Irregular Reshuffle Coup Irregular Assassination Irregular Voluntary Resignation Irregular Reshuffle Coup Irregular Voluntary Resignation Irregular Reshuffle Coup Irregular Natural Death Irregular Voluntary Resignation Regular Natural Death Regular Natural Death Regular Voluntary Resignation Regular $\begin{array}{ll}\text { Voluntary Resignation } & \text { Regular } \\ \text { Still in Power } & \text { Regular }\end{array}$ Regime-Change Coup Regular $\begin{array}{ll}\text { Foreign Overthrow } & \text { Irregular }\end{array}$ $\begin{array}{ll} & \\ \text { Regime-Change Coup } & \text { Fregular }\end{array}$ $\begin{array}{ll}\text { Regime-Change Coup } & \text { Foreign } \\ \text { Voluntary Resignation } & \text { Irregular }\end{array}$ Voluntary Resignation Irregular $\begin{array}{ll}\text { Rebellion } & \text { Regular } \\ \text { Voluntary Resignation } & \text { Irregular }\end{array}$ $\begin{array}{ll}\text { Voluntary Resignation } & \text { Irregular } \\ \text { Voluntary Resignation } & \text { Regular }\end{array}$ $\begin{array}{ll}\text { Voluntary Resignation } & \text { Regular } \\ \text { Voluntary Resignation } & \text { Regular }\end{array}$
Removed by Military Power Struggle Military Coup Regula Regular
Military Coup Removed by Military Power Struggle Natural Death

Regular

Regular
Still in Office

Retired Due to III Health

Still in Office

Military Coup

Military Coup

Military Coup Regular

Military Coup

Regular

Military Coup

Natural D
Regular

Irregular, Other

Natural Death

Regular

Still in Office

Military Coup

Foreign

Military Coup

Regular

Rebellion

Regular

Regular
Still in Office 


\begin{tabular}{llrl}
483001 & 483 & 8 & 1960 Tombalbaye \\
483002 & 483 & 4 & 1975 Malloum \\
483003 & 483 & 3 & 1979 Oeddei \\
483004 & 483 & 6 & 1982 Habre \\
483005 & 483 & 12 & 1990 Deby \\
484001 & 484 & 8 & 1960 Youlou \\
484002 & 484 & 8 & 1963 Debat \\
484003 & 484 & 9 & 1968 Raoul \\
484004 & 484 & 1 & 1969 Ngouabi \\
484005 & 484 & 3 & 1977 Opango \\
484006 & 484 & 2 & 1979 Nguesso \\
484007 & 484 & 10 & 1997 gguesso \\
490001 & 490 & 9 & 1960 Kasavubu \\
490002 & 490 & 11 & 1965 Mobutu \\
490003 & 490 & 5 & 1997 Laurent Kabila \\
490004 & 490 & 1 & 2001 Joseph Kabila \\
500001 & 500 & 10 & 1962 Obote \\
500002 & 500 & 1 & 1971 Amin \\
500003 & 500 & 4 & 1979 Yusuf Lule \\
500004 & 500 & 6 & 1979 Binaisa \\
500005 & 500 & 5 & 1980 Paulo Muwanga \\
500006 & 500 & 12 & 1980 Obote \\
500007 & 500 & 7 & 1985 Okello \\
500008 & 500 & 1 & 1986 Museveni \\
501001 & 501 & 12 & 1963 Kenyatta \\
501002 & 501 & 8 & 1978 Moi \\
510001 & 510 & 11 & 1961 Nyerere \\
510002 & 510 & 11 & 1985 Mwinyi \\
510003 & 510 & 11 & 1995 Mkapa \\
510004 & 510 & 12 & 2005 Kikwete \\
510005 & 510 & 11 & 2015 Magufuli \\
516001 & 516 & 7 & 1962 Mwambutsa \\
516002 & 516 & 7 & 1966 Ntare \\
516003 & 516 & 11 & 1966 Micombero \\
516004 & 516 & 11 & 1976 Bagaza \\
516005 & 516 & 9 & 1987 Buyoya \\
516006 & 516 & 7 & 1996 Buyoya \\
516007 & 516 & 4 & 2003 Ndayizeye \\
517001 & 517 & 10 & 1961 Kayibanda \\
517002 & 517 & 7 & 1973 Habyarimana \\
517003 & 517 & 4 & 1994 Sindikubwabo \\
517004 & 517 & 7 & 1994 Paul Kagame \\
520001 & 520 & 10 & 1969 Siad Barre \\
522001 & 522 & 6 & 1977 Gouled Aptidon \\
522002 & 522 & 5 & 1999 Guelleh \\
530001 & 530 & 9 & 1974 Andom \\
530002 & 530 & 11 & 1974 Banti \\
530003 & 530 & 2 & 1977 Mengistu Marriam \\
530004 & 530 & 5 & 1991 Gebre Kidan \\
530005 & 530 & 5 & 1991 Meles Zenawi \\
530006 & 530 & 8 & 2012 Desalegn \\
531001 & 531 & 5 & 1993 Afeworki \\
540001 & 540 & 11 & 1975 Neto \\
540002 & 540 & 9 & 1979 Dos Santos \\
541001 & 541 & 6 & 1975 Machel \\
& & & \\
\hline
\end{tabular}

1975 First Election/Selection 1979 Regime-Change Coup 1982 Successful Rebellion Successful Rebellio Successful Rebellion 1963 First Election/Selection 1968 Forced Election/Selection 1969 Reshuffle Coup 1977 First Election/Selection 1979 Forced Election/Selection 992 Forced Election/Selection Successful Rebellio

1965 First Election/Selection

1997 Regime-Change Coup

2001 Successful Rebellion Forced Election/Selection

1971 First Election/Selection

1979 Regime-Change Coup

1979 Foreign Installation

1980 First Election/seloction

(1)

985 First Election/Selectio

1986 Reshuffle Coup Successful Rebellio

1978 First Election/Selection

2002 Regular Election/Selection

1985 First Election/Selection

1995 Regular Election/Selection

2005 Regular Election/Selection

15 Regular Election/Selection Regular Election/Selection

1966 First Election/Selection

1966 Reshuffle Coup

1976 Regime-Change Coup

1987 Reshuffle Coup

1993 Regime-Change Coup

2003 Regime-Change Coup

2005 First Election/Selection

1973 First Election/Selection

1994 Regime-Change Coup

1994 Forced Election/Selection Successful Rebellion

1991 Regime-Change Coup

1999 First Election/Selection Regular Election/Selection 1974 Regime-Change Coup

1977 Forced Election/Selection 1991 Reshuffle Coup

1991 Forced Election/Selection 2012 Successful Rebellion First Election/Selection Successful Rebellion

1979 Successful Rebellion First Election/Selection

Regime-Change Coup Regular Rebellion Irregular

Rebellion

till in Power

Protest

Reshuffle Coup

Voluntary Resignation

Assassination

Legal Removal

Voluntary Resignation

Still in Power

Regime-Change Coup

Rebellion

till in Power

Regime-Change Coup

oreign Overthrow

Voluntary Resignation

Voluntary Resignation

Reshuffle Coup

Rebellion

Stillin

Still in Power

Natural Death

Voluntary Resignation

Voluntary Resignation

Voluntary Resignation

Voluntary Resignation

Regular

(1ilin Power

Reshuffle Coup

Regime-Change Coup

Reshuffle Coup

Regime-Change Coup

oluntary Resignation

Voluntary Resignation

Roluntary Resignation

Reshuffle Coup

Rebellion

Still in Pow

Rebellion

Voluntary Resignation

till in Power

Assassination

Ashilion

Rebellion

Rebellion
Natural Death

Natural Death
Still in Power

Still in Power
Still in Power

Natural Death

Still in Power

Natural Death
Military Coup

Rebellion

Rebellion
Rebellion

Still in Office

Protest

Military Coup

Regular

Military Coup

Removed by Military Power Struggle

Regular

Still in Office

Military Coup

Regular

Military Coup

Still in Office

Military Coup

Foreign

Regular

Military Coup

Regular

Military Coup

Rebellion

Natural Death

Natural De
Regular

Regular
Regular

Regular

Regula

Still in Office

Removed by Other Government Actor

Military Coup

Military Coup

Military Coup

Regular

Regular

Regular

Military Coup

Irregular, Other

Regular

Still in Office

Rebellion

Regular
Still in Office

Removed by Military Power Struggle

Removed by

Reny

Rebellon

Rebelion

Natural Death

Still in Office

Still in Office

Natural Death

Still in Office

Natural Death 


\begin{tabular}{lrrl}
541002 & 541 & 11 & 1986 Chissano \\
51003 & 541 & 2 & 2005 Guebuza \\
51004 & 541 & 1 & 2015 Nyussi \\
551001 & 551 & 10 & 1964 Kaunda \\
551002 & 551 & 1 & 2002 Levy Mwanawasa \\
551003 & 551 & 8 & 2008 Banda \\
552001 & 552 & 11 & 1965 Smith \\
552002 & 552 & 5 & 1979 Muzorewa \\
552003 & 552 & 3 & 1980 Mugabe \\
553001 & 553 & 7 & 1964 Banda \\
560001 & 560 & 12 & 1954 Strijdom \\
560002 & 560 & 8 & 1958 Swart \\
560003 & 560 & 9 & 1958 Verwoerd \\
560004 & 560 & 9 & 1966 Donges \\
560005 & 560 & 9 & 1966 Vorster \\
560006 & 560 & 9 & 1978 Botha \\
560007 & 560 & 1 & 1989 Heunis \\
560008 & 560 & 3 & 1989 Botha \\
560009 & 560 & 8 & 1989 deKlerk \\
565001 & 565 & 3 & 1990 Nujoma \\
565002 & 565 & 3 & 2005 Pohamba \\
565003 & 565 & 3 & 2015 Geingob \\
570001 & 570 & 1 & 1986 Lekhanya \\
570002 & 570 & 5 & 1991 Ramaema \\
571001 & 571 & 9 & 1966 Khama \\
571002 & 571 & 7 & 1980 Masire \\
571003 & 571 & 3 & 1998 Mogae \\
571004 & 571 & 3 & 2008 lan Khama \\
572001 & 572 & 9 & 1968 Subhuza II \\
572002 & 572 & 8 & 1982 Dzeliwe Shongwe \\
572003 & 572 & 8 & 1983 Ntombe Thwala \\
572004 & 572 & 4 & 1986 Mswati \\
580001 & 580 & 6 & 1960 Tsiranana \\
580002 & 580 & 10 & 1972 Ramanantsoa \\
580003 & 580 & 2 & 1975 Ratsimandrava \\
580004 & 580 & 2 & 1975 Gilles Andriamahazo \\
580005 & 580 & 6 & 1975 Ratsiraka \\
580006 & 580 & 3 & 2009 Rajoelina \\
581001 & 581 & 7 & 1975 Abdallah \\
581002 & 581 & 8 & 1975 Soilih \\
581003 & 581 & 5 & 1978 Bob Denard \\
581004 & 581 & 12 & 1989 Djohar \\
581005 & 581 & 9 & 1995 Bob Denard \\
581006 & 581 & 10 & 1995 el-Yachroutu \\
581007 & 581 & 1 & 1996 Djohar \\
581008 & 581 & 3 & 1996 Abdoulkarim \\
581009 & 581 & 11 & 1998 Massounde \\
581010 & 581 & 4 & 1999 Azali Assoumani \\
581011 & 581 & 1 & 2002 Hamada Madi \\
581012 & 581 & 5 & 2002 Azali Assoumani \\
591001 & 591 & 4 & 2004 Michel \\
600001 & 600 & 3 & 1956 Mohammed V \\
600002 & 600 & 2 & 1961 Hassan II \\
600003 & 600 & 7 & 1999 Muhammad VI \\
615001 & 615 & 7 & 1962 Ben Khedda \\
& & & \\
\hline
\end{tabular}

\begin{tabular}{|c|c|c|c|c|}
\hline 2005 & First Election/Selection & Voluntary Resignation & Regular & Regular \\
\hline 2015 & Regular Election/Selection & Voluntary Resignation & Regular & Regular \\
\hline & Regular Election/Selection & Still in Power & Regular & Still in Office \\
\hline 1991 & First Election/Selection & Voluntary Resignation & Regular & Regular \\
\hline 2008 & First Election/Selection & Natural Death & Regular & Retired Due to III Health \\
\hline 2011 & Regular Election/Selection & Voluntary Resignation & Regular & Regular \\
\hline 1979 & Regular Election/Selection & Rebellion & Regular & Regular \\
\hline 1979 & Successful Rebellion & Voluntary Resignation & Regular & Regular \\
\hline & First Election/Selection & Still in Power & Regular & Still in Office \\
\hline 1994 & First Election/Selection & Voluntary Resignation & Regular & Regular \\
\hline 1958 & Regular Election/Selection & Voluntary Resignation & Regular & Natural Death \\
\hline 1958 & Regular Election/Selection & Voluntary Resignation & Regular & Regular \\
\hline 1966 & Regular Election/Selection & Assassination & Regular & Assassination by Unsupported Individual \\
\hline 1966 & Forced Election/Selection & Voluntary Resignation & Regular & Regular \\
\hline 1978 & Regular Election/Selection & Voluntary Resignation & Regular & Regular \\
\hline 1989 & Regular Election/Selection & Voluntary Resignation & Regular & Regular \\
\hline 1989 & Regular Election/Selection & Voluntary Resignation & Regular & Regular \\
\hline 1989 & Regular Election/Selection & Voluntary Resignation & Regular & Regular \\
\hline 1994 & Regular Election/Selection & Voluntary Resignation & Regular & Regular \\
\hline 2005 & Successful Rebellion & Voluntary Resignation & Regular & Regular \\
\hline 2015 & First Election/Selection & Voluntary Resignation & Regular & Regular \\
\hline & Regular Election/Selection & Still in Power & Regular & Still in Office \\
\hline 1991 & Regime-Change Coup & Reshuffle Coup & Irregular & Military Coup \\
\hline 1993 & Reshuffle Coup & Voluntary Resignation & Irregular & Regular \\
\hline 1980 & First Election/Selection & Natural Death & Regular & Natural Death \\
\hline 1998 & Regular Election/Selection & Voluntary Resignation & Regular & Regular \\
\hline 2008 & Regular Election/Selection & Voluntary Resignation & Regular & Regular \\
\hline & Regular Election/Selection & Still in Power & Regular & Still in Office \\
\hline 1982 & First Election/Selection & Natural Death & Regular & Natural Death \\
\hline 1983 & Regular Election/Selection & Reshuffle Coup & Regular & Removed by Other Government Actors \\
\hline 1986 & Reshuffle Coup & Voluntary Resignation & Regular & Regular \\
\hline & First Election/Selection & Still in Power & Regular & Still in Office \\
\hline 1972 & First Election/Selection & Protest & Regular & Protest \\
\hline 1975 & Forced Election/Selection & Legal Removal & Irregular & Removed by Military Power Struggle \\
\hline 1975 & Forced Election/Selection & Assassination & Irregular & Military Coup \\
\hline 1975 & Forced Election/Selection & Voluntary Resignation & Irregular & Regular \\
\hline 1993 & First Election/Selection & Voluntary Resignation & Regular & Regular \\
\hline 2014 & Regime-Change Coup & Voluntary Resignation & Irregular & Regular \\
\hline 1975 & First Election/Selection & Foreign Overthrow & Irregular & Rebellion \\
\hline 1978 & Foreign Installation & Foreign Overthrow & Irregular & Military Coup \\
\hline 1989 & Foreign Installation & Reshuffle Coup & Irregular & Removed by Other Government Actors \\
\hline 1995 & Forced Election/Selection & Regime-Change Coup & Regular & Military Coup \\
\hline 1995 & Regime-Change Coup & Voluntary Resignation & Irregular & Foreign \\
\hline 1996 & First Election/Selection & Voluntary Resignation & Regular & Regular \\
\hline 1996 & Forced Election/Selection & Voluntary Resignation & Regular & Regular \\
\hline 1998 & First Election/Selection & Natural Death & Regular & Natural Death \\
\hline 1999 & Regular Election/Selection & Reshuffle Coup & Regular & Military Coup \\
\hline 2002 & Reshuffle Coup & Voluntary Resignation & Irregular & Regular \\
\hline 2002 & First Election/Selection & Voluntary Resignation & Regular & Regular \\
\hline 2006 & Regular Election/Selection & Voluntary Resignation & Regular & Regular \\
\hline & Regular Election/Selection & Still in Power & NA & NA \\
\hline 1961 & First Election/Selection & Natural Death & Irregular & Natural Death \\
\hline 1999 & Regular Election/Selection & Natural Death & Regular & Natural Death \\
\hline & Regular Election/Selection & Still in Power & Regular & Still in Office \\
\hline $1962 \mathrm{~F}-2-2$ & First Election/Selection & Voluntary Resignation & Regular & Regular \\
\hline
\end{tabular}




\begin{tabular}{|c|c|c|c|}
\hline 615002 & 615 & 9 & 1962 Bella \\
\hline 615003 & 615 & 6 & 1965 Boumedienne \\
\hline 615004 & 615 & 12 & 1978 Bitat \\
\hline 615005 & 615 & 2 & 1979 Benjedid \\
\hline 615006 & 615 & 1 & 1992 Boudiaf \\
\hline 615007 & 615 & 7 & $1992 \mathrm{Kafi}$ \\
\hline 615008 & 615 & 1 & 1994 Zeroual \\
\hline 615009 & 615 & 4 & 1999 Bouteflika \\
\hline 616001 & 616 & 2 & 1956 Muhammad al-Amin \\
\hline 616002 & 616 & 7 & 1957 Ben Ali Bourguiba \\
\hline 616003 & 616 & 11 & 1987 Zine Al-Abidine Ben Ali \\
\hline 616004 & 616 & 1 & 2011 Mebazaa \\
\hline 616005 & 616 & 12 & 2011 Marzouki \\
\hline 620001 & 620 & 12 & 1951 Idris \\
\hline 620002 & 620 & 9 & 1969 Qaddafi \\
\hline 625001 & 625 & 11 & 1958 Abboud \\
\hline 625002 & 625 & 11 & 1964 al-Khalifa \\
\hline 625003 & 625 & 5 & 1969 Nimeiri \\
\hline 625004 & 625 & 4 & 1985 Abdul Rahman Swaredahab \\
\hline 625005 & 625 & 6 & 1989 Al-Bashir \\
\hline 626001 & 626 & 7 & 2011 Kiir \\
\hline 630001 & 630 & 4 & 1951 Mohammad Mossadeg \\
\hline 630002 & 630 & 8 & 1953 Mohammad Reza \\
\hline 630003 & 630 & 2 & 1979 Ayatollah Khomeini \\
\hline 630004 & 630 & 6 & 1989 Khamenei \\
\hline 630005 & 630 & 8 & 1989 Rafsanjani \\
\hline 630006 & 630 & 8 & 1997 Khatami \\
\hline 630007 & 630 & 8 & 2005 Ahmadinejad \\
\hline 630008 & 630 & 8 & 2013 Rouhani \\
\hline 640001 & 640 & 5 & 1960 Gursel \\
\hline 640002 & 640 & 9 & 1980 Evren \\
\hline 645001 & 645 & 5 & 1953 Faisal II \\
\hline 645002 & 645 & 7 & 1958 Karrim Kassem \\
\hline 645003 & 645 & 2 & 1963 Salem Aref \\
\hline 645004 & 645 & 4 & 1966 Rahmen Aref \\
\hline 645005 & 645 & 7 & 1968 Hassan Al-Bakr \\
\hline 645006 & 645 & 7 & 1979 Saddam Hussein \\
\hline 645007 & 645 & 4 & 2003 Tommy Ray Franks \\
\hline 645008 & 645 & 4 & 2003 Jay Garner \\
\hline 645009 & 645 & 5 & 2003 Paul Bremer \\
\hline 645010 & 645 & 6 & 2004 Iyad Allawi \\
\hline 645011 & 645 & 5 & 2005 al-Jaafari \\
\hline 645012 & 645 & 5 & 2006 al-Maliki \\
\hline 651001 & 651 & 7 & 1952 Naguib \\
\hline 651002 & 651 & 11 & 1954 Nasser \\
\hline 651003 & 651 & 9 & 1970 Sadat \\
\hline 651004 & 651 & 10 & 1981 Mubarak \\
\hline 651005 & 651 & 2 & 2011 Tantawi \\
\hline 651006 & 651 & 7 & 2013 Mansour \\
\hline 651007 & 651 & 6 & 2014 al-Sisi \\
\hline 652001 & 652 & 2 & 1958 Nasser (president of UAR) \\
\hline 652002 & 652 & 9 & 1961 Al-kuzbari \\
\hline 652003 & 652 & 12 & 1961 El-Kudsi \\
\hline 652004 & 652 & 3 & 1962 Zahreddin \\
\hline 652005 & 652 & 4 & 1962 El-Kudsi \\
\hline
\end{tabular}

\begin{tabular}{|c|c|c|c|}
\hline 1965 Regular Election/Selection & Reshuffle Coup & Regular & Military Coup \\
\hline 1978 Reshuffle Coup & Natural Death & Irregular & Natural Death \\
\hline 1979 First Election/Selection & Voluntary Resignation & Regular & Regular \\
\hline 1992 Regular Election/Selection & Regime-Change Coup & Regular & Military Coup \\
\hline 1992 Regime-Change Coup & Assassination & Irregular & Rebellion \\
\hline 1994 Forced Election/Selection & Voluntary Resignation & Regular & Regular \\
\hline 1999 First Election/Selection & Voluntary Resignation & Regular & Regular \\
\hline Regular Election/Selection & Still in Power & Regular & Still in Office \\
\hline 1957 First Election/Selection & Legal Removal & Regular & Removed by Other Government Actors \\
\hline 1987 Forced Election/Selection & Reshuffle Coup & Irregular & Removed by Other Government Actors \\
\hline 2011 Reshuffle Coup & Protest & Irregular & Protest \\
\hline 2011 Forced Election/Selection & Voluntary Resignation & Regular & Regular \\
\hline 2014 First Election/Selection & Voluntary Resignation & Regular & Regular \\
\hline 1969 First Election/Selection & Regime-Change Coup & Regular & Military Coup \\
\hline 2011 Regime-Change Coup & Foreign Overthrow & Irregular & Rebellion \\
\hline 1964 Regime-Change Coup & Protest & Irregular & Protest \\
\hline 1965 Successful Protest & Voluntary Resignation & Irregular & Regular \\
\hline 1985 Regime-Change Coup & Regime-Change Coup & Irregular & Military Coup \\
\hline 1986 Regime-Change Coup & Voluntary Resignation & Irregular & Regular \\
\hline Regime-Change Coup & Still in Power & Irregular & Still in Office \\
\hline Forced Election/Selection & Still in Power & Regular & Still in Office \\
\hline 1953 First Election/Selection & Foreign Overthrow & Irregular & Removed by Other Government Actors \\
\hline 1979 Foreign Installation & Protest & Irregular & Protest \\
\hline 1989 Successful Protest & Natural Death & Irregular & Natural Death \\
\hline 1989 First Election/Selection & Voluntary Resignation & Regular & Regular \\
\hline 1997 Regular Election/Selection & Voluntary Resignation & Regular & Regular \\
\hline 2005 Regular Election/Selection & Voluntary Resignation & Regular & Regular \\
\hline 2013 Regular Election/Selection & Voluntary Resignation & Regular & Regular \\
\hline Regular Election/Selection & Still in Power & Regular & Still in Office \\
\hline 1961 Reshuffle Coup & Voluntary Resignation & Irregular & Regular \\
\hline 1983 Regime-Change Coup & Voluntary Resignation & Irregular & Regular \\
\hline 1958 Regular Election/Selection & Regime-Change Coup & Regular & Military Coup \\
\hline 1963 Regime-Change Coup & Regime-Change Coup & Irregular & Military Coup \\
\hline 1966 Regime-Change Coup & Natural Death & Irregular & Natural Death \\
\hline 1968 First Election/Selection & Reshuffle Coup & Regular & Military Coup \\
\hline 1979 Reshuffle Coup & Voluntary Resignation & Irregular & Regular \\
\hline 2003 Regular Election/Selection & Foreign Overthrow & Regular & Foreign \\
\hline 2003 Foreign Installation & Voluntary Resignation & Foreign & Regular \\
\hline 2003 Foreign Installation & Voluntary Resignation & Foreign & Regular \\
\hline 2004 Foreign Installation & Voluntary Resignation & Foreign & Regular \\
\hline 2005 Forced Election/Selection & Voluntary Resignation & Regular & Regular \\
\hline 2006 First Election/Selection & Voluntary Resignation & Regular & Regular \\
\hline 2014 Regular Election/Selection & Voluntary Resignation & Regular & Regular \\
\hline 1954 Regime-Change Coup & Legal Removal & Irregular & Regular \\
\hline 1970 Forced Election/Selection & Natural Death & Regular & Natural Death \\
\hline 1981 First Election/Selection & Assassination & Regular & Irregular, Other \\
\hline 2011 Forced Election/Selection & Reshuffle Coup & Regular & Protest \\
\hline 2012 Reshuffle Coup & Voluntary Resignation & Regular & Regular \\
\hline 2014 First Election/Selection & Regime-Change Coup & Irregular & Regular \\
\hline Regime-Change Coup & Still in Power & Regular & Still in Office \\
\hline 1961 First Election/Selection & Regime-Change Coup & Regular & Military Coup \\
\hline 1961 Regime-Change Coup & Voluntary Resignation & Irregular & Regular \\
\hline 1962 First Election/Selection & Reshuffle Coup & Regular & Military Coup \\
\hline 1962 Reshuffle Coup & Reshuffle Coup & Irregular & Regular \\
\hline 1963 Reshuffle Coup & Regime-Change Coup & Regular & Military Coup \\
\hline
\end{tabular}




$\begin{array}{llrl}652006 & 652 & 3 & 1963 \text { Atassi, L. } \\ 652007 & 652 & 7 & 1963 \text { Al-Hafiz } \\ 652008 & 652 & 2 & 1966 \text { El-Atassi, N. } \\ 652009 & 652 & 11 & 1970 \text { Al-Khatib } \\ 652010 & 652 & 2 & 1971 \text { Al-Assad H. } \\ 652011 & 652 & 6 & 2000 \text { Bashar al-Assad } \\ 660001 & 660 & 9 & 1976 \text { Sarkis } \\ 660002 & 660 & 9 & 1982 \text { Gemayel, Amin } \\ 660003 & 660 & 9 & 1988 \text { Aoun } \\ 660004 & 660 & 11 & 1989 \text { Moawad } \\ 660005 & 660 & 11 & 1989 \text { Elias Hrawi } \\ 660006 & 660 & 11 & 1998 \text { Emile Lahoud } \\ 663001 & 663 & 7 & 1951 \text { Abdullah El-Hashim } \\ 663002 & 663 & 9 & 1951 \text { Ibn Abdullah-Hashim } \\ 663003 & 663 & 8 & 1952 \text { Hussein Ibn Talal El-Hashim } \\ 663004 & 663 & 2 & 1999 \text { Abdullah Ibn Hussein El-Hashimi } \\ 670001 & 670 & 11 & 1953 \text { Saud } \\ 670002 & 670 & 11 & 1964 \text { Faisal } \\ 670003 & 670 & 3 & 1975 \text { Khalid } \\ 670004 & 670 & 6 & 1982 \text { Fahd } \\ 670005 & 670 & 1 & 1996 \text { Abdullah } \\ 670006 & 670 & 1 & 2015 \text { Salman } \\ 678001 & 678 & 9 & 1962 \text { Al-Badr } \\ 678002 & 678 & 9 & 1962 \text { AL-Sallal } \\ 678003 & 678 & 11 & 1967 \text { Al-Iryani } \\ 678004 & 678 & 6 & 1974 \text { Al-Hamadi } \\ 678005 & 678 & 10 & 1977 \text { Al-Ghashmi } \\ 678006 & 678 & 7 & 1978 \text { Saleh al-Hashidi } \\ 679001 & 679 & 5 & 1990 \text { Saleh al-Hashidi } \\ 679002 & 679 & 2 & 2012 \text { Hadi } \\ 679003 & 679 & 2 & 2015 \text { Houthi } \\ 680001 & 680 & 11 & 1967 \text { Al-Shaabi } \\ 680002 & 680 & 6 & 1969 \text { Ali Rubayyi } \\ 680003 & 680 & 6 & 1978 \text { Ali Nassir Hassani } \\ 680004 & 680 & 12 & 1978 \text { Ismail } \\ 680005 & 680 & 4 & 1980 \text { Ali Nassir Hassani } \\ 680006 & 680 & 1 & 1986 \text { Attas } \\ 690001 & 690 & 1 & 1950 \text { Abdullah As-Sabah } \\ 690002 & 690 & 11 & 1965 \text { Sabah As-Sabah } \\ 690003 & 690 & 1 & 1978 \text { Jabir As-Sabah } \\ 690004 & 690 & 8 & 1990 \text { Saddam Hussein } \\ 690005 & 690 & 4 & 1991 \text { Jabir As-Sabah } \\ 690006 & 690 & 1 & 2006 \text { Saad Salim at Sabah } \\ 690007 & 690 & 1 & 2006 \text { Jabir Ahmad Al Sabah } \\ 692001 & 692 & 8 & 1971 \text { Isa Ibn Al-Khalifah } \\ 692002 & 692 & 3 & 1999 \text { Hamad Isa lbn Al-Khalifah } \\ 694001 & 694 & 9 & 1971 \text { Ahmed Ath-Thani } \\ 694002 & 694 & 2 & 1972 \text { Khalifah Ath-Thani } \\ 694003 & 694 & 6 & 1995 \text { Amad Al Thani } \\ 694004 & 694 & 6 & 2013 \text { Tamim Al Thani } \\ 696001 & 696 & 12 & 1971 \text { An-Nahayan } \\ 696002 & 696 & 11 & 2004 \text { Khalifa Al Nahayan } \\ 698001 & 698 & 7 & 1970 \text { Qabus Bin Said } \\ 700001 & 700 & 9 & 1953 \text { Sardar Mohammad Daud Khan } \\ 700002 & 700 & 3 & 1963 \text { Mohammad Yusuf } \\ & & & \end{array}$

1963 Regime-Change Coup 1966 Forced Election/Selectio 1970 Reshuffle Coup 2000 First Election/Selection Regular Election/Selection 982 Regular Election/Selection 988 Forced Election/Selection 1989 Regular Election/Selectio 1989 Regular Election/Selection 1998 Forced Election/Selection 2007 Regular Election/Selection 1951 Forced Election/Selection 1952 First Election/Selection 1999 Regular Election/Selection Regular Election/Selection 1964 First Election/Selection 1975 Reshuffle Coup 1982 Forced Election/Selection 1996 Regular Election/Selection 2015 Regular Election/Selection Regular Election/Selection 1962 Regular Election/Selection 1967 Regime-Change Coup 1974 Regime-Change Coup Regime-Change Coup 978 Forced Election/Selection 1990 Forced Election/Selection 2012 First Election/Selection 2015 Regular Election/Selection Successful Rebellio 1969 First Election/Selection 1978 Reshuffle Coup 1978 Successful Rebellion 1980 First Election/Selection 1986 Regular Election/Selection 1990 Reshuffle Coup

1965 First Election/Selection 1977 Regular Election/Selection 1990 Regular Election/Selection 1991 Foreign Installation 2006 Foreign Installation 2006 First Election/Selection Regular Election/Selection 1999 First Election/Selection Regular Election/Selection 972 Regular Election/Section/Selection

1995 Reshuffle Coup 1995 Reshuffle Coup

First Election/Selection
.

2004 First Election/Selection Regular Election/Selection Reshuffle Coup

1963 Forced Election/Selection 1965 Forced Election/Selection
Voluntary Resignation Reshuffle Coup Irregular Reshuffle Coup Irregula Natural Death $\quad$ Regular Still in Power Regular Voluntary Resignation Regular Voluntary Resignation Regular Voluntary Resignation Regular Assassination Regular Voluntary Resignation Regular Voluntary Resignation Regular Voluntary Resignation Regular Voluntary Resignation Natural Death Still in Power Reshuffle Coup Assassination Natural Death Voluntary Resignation Still in Death Regular Regular Regime-Change Coup Irregular Regime-Change Coup Irregular $\begin{array}{ll}\text { Regime-Change Coup } & \text { Irregular } \\ \text { Assassination } & \text { Irregular }\end{array}$ Assassination

Assassination Regular Voluntary Resignation Regular Voluntary Resignation Irregular Rebellion NA in Power Reshuffle Coup Irregular Voluntary Resignation Irregul Voluntary Resignation Regular Reshuffle Coup Regular Voluntary Resignation Irregular Natural Death Regular Natural Death Regular Foreign Overthrow Regular Foreign Overthrow Foreign Natural Death Foreign Voluntary Resignation Regular Still in Power Regular Natural Death Regular Still in Power Regular $\begin{array}{ll}\text { Reshuffle Coup } & \text { Regular } \\ \text { Regular }\end{array}$ $\begin{array}{ll}\text { Reshuffle Coup } & \text { Regular } \\ \text { Reshuffle Coup } & \text { Irregular }\end{array}$ Voluntary Resignation Irregular Still in Power Regular Natural Death Regular Still in Power Regular Still in Power Irregular $\begin{array}{ll}\text { Legal Removal } & \text { Irregular } \\ \text { Voluntary Resignation } & \text { Regular }\end{array}$
Removed by Military Power Struggle Military Coup Military Coup Regular

Natural Death

Still in Offic

Regular

Regular

Regular

Rebellion

Regular

Regular

Regular

Regular

Natural Death

Still in Office

Regular

Assassination by Unsupported Individual

Natural Death

Retired Due to III Health

Natural Death

Natural Death

Military Coup

Military Coup

Military Coup

Irregular, Other

sination by Unsupported Individual Regular

Regular
Still in Office

NA

Removed by Other Government Actor Rebellion

Regular

Regular

Irregular, Other

Regular

Natural Death

Natural Death

Foreign

Natural Death

Regular

Still in Office

Still in Office

Natural Death

Other Government Actors by Other Government Actors Regular

Still in Office

Natural Death

Still in Office

Still in Office

Regula

Regular 


$\begin{array}{lrrl}700003 & 700 & 11 & \text { 1965 Mohammad Hashim Maiwandwal } \\ 700004 & 700 & 10 & 1967 \text { Abdallah Yakta } \\ 700005 & 700 & 11 & 1967 \text { Nur Ahmad Etemadi } \\ 700006 & 700 & 6 & 1971 \text { Abdul Zahir } \\ 700007 & 700 & 12 & 1972 \text { Mohammad Musa Shafiq } \\ 700008 & 700 & 7 & 1973 \text { Sardar Mohammad Daud Khan } \\ 700009 & 700 & 4 & 1978 \text { Taraki } \\ 700010 & 700 & 3 & 1979 \text { Amin } \\ 700011 & 700 & 12 & 1979 \text { Karmal } \\ 700012 & 700 & 5 & 1986 \text { Najibullah } \\ 700013 & 700 & 4 & 1992 \text { Mojadidi } \\ 700014 & 700 & 6 & 1992 \text { Burhanuddin Rabbani } \\ 700015 & 700 & 9 & 1996 \text { Mullah Omar } \\ 700016 & 700 & 12 & 2001 \text { Hamid Karzai } \\ 700017 & 700 & 9 & 2014 \text { Ashraf Ghani } \\ 701001 & 701 & 10 & 1990 \text { Niyazov } \\ 701002 & 701 & 12 & 2006 \text { Berdymukhammedov } \\ 702001 & 702 & 8 & 1991 \text { Kadreddin Aslonov } \\ 702002 & 702 & 9 & 1991 \text { Nabiyev } \\ 702003 & 702 & 9 & 1992 \text { Iskandrov } \\ 702004 & 702 & 11 & 1992 \text { Rakhmonov } \\ 703001 & 703 & 10 & 1990 \text { Akayev } \\ 703002 & 703 & 4 & 2005 \text { Bakiyev } \\ 703003 & 703 & 4 & 2010 \text { Otunbayeva } \\ 703004 & 703 & 12 & 2011 \text { Atambayev } \\ 704001 & 704 & 3 & 1990 \text { Karimov } \\ 705001 & 705 & 4 & 1990 \text { Nazarbaev } \\ 710001 & 710 & 10 & 1976 \text { Hua Guofeng } \\ 710002 & 710 & 9 & 1980 \text { Deng Xiaoping } \\ 710003 & 710 & 2 & 1997 \text { Jiang Zemin } \\ 710004 & 710 & 3 & 2003 \text { Hu Jintao } \\ 710005 & 710 & 11 & 2012 \text { Xi Jinping } \\ 712001 & 712 & 1 & 1952 \text { Tsedenbal } \\ 712002 & 712 & 8 & 1984 \text { Batmonkh } \\ 712003 & 712 & 3 & 1990 \text { Ochirbat } \\ 731001 & 731 & 7 & 1994 \text { Kim Jong-lll } \\ 731002 & 731 & 12 & 2011 \text { Kim Jong Un } \\ 732001 & 732 & 5 & 1961 \text { Chang Do Yong } \\ 732002 & 732 & 7 & 1961 \text { Hee Park } \\ 732003 & 732 & 10 & 1979 \text { Choi Kuy Hay } \\ 732004 & 732 & 8 & 1980 \text { Park Choong Hoon } \\ 732005 & 732 & 8 & 1980 \text { Chun Doo Hwan } \\ 760001 & 760 & 3 & 1952 \text { Wangchuk, Jigme Dorji } \\ 760002 & 760 & 7 & 1972 \text { Wangchuck, Jigme Singye } \\ 760003 & 760 & 7 & 1998 \text { Lyonpo Jigme Thinley } \\ 760004 & 760 & 7 & 1999 \text { Lyonpo Sangay Ngedup } \\ 760005 & 760 & 7 & 2000 \text { Lyonpo Yeshey Zimba } \\ 760006 & 760 & 8 & 2001 \text { Lyonpo Khandu Wangchuk } \\ 760007 & 760 & 8 & 2002 \text { Lyonpo Kinzang Dorji } \\ 760008 & 760 & 8 & 2003 \text { Lyonpo Jigme Thinley } \\ 760009 & 760 & 8 & 2004 \text { Lyonpo Yeshey Zimba } \\ 760010 & 760 & 9 & 2005 \text { Lyonpo Sangay Ngedup } \\ 760011 & 760 & 9 & 2006 \text { Lyonpo Khandu Wangchuk } \\ 760012 & 760 & 7 & 2007 \text { Lyonpo Kinzang Dorji } \\ 770001 & 770 & 10 & 1951 \text { Nazimuddin } \\ & & & \end{array}$

1967 Regular Election/Selection 1967 Regular Election/Selection 1971 Regular Election/Selection 1972 Regular Election/Selection 1973 Regular Election/Selection 1978 Regime-Change Coup 1979 Regime-Change Co 1979 Reshuffle Coup 1986 Foreign Installation 1992 Foreign Installation 1992 Successful Rebellion 1996 First Election/Selection 2001 Successful Rebellion 2014 Foreign Installation First Election/Selection Rert Election/Selection 1991 First Election/Selection 1992 Forced Election/Selection 1992 Forced Electio/section First Election/Selection 2005 First Election/Selection 2010 Forced Election/Selection 2011 Forced Election/Selection Regular Election/Selection Regular Election/Selection
First Election/Selection First Election/Selection

1980 First Election/Selection 1997 Regular Election/Selection 2003 Regular Election/Selection 2 Regular Election/Selection Regular Election/Selection 1984 Regular Election/Selectio 1990 Forced Election/Selection 1997 Regular Election/Selectio 2011 First Election/Selection Regular Election/Selectio 1961 Regime-Change Coup 1979 Reshuffle Coup

1980 Forced Election/Selection 1980 Forced Election/Selection 1988 First Election/Selection 1972 Regular Election/Selection 1998 Regular Election/Selection 1999 First Election/Selection 2000 Regular Election/Selection 2001 2001 Regular telection/selection 2003 Regur Election/Selection 2003 Regular llection/selection 2004 Regular Election/Selection 2005 Regular Election/Selection 2006 Regular Election/Selection 2007 Regular Election/Selection

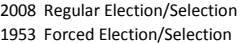

Resignation, Health Voluntary Resignation Regular Voluntary Resignation Regular Voluntary Resignation Regular Regime-Change Coup Regular $\begin{array}{ll}\text { Regime-Change Coup } & \text { Irregular } \\ \text { Reshuffle Coup } & \text { Irregular }\end{array}$ Foreign Overthrow Irregular Foreign Overthrow Irregular Rebellion Irregular Voluntary Resignation Irregular Rebellion Regular Foreign Overthrow Irregular Voluntary Resignation Still in Power Natural Death Still in Power Legal Remova Rebellion

Voluntary Resignation Regular
Irregular Sill in Power Regular Protest Regular Regular Still in Power $\quad$ Regular Still in Power Regular $\begin{array}{ll}\text { Still in Power } & \text { Regular } \\ \text { Voluntary Resignation } & \text { Regular }\end{array}$ Voluntary Resignation Regular $\begin{array}{ll}\text { Natural Death } & \text { Regular } \\ \text { Voluntary Resignation } & \text { Regular }\end{array}$ $\begin{array}{ll}\text { Voluntary Resignation } & \text { Regular } \\ \text { Voluntary Resignation } & \text { Regular }\end{array}$ Still in Power Regular Foreign Overthrow Regular Voluntary Resignation Regular Voluntary Resignation Natural Death Still in Power Reshuffle Coup Assassination Protest

Voluntary Resignation Voluntary Resignation Natural Death

$\begin{array}{ll}\text { th } & \text { Regular } \\ \text { Resignation } & \text { Regular }\end{array}$ Regular Volut Voluntary Resignation Regular Voluntary Resignation - Regul Voluntary Resignation Regur Voluntary Resignation Regular Voluntary Resignation Regular Voluntary Resignation Regular Voluntary Resignation Regular Voluntary Resignation Regular Voluntary Resignation Regular Voluntary Resignation Regular
Retired Due to III Health

Regular

Regular

Military Coup

Military Coup

Removed by Other Government Actors

Removed by Other Government Actors

Foreign
Rebellion

Rebellion

Regular

Rebellion

Rebellion

Regular

Still in Office

Natural Death

Still in Office

Regular

Rebellion
Regular

Regular

Regular
Protest

Protest

Protest

Regular

Still in Office

Still in Office

Still in Office

Regular

Natural Death

Regular

Regular

Foreign

Regular

Regular

Natural Death

Still in Office

Removed by Military Power Struggle

Removed by Other Government Actors

Regular

Regular

Natural Death

Regular

Regular

Regular

Regular

Regular

Regular

Regular

Regular

Regular

Regular

Regular

Regula

Regular 


\begin{tabular}{|c|c|c|c|}
\hline 770002 & 770 & 4 & 1953 Mohammed Ali \\
\hline 770003 & 770 & 8 & 1955 Chaudhri M. Ali \\
\hline 770004 & 770 & 9 & 1956 Shahid Suhrawardy \\
\hline 770005 & 770 & 10 & 1957 Chundrigar \\
\hline 770006 & 770 & 12 & 1957 Khan Noon \\
\hline 770007 & 770 & 10 & 1958 Ayub Khan \\
\hline 770008 & 770 & 3 & 1969 Yahya Khan \\
\hline 770009 & 770 & 7 & 1977 Zia \\
\hline 770010 & 770 & 8 & 1988 Ishaq Khan \\
\hline 770011 & 770 & 10 & 1999 Musharraf \\
\hline 771001 & 771 & 4 & 1971 Syed Nazrul Islam \\
\hline 771002 & 771 & 1 & 1972 Sheikh Mujib Rahman \\
\hline 771003 & 771 & 8 & 1975 Moshtaque Ahmed \\
\hline 771004 & 771 & 11 & 1975 Ziaur Rahman \\
\hline 771005 & 771 & 5 & 1981 Sattar \\
\hline 771006 & 771 & 3 & 1982 Ershad \\
\hline 771007 & 771 & 1 & 2007 Fakhruddin \\
\hline 775001 & 775 & 10 & $1958 \mathrm{Ne}$ Win \\
\hline 775002 & 775 & 3 & 1962 Ne Win \\
\hline 775003 & 775 & 7 & 1988 Sein Lwin \\
\hline 775004 & 775 & 8 & 1988 Maung Maung \\
\hline 775005 & 775 & 9 & 1988 Saw Maung \\
\hline 775006 & 775 & 4 & 1992 Than Shwe \\
\hline 775007 & 775 & 3 & 2011 Thein Sein \\
\hline 775008 & 775 & 3 & 2016 Htin Kyaw \\
\hline 780001 & 780 & 1 & 1989 Premadasa \\
\hline 780002 & 780 & 5 & 1993 Wijetunge \\
\hline 781001 & 781 & 7 & 1965 Nasir \\
\hline 781002 & 781 & 11 & 1978 Gayoom \\
\hline 790001 & 790 & 2 & 1951 Tribhuvan \\
\hline 790002 & 790 & 3 & 1955 Mahendra \\
\hline 790003 & 790 & 1 & 1972 Birendra \\
\hline 790004 & 790 & 11 & 1990 Krishna Prasad Bhatterai \\
\hline 790005 & 790 & 10 & 2002 Lokendra Bahadur Chand \\
\hline 790006 & 790 & 6 & 2003 Surya Bahadur Thapa \\
\hline 790007 & 790 & 6 & 2004 Sher Bahdur Deuba \\
\hline 790008 & 790 & 2 & 2005 Gyanendra \\
\hline 800001 & 800 & 9 & 1957 Pote Sarasin \\
\hline 800002 & 800 & 12 & 1957 Thanon Kittakachorn \\
\hline 800003 & 800 & 10 & 1958 Sarit \\
\hline 800004 & 800 & 12 & 1963 Thanon Kittakachorn \\
\hline 800005 & 800 & 10 & 1973 Sanya \\
\hline 800006 & 800 & 2 & 1975 Seni Pramoj \\
\hline 800007 & 800 & 10 & 1976 Thanin Kraivichien \\
\hline 800008 & 800 & 10 & 1977 Sangad \\
\hline 800009 & 800 & 11 & 1977 Kriangsak \\
\hline 800010 & 800 & 3 & 1980 Prem \\
\hline 800011 & 800 & 3 & 1991 Panyarachun \\
\hline 800012 & 800 & 4 & 1992 Kraprayoon \\
\hline 800013 & 800 & 9 & 2006 Chulanont \\
\hline 800014 & 800 & 5 & 2014 Prayuth Chan-ocha \\
\hline 811001 & 811 & 11 & 1953 Sihanouk \\
\hline 811002 & 811 & 3 & 1970 Lon Nol \\
\hline 811003 & 811 & 4 & 1975 Pol Pot \\
\hline 811004 & 811 & 1 & 1979 Heng Samrin \\
\hline
\end{tabular}

1955 Regular Election/Selection 1956 Regular Election/Selection 1957 Regular Election/Selection (957 Regular Election/Selection 1958 Regular Election/Selection 1969 Regime-Change Coup 1971 Forced Election/Selection 1988 Regime-Change Coup 1988 Forced Election/Selection 2008 Regime-Change Coup 1972 First Election/Selection 1975 Regular Election/Selection 1975 Regime-Change Coup 1981 Reshuffle Coup 1982 Forced Election/Selection 1990 Regime-Change Coup 2009 Forced Election/Selection 1960 Forced Election/Selection 1988 Regime-Change Coup 1988 Forced Election/selection 1988 Forced Election/Selection 1992 Regime-Change Coup 2011 First Election/Selection 2016 Regular Election/Selection Regular Election/Selection 1993 Regular Election/Selection 1994 Forced Election/Selection 1978 First Election/Selection 2008 Regular Election/Selection 1955 Successful Rebellion 1972 First Election/Selection 1990 Regular Election/Selectio 1991 First Election/Selection 2003 Forced Election/Selection 2004 Forced Election/Selection 2005 Forced Election/Selection 2006 Forced Election/Selection 1957 Reshuffle Coup 1958 First Election/Selection 1963 Regular Election/Selection 1973 Regular Election/Selectio 1975 Successful Protest 1975 Regular Election/Selection 1975 Regular Election/Se 1977 Reshuffle Coup 1980 First Election/Selection 1988 Regular Election/Selection 1992 Regime-Change Coup 1992 First Election/Selection 2008 Reshuffle Coup Regime-Change Coup 1970 First Election/Selection 1975 Regime-Change Coup 1979 Successful Rebellion
Voluntary Resignation Regular Voluntary Resignation Regular Voluntary Resignation Regular Voluntary Resignation Regula Regime-Change Coup Regular Protest Regime-Change Coup Irregular Assassination Irregular Voluntary Resignation Regular Voluntary Resignation Irregular Voluntary Resignation Regular Regime-Change Coup Regu Reshuffle Coup Irregular Assassination Irregula Regime-Change Coup Regular Protest

Regime-Change Coup Regular Voluntary Resignation Regular Protest Irregular Protest Irregular Regular Irregular Voluntary Resignation Regular Still in Power Still in Power Nassination Voluntary Resignation Regular $\begin{array}{ll}\text { Voluntary Resignation } & \text { Regular } \\ \text { Voluntary Resignation } & \text { Regular }\end{array}$ Voluntary Resignation Regular $\begin{array}{ll}\text { Voluntary Resignation } & \text { Regular } \\ \text { Natural Death } & \text { Irregula }\end{array}$ Natural Death Irregular Natural Death $\quad$ Regular Voluntary Resignation Regular Voluntary Resignation Regular Protest Regular Protest Regular Legal Removal Regular Rebellion Regular Voluntary Resignation Irregula Voluntary Resignation Regular Natural Death Irregular Protest Voluntary Resignation Regular Reshuffle Coup Regular Reshuffle Coup Regular Voluntary Resignation Irregular Voluntary Resignation Irregular Volutary Resignation Irregular Voluntary Resignation Regular Protest Regular Protes Voluntary Resignation Regular Still in Power Irregular Regime-Change Coup Regular $\begin{array}{ll}\text { Rebellion } & \text { Irregular } \\ \text { Foreign Overthrow } & \text { Irregular }\end{array}$ $\begin{array}{ll}\text { Foreign Overthrow } & \text { Irregular } \\ \text { Voluntary Resignation } & \text { Regular }\end{array}$
Regular

Regular

Regular

Removed by Other Government Actors

Protest

Military Coup

Irregular, Other

Regular

Regular

Regular

Military Coup

Military Coup

Military Coup

Military Coup

Protest

Regular

Regula

Regular

Military Coup

Retired Due to III Health

Regular

Still in Office

NA

Irregular, Other

Regular

Retired Due to III Health

Regular

Natural Death

Natural Death

Regular

Regular

Regular

Regular

Regular

Protest

Regular

Regular

Natural Death

Protest

Regular

Regular

Regular

Regular

Regular

Regular

Regular

Regular

Regular
Still in Office

Military Coup

Rebellion

Foreign
Regular 


\begin{tabular}{|c|c|c|c|}
\hline 811005 & 811 & 1 & 1985 Hun Sen \\
\hline 811006 & 811 & 9 & 1993 Ranariddh \\
\hline 811007 & 811 & 7 & 1997 Hun Sen \\
\hline 812001 & 812 & 12 & 1959 Nosavan \\
\hline 812002 & 812 & 1 & 1960 Kou Abhay Og Long \\
\hline 812003 & 812 & 5 & 1960 Somsanith \\
\hline 812004 & 812 & 8 & 1960 Souvanna Phouma \\
\hline 812005 & 812 & 12 & 1960 Boun Oum \\
\hline 812006 & 812 & 6 & 1962 Souvanna Phouma \\
\hline 812007 & 812 & 4 & 1964 Souvanna Phouma \\
\hline 812008 & 812 & 12 & 1975 Phomivan \\
\hline 812009 & 812 & 11 & 1992 Phounsavanh \\
\hline 812010 & 812 & 2 & 1998 Siphandon \\
\hline 812011 & 812 & 6 & 2006 Sayasone \\
\hline 812012 & 812 & 4 & 2016 Vorachith \\
\hline 816001 & 816 & 9 & 1969 Le Duan \\
\hline 816002 & 816 & 7 & 1986 Truong Chinh \\
\hline 816003 & 816 & 12 & 1986 Nguyen Van Linh \\
\hline 816004 & 816 & 6 & 1991 Do Muoi \\
\hline 816005 & 816 & 12 & 1997 Phieu \\
\hline 816006 & 816 & 4 & 2001 Nong Duc Manh \\
\hline 816007 & 816 & 1 & 2011 Phu Trong \\
\hline 817001 & 817 & 1 & 1954 Pham Buu Loc \\
\hline 817002 & 817 & 6 & 1954 Quat \\
\hline 817003 & 817 & 6 & 1954 Ngo Dinh Diem \\
\hline 817004 & 817 & 11 & 1963 Minh \\
\hline 817005 & 817 & 1 & 1964 Khanh \\
\hline 817006 & 817 & 11 & 1964 Van Huong \\
\hline 817007 & 817 & 1 & 1965 Khahn \\
\hline 817008 & 817 & 2 & 1965 Quat \\
\hline 817009 & 817 & 6 & 1965 Van Thieu \\
\hline 820001 & 820 & 8 & 1957 Rahman \\
\hline 820002 & 820 & 4 & 1959 Razak \\
\hline 820003 & 820 & 8 & 1959 Rahman \\
\hline 820004 & 820 & 9 & 1970 Razak \\
\hline 820005 & 820 & 1 & 1976 Hussein Bin Onn \\
\hline 820006 & 820 & 7 & 1981 Mahatir Bin Mohammad \\
\hline 820007 & 820 & 10 & 2003 Ahmad Badawi \\
\hline 820008 & 820 & 4 & 2009 Najib Tun Razak \\
\hline 830001 & 830 & 8 & 1965 Lee Kuan Yew \\
\hline 830002 & 830 & 11 & 1990 Goh Chok Tong \\
\hline 830003 & 830 & 8 & 2004 Lee Hsien Loong \\
\hline 835001 & 835 & 10 & 1967 Hassanal Bolkiah \\
\hline 850001 & 850 & 3 & 1966 Suharto \\
\hline 850002 & 850 & 5 & 1998 Habibie \\
\hline 950001 & 950 & 10 & 1970 Mara \\
\hline 950002 & 950 & 5 & 1987 Rabuka \\
\hline 950003 & 950 & 12 & 1987 Mara \\
\hline 950004 & 950 & 6 & 1992 Rabuka \\
\hline 950005 & 950 & 5 & 2000 Bainimarama \\
\hline 950006 & 950 & 7 & 2000 Laisenia Qarase \\
\hline 950007 & 950 & 12 & 2006 Senilagakali \\
\hline 950008 & 950 & 1 & 2007 Bainimarama \\
\hline 955001 & 955 & 6 & 1970 Tu'ipelehake \\
\hline 955002 & 955 & 8 & 1991 Vaea \\
\hline
\end{tabular}

\begin{tabular}{|c|c|c|c|}
\hline & & Voluntary Resignation & Regular \\
\hline & Regular Election/Selection & Reshuffle Coup & Regular \\
\hline & Reshuffle Coup & Still in Power & Regular \\
\hline 1960 & Reshuffle Coup & Voluntary Resignation & Irregular \\
\hline 1960 & Forced Election/Selection & Voluntary Resignation & Irregular \\
\hline 1960 & Regular Election/Selection & Reshuffle Coup & Irregular \\
\hline 1960 & Reshuffle Coup & Reshuffle Coup & Irregular \\
\hline 1962 & Reshuffle Coup & Voluntary Resignation & Irregular \\
\hline 1964 & Regular Election/Selection & Reshuffle Coup & Irregular \\
\hline 1975 & Forced Election/Selection & Rebellion & Regular \\
\hline 1992 & Successful Rebellion & Natural Death & Irregular \\
\hline 1998 & Regular Election/Selection & Voluntary Resignation & Regular \\
\hline 2006 & Regular Election/Selection & Voluntary Resignation & Regular \\
\hline 2016 & Regular Election/Selection & Voluntary Resignation & Regular \\
\hline & Regular Election/Selection & Still in Power & NA \\
\hline 1986 & First Election/Selection & Natural Death & Regular \\
\hline 1986 & Regular Election/Selection & Voluntary Resignation & Regular \\
\hline 1991 & Regular Election/Selection & Voluntary Resignation & Regular \\
\hline 1997 & Regular Election/Selection & Voluntary Resignation & Regular \\
\hline 2001 & Regular Election/Selection & Voluntary Resignation & Regular \\
\hline 2011 & Regular Election/Selection & Voluntary Resignation & Regular \\
\hline & Regular Election/Selection & Still in Power & Regular \\
\hline 1954 & Regular Election/Selection & Voluntary Resignation & Regular \\
\hline 1954 & Regular Election/Selection & Voluntary Resignation & Regular \\
\hline 1963 & Regular Election/Selection & Reshuffle Coup & Irregular \\
\hline 1964 & Reshuffle Coup & Reshuffle Coup & Irregular \\
\hline 1964 & Reshuffle Coup & Voluntary Resignation & Irregular \\
\hline 1965 & First Election/Selection & Reshuffle Coup & Irregular \\
\hline 1965 & Reshuffle Coup & Legal Removal & Irregular \\
\hline 1965 & Forced Election/Selection & Reshuffle Coup & Irregular \\
\hline 1975 & Reshuffle Coup & Reshuffle Coup & Irregular \\
\hline 195 & First Election/Sel & Voluntary Resignation & Regular \\
\hline 1959 & Regular Election/Selection & Voluntary Resignation & Regular \\
\hline 1970 & Regular Election/Selection & Legal Removal & Regular \\
\hline 1976 & Forced Election/Selection & Natural Death & Regular \\
\hline 198 & Regular Election/Selection & Resignation, Health & Regular \\
\hline 2003 & Regular Election/Selection & Voluntary Resignation & Regular \\
\hline 2009 & Regular Election/Selection & Voluntary Resignation & Regular \\
\hline & Regular Election/Selection & Still in Power & Regular \\
\hline 1990 & First Election/Selection & Voluntary Resignation & Regular \\
\hline 2004 & Regular Election/Selection & Voluntary Resignation & Regular \\
\hline & Regular Election/Selection & Still in Power & Regular \\
\hline & First Election/Selection & Still in Power & Regular \\
\hline 1998 & 3 Regime-Change Coup & Voluntary Resignation & Irregular \\
\hline 199 & First Election/Selection & Voluntary Resignation & Regular \\
\hline 1987 & First Election/Selection & Voluntary Resignation & Regular \\
\hline 198 & Reshuffle Coup & Voluntary Resignation & Irregular \\
\hline 1992 & Forced Election/Selecti & Voluntary Resignation & Regular \\
\hline 1999 & Regular Election/Selection & Voluntary Resignation & Regular \\
\hline 200 & Reshuffle Coup & Rebellion & Irregular \\
\hline 2006 & Successful Rebellion & Reshuffle Coup & Regular \\
\hline & Reshuffle Coup & Voluntary Resignation & Regular \\
\hline & First Election/Se & Still in Power & $\operatorname{Ir}$ \\
\hline & First Election/Selection & Voluntary Resignation & NA \\
\hline & Regular Election/Selecti & Voluntary Resignation & NA \\
\hline
\end{tabular}

Regular

Removed by Other Government Actors

Regula

Regular

Regular

Military Coup

Military Coup

Regular

Military Coup

Rebellion

Natural Death

Regular

Regular

Still in Office

NA

Natural Death

Regular

Regular

Regular

Regular

Regular

Still in Office

Regular

Military Coup

Military Coup

Military Coup
Protest

Military Coup

Removed by Military Power Struggle

Military Coup

Foreign

Regular

Regular

Regular

Natural Death

Retired Due to III Health

Regular

Regular

Still in Office

Regular

Regular
Still in Office

Still in Office

Regular

Regular

Regular

Regular

Regular

Regular

Regular

Removed by Other Government Actor

Military Coup

Regular

Still in Office

NA 


$\begin{array}{lrrl}955003 & 955 & 1 & 2000 \text { Ulukalala Lavaka Ata (Tupou VI) } \\ 955004 & 955 & 2 & 2006 \text { Sevele } \\ 955005 & 955 & 12 & 2010 \text { Tu'vakano } \\ 955006 & 955 & 12 & \text { 2014 Pohiva }\end{array}$

22006 Regular Election/Selection

$\begin{array}{lll}2006 \text { Regular Election/Selection } & \text { Voluntary Resignation } & \text { NA } \\ 2010 \text { Regular Election/Selection } & \text { Voluntary Resignation } & \text { NA } \\ 2014 \text { Reglar Election/selection } & \text { Voluntary Resignation } & \text { NA }\end{array}$

$\begin{array}{ll}\text { Voluntary Resignation } & \text { NA } \\ \text { Voluntary Resignation } & \text { NA }\end{array}$

$\begin{array}{lll}4 \text { Regular Election/Selection } & \text { Voluntary Resignation } & \text { NA } \\ \text { Regular Election/Selection } & \text { Still in Power } & \text { NA }\end{array}$

NA

NA

2014 Pohiva

NA

0
0
0
0 


\section{Supporting Appendix B: Additional Empirics}

In this section, we run multinomial logit models by recoding the natural death cases as censored cases as a robustness check. The results are consistent with the results reported in the main text and support our hypotheses. 
Table 7: Multinomial Logit Analysis of Manner of Losing Office in Dictatorships

\begin{tabular}{|c|c|c|c|c|}
\hline & \multicolumn{4}{|c|}{ Model 1} \\
\hline Dependent Variable & Coalition & Coalition & Coalition & Voluntary \\
\hline Exit Manner & Competing & Circumventing & Collapsing & Resignation \\
\hline \multicolumn{5}{|l|}{ Base Category } \\
\hline Entry Manner & \multicolumn{4}{|c|}{ Irregular Replacement Entry } \\
\hline \multicolumn{5}{|l|}{ Independent Variables } \\
\hline \multirow[t]{2}{*}{ Regular Entry } & $1.893 * * *$ & -1.810 & .312 & -.188 \\
\hline & $(.661)$ & ( 1.244$)$ & $(.446)$ & $(.504)$ \\
\hline \multirow[t]{2}{*}{ Regular $\times \log ($ Tenure $)$} & $-.514 *$ & .862 & -.361 & $.374 *$ \\
\hline & $(.273)$ & $(.626)$ & $(.265)$ & $(.224)$ \\
\hline \multirow[t]{2}{*}{ Irregular Reorganization Entry } & $2.580 * * *$ & .430 & .356 & .488 \\
\hline & $(.535)$ & $(1.020)$ & $(.533)$ & $(.466)$ \\
\hline \multirow[t]{2}{*}{ Reorganization $\times \log ($ Tenure $)$} & $-.778 * * *$ & .206 & .422 & .106 \\
\hline & $(.286)$ & $(.718)$ & $(.310)$ & $(.266)$ \\
\hline \multirow[t]{2}{*}{ Foreign Entry } & .735 & -.051 & $-13.744 * * *$ & -2.637 \\
\hline & $(1.811)$ & $(.955)$ & $(.747)$ & $(2.291)$ \\
\hline \multirow[t]{2}{*}{ Foreign $\times \log ($ Tenure $)$} & .355 & .847 & $.774 *$ & $1.109 *$ \\
\hline & $(.853)$ & $(.673)$ & $(.422)$ & $(.661)$ \\
\hline \multirow[t]{2}{*}{ Log(Tenure) } & $.633 * * *$ & -.591 & $-.508 * *$ & $-.453 * *$ \\
\hline & $(.204)$ & $(.441)$ & $(.221)$ & $(.213)$ \\
\hline \multicolumn{5}{|l|}{ Controls } \\
\hline \multirow[t]{2}{*}{$\ln (\mathrm{GDP} /$ capita $)$} & $-.352 * *$ & .028 & -.207 & .119 \\
\hline & $(.136)$ & $(.150)$ & $(.130)$ & $(.138)$ \\
\hline \multirow[t]{2}{*}{ GDP Growth } & $-3.237 * * *$ & -1.802 & -.172 & -.542 \\
\hline & $(.867)$ & $(1.687)$ & $(.601)$ & $(.777)$ \\
\hline \multirow[t]{2}{*}{ Military Dictatorship } & -.083 & .250 & $.714 * *$ & $.658 * * *$ \\
\hline & $(.300)$ & $(.501)$ & $(.340)$ & $(.251)$ \\
\hline \multirow[t]{2}{*}{ Monarchy } & $-2.105^{* * *}$ & -.520 & -.389 & -.804 \\
\hline & $(.797)$ & $(.583)$ & $(.592)$ & $(.603)$ \\
\hline \multirow[t]{2}{*}{ Party } & $-2.055 * * *$ & -.424 & $-.737 * *$ & $1.060 * *$ \\
\hline & $(.398)$ & $(.547)$ & $(.339)$ & $(.428)$ \\
\hline \multirow[t]{2}{*}{ Ln(Military Personnel) } & $-.167 *$ & .077 & -.074 & .046 \\
\hline & $(.096)$ & $(.150)$ & $(.075)$ & $(.061)$ \\
\hline \multirow[t]{2}{*}{ Civil War } & $1.866 * * *$ & $.906^{*}$ & .395 & .255 \\
\hline & $(.274)$ & $(.473)$ & $(.346)$ & $(.232)$ \\
\hline \multirow[t]{2}{*}{ War Victory } & $-2.394 *$ & $-7.197 * *$ & -5.288 & -2.333 \\
\hline & ( 1.244$)$ & $(2.948)$ & (3.697) & ( 1.459$)$ \\
\hline \multirow[t]{2}{*}{ War Defeat } & $.955^{*}$ & $3.088 * * *$ & .528 & -.016 \\
\hline & $(.511)$ & $(.586)$ & $(.726)$ & (.689) \\
\hline \multirow[t]{2}{*}{ War Draw } & -.574 & -1.259 & -.818 & -.855 \\
\hline & $(.489)$ & $(1.032)$ & $(.627)$ & $(.660)$ \\
\hline \multirow[t]{2}{*}{ Age } & $.040 * * *$ & $.047 * *$ & $.025 * *$ & $.044 * * *$ \\
\hline & (.013) & $(.021)$ & $(.011)$ & $(.010)$ \\
\hline Constant & $-3.673 * * *$ & $-7.123 * * *$ & $-2.562 * * *$ & $-7.380 * * *$ \\
\hline & $(.943)$ & ( 1.331$)$ & $(.902)$ & $(.943)$ \\
\hline Log Likelihood & & & -1287.8 & \\
\hline Observations & & & 3613 & \\
\hline
\end{tabular}

$* p<0.10 ; * *<<0.05 ; * * * p<0.01$ (two-tailed). Robust standard errors are in parentheses clustered with country. 
Table 8: Multinomial Logit Analysis of Manner of Losing Office in Dictatorships

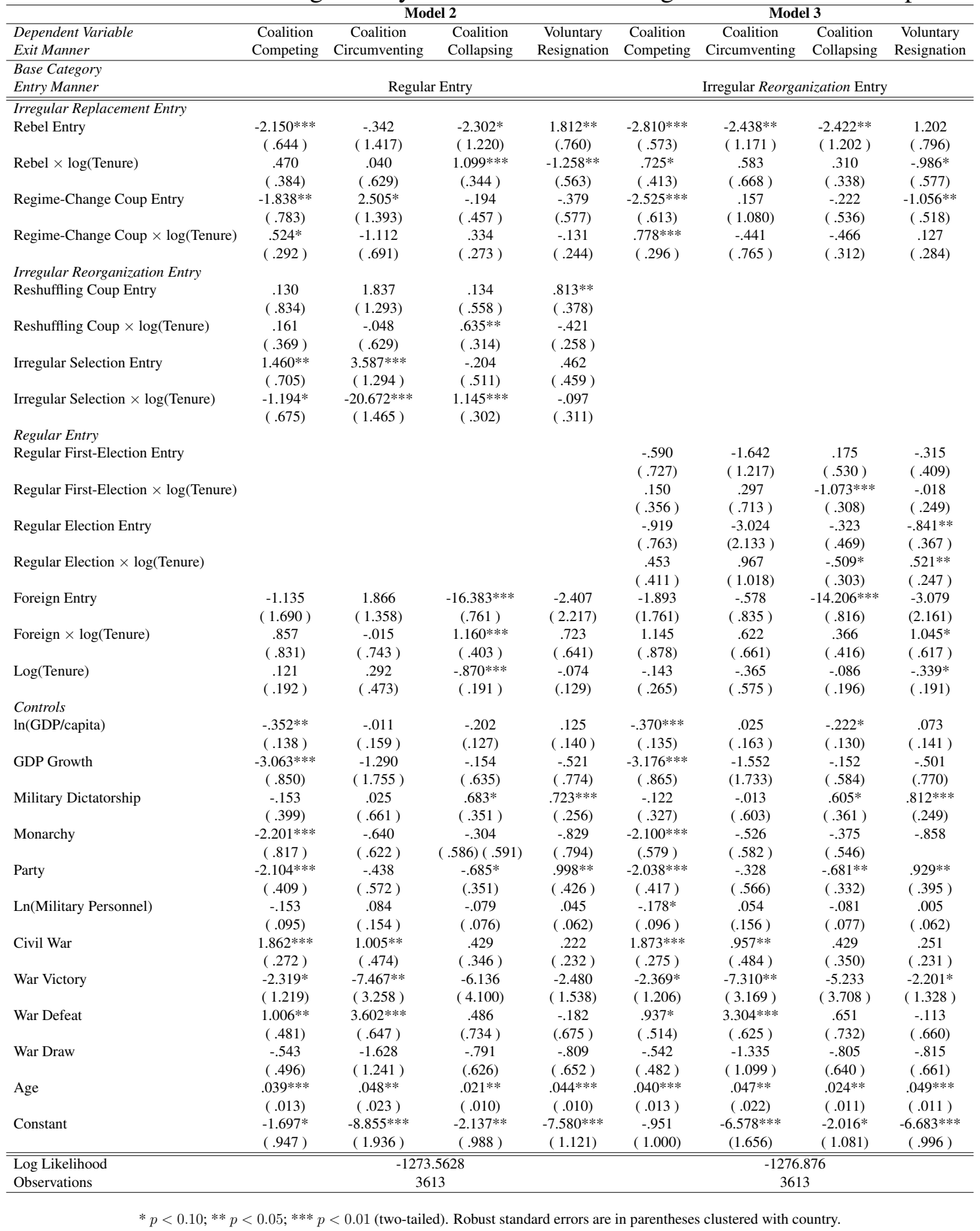




\section{Supporting Appendix C: Additional Figures}

Figure 6: Effect of Reshuffling-Coup, Forced Selection, First-Election and Regular-Election Entry on Coalition-Competing Removal
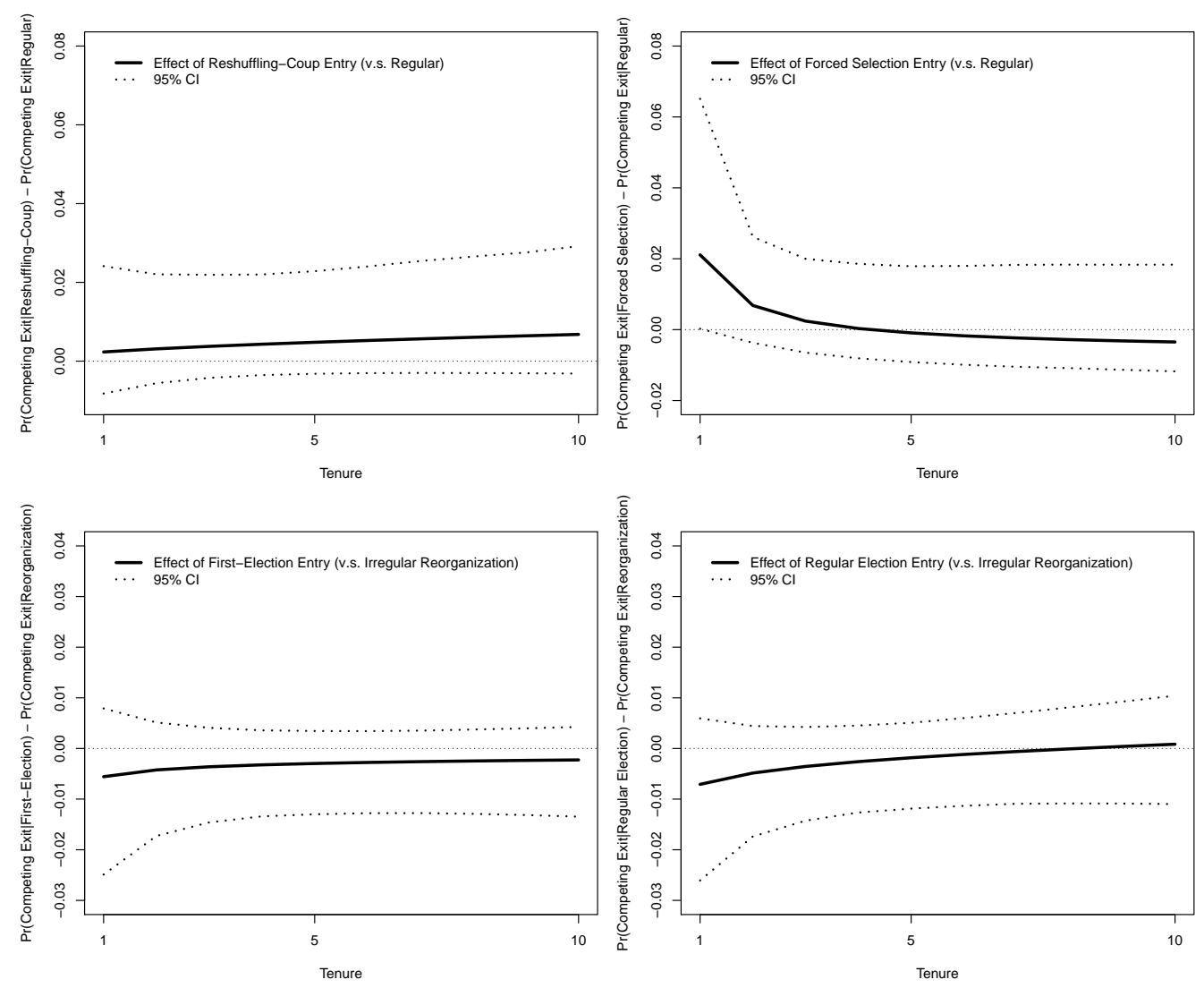

Note: We use Model 2 in Table 5 to estimate the first difference. 